Louisiana State University

LSU Digital Commons

1978

\title{
Stability of Induced Dna Alkylations in Sperm and Embryos of Drosophila Melanogaster.
}

Frank Charles Janca

Louisiana State University and Agricultural \& Mechanical College

Follow this and additional works at: https://digitalcommons.Isu.edu/gradschool_disstheses

\section{Recommended Citation}

Janca, Frank Charles, "Stability of Induced Dna Alkylations in Sperm and Embryos of Drosophila Melanogaster." (1978). LSU Historical Dissertations and Theses. 3241.

https://digitalcommons.Isu.edu/gradschool_disstheses/3241

This Dissertation is brought to you for free and open access by the Graduate School at LSU Digital Commons. It has been accepted for inclusion in LSU Historical Dissertations and Theses by an authorized administrator of LSU Digital Commons. For more information, please contact gradetd@lsu.edu. 


\title{
INFORMATION TO USERS
}

This material was produced from a microfilm copy of the original document. While the most advanced tachnological means to photograph and reproduce this document have been used, the quality is heavily dependent upon the quality of the original submittied.

The following explanation of techniques is provided to help you understand markings or patterns which may appear on this reproduction.

1. The sign or "target" for pages apparently lacking from the document photographed is "Missing Page(s)". If it was possible to obtain the missing page(s) or section, they are spliced into the film along with adjacent pages. This may have necessitated cutting thru an image and duplicating adjacent pages to insure you complete continuity.

2. When an image on the film is obliterated with a large round black mark, it is an indication that the photographer suspected that the copy may have moved during exposure and thus cause a blurred image. You will find a good image of the page in the adjacent frame.

3. When a map, drawing or chart, etc., was part of the material being photographed the photographer followed a definite method in "sectioning" the material. It is customary to begin photoing at the upper left hand corner of a large sheet and to continue photoing from left to right in equal sections with a small overlap. If necessery, sectioning is continued again - beginning below the first row and continuing on until complete.

4. The majority of users indicate that the toxtual content is of greatest value, however, a somewhat higher quality reproduction could be made from "photographs" if essential to the understending of the dissertation. Silver prints of "photographs" may be ordered at additional charge by writing the Order Department, giving the catalog number, title, author and spacific pages you wish reproduced.

5. PLEASE NOTE: Some pages may have indistinct print. Filmed received.

\author{
University Microfilms International \\ 300 North Zeeb Roed \\ Ann Arbor, Michigan 48106 USA \\ St. John's Road, Tyler's Green \\ High Wycombe, Bucks, England HP10 8HP
}


7903136

JANCA, FRANK CHARLES

STABILITY OF INDUCED DNA ALKYLATIONS IN SPERM

AND EMBRYOS OF DROSOPHILA MELANOGASTER.

THE LUUISIANA STATE UNIVERSITY AND

AGRICULTURAL AND YECHANICAL CQL. PH.D., 1978 
STABILITY OF INDUCED

DNA ALKYLATIONS IN SPERM AND EMBRYOS

OF DROSOPHILA MELANOGASTER

\author{
A Dissertation \\ Submitted to the Graduate Faculty of the \\ Louisiana State University and \\ Agricultural and Mechanical College \\ In partial fulfillment of the \\ requirements for the degree of \\ Doctor of Phflosophy \\ in
}

The Department of Zoology

by

Frank Charles Janca

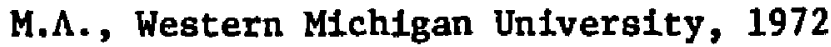

August 1978 


\section{ACKNOWLEDGMENTS}

I wish to thank my parents August and E1la Janca and my brother and slster, Gus and Darlene, for their continued love and support during this endeavor. I especlally want to thank Dr. Charles Sydney Aaron, Mrs. Helen Nardin, Mrs. Patricia Skinner and Mrs. Mary Martin Jones for the friendship, moral support and technical aid they provided.

I also wish to thank Drs. Hugh D. Braymer, Thomas H. Dietz, Wilbur L. French, William R. Lee, J. Harvey Roberts and John J. Willie, Jr. for serving on my Graduate Advisory Committee. I also want to thank the Department of Zoology at Louisiana State University and $\mathrm{Dr}$. William $\mathrm{R}$. Lee for providing the monetary support without which this work would not have been possible.

Finally, I would particularly like to thank Dr. William R. Lee for his patient guidance and instruction throughout the research and writing that went into this work. 
TABLE OF CONTENTS

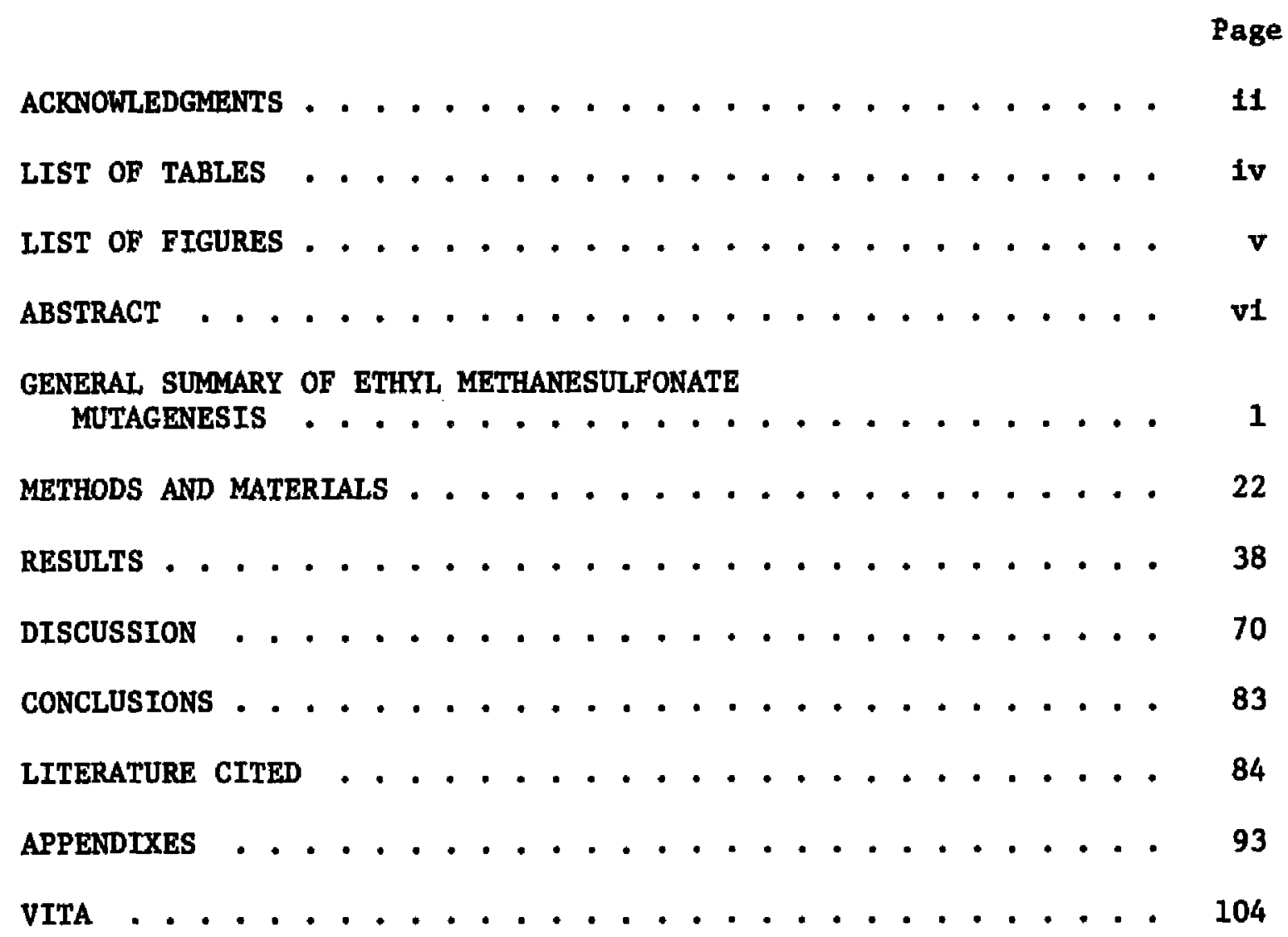


Table

I. The ${ }^{3} \mathrm{H} /{ }^{32} \mathrm{p}$ Ratios from Sperm and Embryo Samples from Six Different Experiments . . . . . . . . . . 39

II. Analysis of Vartance for ${ }^{3} \mathrm{H} /{ }^{32} \mathrm{P}$ Ratio in Sperm Cells and 180-Minute Embryos from Expertments 1 to 5. . . . . . . . . . . . . . . 42

III. The Analysis of Varlance for ${ }^{3} \mathrm{H} /{ }^{32} \mathrm{p}$ Ratlos from Experiment 6. .................. 45

IV. The ${ }^{3} \mathrm{H} /{ }^{32} \mathrm{P}$ Ratios from Stored and Non-Stored ${ }^{3} \mathrm{H}$-EMS Treated Drosophfla Spermatozoa ............ 46

V. The Calculated Rates for ${ }^{3} \mathrm{H} /{ }^{32} \mathrm{p}$ Reduction in Stored Sperm Cells ..................... . 51

VI. The Calculated Rates for ${ }^{3} \mathrm{H} /{ }^{32} \mathrm{P}$ Reduction in the Embryos During Early Cleavage and $T$-Test of the Rates . . . . . . . . . . . . . . . . . 54

VII. The Calculated Rates for ${ }^{3} \mathrm{H} /{ }^{32} \mathrm{P}$ Reduction in the Embryos During Later Stages and T-Test of the Rates . . . 57

VIII. The Egg Fert1lity Using Carbon Dloxide Gas to Induce Egg Layling . . . . . . . . . . . . . . . 62

IX. The Percentage of Embryos Retained Beyond the Stage Sampled

X. Verification of DNA Extraction Procedure and F-Test of Ratios ....................... 68 


\section{LIST OF FIGURES}

FIgure

Page

1. Mating scheme for the production of only

fertile CD male embryos. . . . . . . . . . . . . . 23

2. Mating scheme for the production of $Q$ virgins. . . . . . 25

3. Mating scheme for the production of wild-type automatic virgins. ............... 26

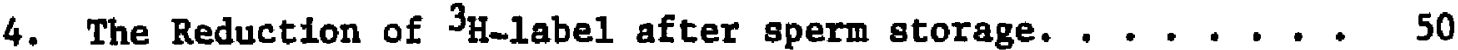

5. The reduction of ${ }^{3} \mathrm{H}$-label from sperm derived DNA during embryonic development ............ 53 


\section{ABSTRACT}

Treatment of Drosophila melanogaster spermatozoa with the alkylating agent ethyl methanesulfonate (EMS) Induces a high level of DNA ethylation, but Induces a comparatively low frequency of sex-1inked recessive lethal mutations. The induction of recessive mutations 16 germ cell stage specific with the highest frequencies being induced when late spermatids or mature spermatozoa are treated. A inigh frequency of these induced mutations are mosalc mutations which apparently are established during early embryonic cleavage. Storage of EMS treated sperm cells in the seminal receptacle for prolonged periods causes a time dependent shift in the mutation spectrum. This storage effect results in a time dependent increase in the frequency of those types of mutational events that are classed as chromosome aberrations. To understand these aspects of the mutational spectrum it is important to determine if alkylations induced in the DNA of sperm cells are retained throughout cleavage in the embryo. Retention of DNA alkylations was investigated by double labeling male Drosophila with ${ }^{32} \mathrm{P}$ and ${ }^{3} \mathrm{H}-\mathrm{EMS}$ and by comparing the ${ }^{3} \mathrm{H} /{ }^{32} \mathrm{P}$ ratios of DNA extracted from labeled sperm sampled at various times following EMS treatment with DNA extracted from embryos sampled throughout cleavage.

The $3_{\mathrm{H}} /{ }^{32} \mathrm{P}$ ratios from the sperm samples indicate that DNA alkylations are lost from sperm cells at a very slow rate and that this loss can be accounted for by the hydrolysis of alkylated bases (ethyl purines) from the ethylated DNA. Because of this slow loss many of the alkyl groups accumulated in the treated spermatozoa are retained until 


\section{fertilization.}

Comparison of the ${ }^{3} \mathrm{H} / 32 \mathrm{p}$ ratios of sperm cells and embryos suggests that there is a significant reduction of alkylation during early embryonic development prior to the first or second mitotic division. Th1s reduction during the early embryonic period cannot be accounted for by spontaneous hydrolytic loss of alkylated bases. After this early embryonic period alkyl groups continue to be lost but the rate of loss in these later embryonic stages is not significantly greater than the rate for hydrolytic depurination of alkylated DNA. Some alkyl groups are retained throughout early cleavage and are detected In the gastrula which is the latest embryonic stage sampled. 
GENERAL SUMMARY OF ETHYL METHANESULFONATE MUTAGENESIS

Ethyl methanesulfonate (EMS) is a powerful mutagen for a wide varlety of prokaryotic and eukaryotic organisms. EMS has been shown to induce varfous types of mutations, but the exact spectrum of mutatIons Induced depends on the organism, tissue, and cell stage treated.

\section{Prokaryotes}

In bacterla and bacteriophage, EMS Induces forward and reverse mutatIons (Loveless and Howarth, 1959; Strauss, 1961; Yanofsky et a1., 1966) and apparently Induces a high frequency of transitional type mutations (mutations involving base pair substitutions where a purine is exchanged for another purine or a pyrimidine is exchanged for another pyrimidine). Krelg (1963) induced EMS revertants in r11 T4 bacterfophage mutants. The mutants used in this investigation were produced by mutagenlc agents which cause specific types of DNA changes. Based on the types of mutants reverted Kreig concluded that the mafority of EMS induced mutations in phage result from transitions of $G: C \rightarrow A: T$, whereas a smaller portion are due to $A: T \rightarrow G: C$ transitions. Krefg also observed that EMS reverts proflavin Induced frameshift mutations (mutations which result from addition or deletion of a single base pair in the DNA), and concluded that in addition to inducing transitions, EMS could induce single base palr deletions which result in frameshift mutations. Tessman et al., (1964) treated host-range mutants of the single-stranded DNA phages S13 and $\varnothing \times 174$ with EMS and observed that guanine sites underwent transitional type changes more 
frequently than did adenine sites. These authors also observed that In the single-stranded DNA the pyrimidine sites seemed to be mutated about as frequently as the complementary purine sites. Yanofsky et al. (1966) studied amino acid replacement in EMS Induced revertants of tryptophan synthetase mutant strains of Escherichia coli. Observing that the majorlty of reversions involved aingle amino acid replacement the authors concluded that these amino acid replacements were most 11kely the result of single-base pair changes of the transition types.

Fung1 and Eukaryotic Plants

Results similar to those obtained with E. coli were observed when the fungus Neurospora crassa was treated with EMS. Malling and de Serres (1968) found among 76 mutants Induced at the Adenine-3b locus, $58 \%$ were transition mutations involving either $\mathrm{G}: \mathrm{C} \longrightarrow \mathrm{A}: \mathrm{T}$ or $\mathrm{A}: \mathrm{T} \longrightarrow \mathrm{G}: \mathrm{C}$ base changes; $9 \%$ were frameshift mutations Involving single-base paIr insertions or deletfons; and $7 \%$ were considered to have involved more extensive intragentc deletions.

EMS induced both single locus mutations and chromosome aberrations in higher plants. Rao and Natarajan (1963) reporting the results of EMS seed treatment in barley (Hordeum vulgare L.) found that seed treatment resulted in an increased frequency of cytologically detectable chromosome aberrations (chromosome breaks, dicentric chromosomes and chromatid exchanges) in both mitotic root tip cells and meiotic pollen mother cells. The resulting $M_{1}$ (f1rst generation) plants had an increased frequency of chlorophyll deficient chimeras which resulted from the induction of somatic chloroplyll mutations and exhibitted a reduction in pollen and seed fertility. The $M_{2}$ (second generation) 
plants resulting from EMS established lines were observed to have increased frequencies of visible mutations.

Ficsor (1965) treated Zea mays pollen with an EMS-mineral o11 suspension and observed the Induction of specific locus endosperm mutations Involving three closely linked phenotypically distingulshable genes. The majority of these mutations Involved simultaneous 1088 of all three genetIc markers; however, a few of the endosperm mutants did involve single-gene mutations. EMS pollen treatment also increased the frequency of dominant effects (slow growth and pollen sterility) in the $F_{1}$ plants. Based on the multiple loss of endosperm markers and the occurance of dominant effects Ficsor concluded that in maize pollen EMS induces most1y chromosome aberrations, but may be capable of Inducing some single-gene mutations. Amano and Smith (1965) treated both seeds and seedlings of Zea mays with aqueous solutions of EMS. They observed that the majority of mutants induced involved single locus mutations which could have resulted from elther single-base pair substitutions, single-base palr deletions or Intra-clstronic deletions of several base pairs. The apparent inconsistency between the results of Ficsor and those of Amano and Smith 18 probably due to the treatment of different tissue types. Ficsor treated pollen gametes while Amano and Smith treated somatic cells of the seed embryos and growing seedlings. Treatment of gametes (pollen) allows the detection of both chromosome aberrations and single locus mutations in the resulting endosperms and embryos. Induction of chromosome aberrations in somatic cells, however, can lead to immediate metabolic changes which affect cell viability and growth. As a result the treatment of somatic cells provides a very spectfic screen for genetic damage and allows only those mutations 
which do not significantly affect cell functions to be transmitted to the next generation. Bhatla (1967) reports that dimethyl sulfoxide exerts a synergistic effect with EMS In the Induction of albina (chlorophy11 deficient) mutants in the herb Arabidopsio thaliana.

\section{Drosophila}

EMS treatment of male Drosophila melanogaster Induces a high frequency of both visible and lethal recessive mutations, (Fahmy and Fahmy, 1957 and 1961; Alderson, 1965; Epler, 1966; JenkIns, 1967a and 1967b) but the increased mutation frequency is observed only in specific germcell stages. Fahmy and Fahmy (1957 and 1961) observed that three-day sequential matings (broods) of EMS-injected males produced elevated frequencles of visible and sex-linked recesstve lethal mutations only in those broods which result from spermatozoa that were treated during the post-meiotic stages. Jenkins (1967a and 1967b) also reported that EMS-Induced visible mutations are stage specific and that they occur with greatest frequency when post-meiotic cells (spermatid and spermatozoa) are treated.

Another aspect of the EMS mutational spectrum in Drosophila is that a high frequency of the mutations induced are mosalc mutations producing Individuals which contain both mutant and non-mutant cells (Jenkins, 1967a and 1967b; Epler, 1966; Alderson, 1965; Lee et al., 1970). Jenkins (1967a) observed that in $405 \mathrm{~F}_{1}$ EMS induced dumpy mutants $315(78 \%)$ were visibly mosaic and 90 (22\%) were visibly complete. Jenkins estimated that when correction was made for those mutants which were vistbly complete but gonadally mosalc the frequency of $\mathrm{F}_{1}$ mosafc mutants was approximately 98\%. Lee et a1. (1970) also observed a high frequency of EMS-induced mosalc yellow-body $\mathrm{F}_{1}$ mutants (86\%) 
and mosaic white-eye mutants (49\%). The observation that $51 \%$ of the white-eye mutants are completes 18 attributed to the finding that the nuclel of the eye Imaginal disc represent only a small sample of the original cleavage nucle1. Thus, mutant Individuals can be mosaic but if mutant nuclel are not included in the eye imaginal disc the mosaic Is not detected as a visible mutation in the $F_{1}$. Lee (1976) has combined data from several sources and estimates that among mutagen-induced visible-mosaic $F_{1}$ females $11 \%$ carry a mosaic germline; $13 \%$ carry a completely mutant germline and $76 \%$ carry a completely non-mutant germ1ine. This indicates that on the average mosalc embryos carry an induced mutation in only $1 / 4$ of their nucle1. Thus, as observed by Auerbach (1946) the flxation of these mosalc mutations does not occur Immedlately after treatment of the sperm cells but apparently is delayed until the first or second mitotic division in the embryo. Storage of EMS treated sperm cells in the seminal receptacle of the female causes a time dependent change in the mutation spectrum (Abrahamson et al., 1969; Srám, 1970a and 1970b; Schalet, 1977). Abrahamson et al. (1969) reported an increase in translocation frequency after 10-day storage of EMS treated sperm. Only $20 \mathrm{~F}_{1}$ cultures from the stored group were fertile and capable of being further tested for translocations. The number of translocations observed in the stored group (three translocations) Is not much greater than the number observed In the non-stored group (one translocation) and thus the difference between the stored and non-stored groups may not be statist1cally significant. However, the sharp drop in the fertility among the stored cultures could indicate an EMS storage effect. Srám (1970a) 
treated Drosophila males with EMS and compared the frequency of dominant lethals in seven sequential egg broods taken over a 12 day period. The frequency of dominant lethals shows a continual increase with storage time. Schalet (1977) examined four sequential broods of progeny derived from a group of EMS treated sperm cells stored over a 12 day pertod and observed that later broods derived from stored EMS treated sperm cells had higher frequencies of sex-chromosome losses than did the earlier broods. Thus, the 'storage effect' appears to be a time dependent Increase in the frequency of those types of mutational events (translocations, dominant lethals and sex-chromatin 1osses) that are classed as chromosome aberrations.

Aaron and Lee (1978) reported that exposure of Drosophila males to $25 \mathrm{mM}$ EMS Induced a dosage of $1.42 \times 10^{-2}$ ethylations per nucleotide in the sperm cells. This dose 18 equivalent to ethylation of $1.4 \%$ of the total nucleotides in the sperm cell or ethylation of about $7 \%$ of the guanines (Lee, 1976) most probably at the N-7 position. Paralle1 genetic tests of males treated at the same high dosage indicated that only $43 \%$ of the treated X-chromosomes carrled sex-linked recessive lethals (Aaron and Lee, 1978). Using data for dose and genetic response from treatments with high and low levels of exposure to ${ }^{3} \mathrm{H}-\mathrm{EMS}$ these authors have constructed a dose-response curve. The relative frequency of sex-1inked recessive lethals increases linearly with dosages ranging from $2.1 \times 10^{-4}$ to $1.42 \times 10^{-2}$ ethylations per nucleotide. This doseresponse curve does not exhibit a dose threshold in relation to mutation Induction and predicts that the dose of ethylation required to double the frequency of sex-1inked recessive lethals is $4 \times 10^{-5}$ ethylations per nucleotide. This is equivalent to requiring the ethylation of 
approximately 12,000 nucleotides for each doubling of mutation rate. Thus, it appears that ethylation of sperm cell DNA is not ver efficient In Inducing lethal mutations.

Mammalian Systems

Several groups of Investigators (Ehling et al., 1968; Cattanach et al., 1968; Generoso and Russe11, 1969; and Generoso et al., 1974) have reported that intraperitoneal (1.p.) injection of EMS Induces dominant lethal mutations in mice. In male mice the Induction of dominant lethal mutations 18 germ-cell stage specific. Cattanach et a1., (1968) found the greatest increases in dominant lethal frequencies among progeny of matings made 6-7 days after 1.p. Injection, where the sperm had been treated as mature spermatozoa in the epididymis and as late spermatids In the testes. Sega (1974) using radiolabeling techniques has been able to estimate more precisely the most sensitive stage for dominant lethal Induction. His data Indicated that the spermatozoa which gave the highest dominant lethal frequencies were mid-spermatids at the time of EMS treatment. Ehling et al., (1968) pointed out that dominant lethal mutations appeared to be Induced most frequently in those stages which were undergoing nuclear histone exchange (exchanges of lysine-rich for arginine-rich histones) and suggested that the germ cell sensitivity was due to metabolic changes in these post-spermatogonial cells. Sega (1974) has shown that the mid spermatids do not exhibit the unscheduled DNA synthesis seen in earlier stages in response to EMS alkylation. This implies that spermatids may have lost an ability to repalr DNA alkylation damage. Cattanach et a1., (1968) observed that the greatest frequency of translocations resulting from chromosome breakage after 1.p. injection occurred during the perfod in which the greatest frequencles of dominant lethal mutations were induced, suggesting that dominant 
lethal mutations are primarily due to chromosome breakage and the resulting rearrangement of the genetic materlal. Generoso et al. (1974) observed similar relations between stage of treatment and Induction of dominant lethal mutations and translocations following 1.p. Injectiong of EMS above $100 \mathrm{mg} / \mathrm{kg}$ body welght.

EMS has also been shown to produce mutations under In vitro conditions in mammalian tissue culture systems. Chu and Malling (1968) provided evidence that EMS-Induced specific locus mutations in isolated Chinese hamster cell mutant clones. These clones were either auxotrophic for L-glutamine ( $\mathrm{glu}^{-}$) or reslstant to 8-azaguanine (azgr). EMS significantly increased the reverse mutations at the glu locus and the forward and reverse mutations at the azg locus.

EMS Induced Alkylated DNA Products

Ethyl methanesulfonate belongs to the group of blologically active compounds designated alkylating agents. The blologlcal effects of these chemical agents have been attributed to their ability to alkylate cellular macromolecules (protein and nucleic acids) under phystological conditions (Drake, 1970; Loveless, 1966; Lawley, 1974a and 1974b). EMS Is a monofunctional alkylating agent which reacts blochemically to ethylate nucleophilic sites on the cellular macromolecules. The alkylating reaction between EMS and blological macromolecules has been described as a slightly modified bimolecular $\left(\mathrm{S}_{\mathrm{N}} 2\right)$ nucleophilic substitutIon (Lawley, 1974a; Osterman-Golkar, et al., 1970) and EMS has been designated an $S_{N} 1 / S_{N} 2$ type alkylating agent. The types of products formed when EMS reacts with the nucleic acids (DNA and RNA) are of particular interest since it is assumed that these products lead to promu- 
tagenic (events which require further modification to result in mutations) and mutagenic events (Lawley, 1974b; Strauss, et al., 1975; Verly, 1975). DNA has geveral sites which can react with EMS. Among these are the ring and amino nitrogens and keto oxygens of the bases and the oxygens of the phosphate groups which link the sugar components of the DWA backbone (Lawley and Brookes, 1963; Bannon and Verly, 1972; Sun and Singer, 1975).

Early investigations by Brookes and Lawley (1963) utflizing actd hydrolysis to separate ethylated DNA products Indfcated that under both in vitro and in vivo conditions the nitrogen positions were alkylated by EMS. Approximately $92 \%$ of the base ethylations occurred at the $\mathrm{N}-7$ position of guanine and $8 \%$ occurred at the N-3 position of adenine. Based on these results it was presumed that alkylation of the $\mathrm{N}-7$ position of guanine was the biologically significant event in relation to EMS Induced mutagenesis (Lawley and Brookes, 1961; Lawley, 1966).

Loveless (1969) suggested that the oxygens on the bases, particularly the 0-6 position of guanine, might also be alkylated in nucleic acids. Following this suggestion many investigators (Lawley and Thatcher, 1970; Lawley and Orr, 1970; Sun and Singer, 1975; Singer, 1976) found a significant proportion of total alkylations at the 0-6 position of guanine when nuclelc actds were trepted under both in vivo and In vitro conditions with various $S_{N} 1$ alkylating agents. $S_{N} 2$ Alkylating agents do not readily react with the 0-6 position of guanine posstbly because it is less nucleophilic than other avallable sites (Sun and Singer, 1975; Lawley, 1974b).

Sun and Singer (1975) investigated the alkylation products resulting from treatment of HeLa cell DNA with EMS under in vivo and In 
vitro conditions. Their methods Involved a serles of DNA degradation procedures. Utilizing a mild enzymatic digegtion at neutral pH they were able to show that in addition to alkylating the nitrogen positions EMS also alkylated the 0-6 pogition of guanine. The distribution of the ethylated DNA derivatives under thelr $\underline{\text { In }}$ vivo and In vitro conditions were similar. These investigators found that EMS ethylated nucleophilic base positions of DNA In the following order; 7-ethyl guanine (75-81\%)> 3-ethyl adenine (2.2-4.4\%) >1-ethy1 adenine; 7-ethy1 adenine (2\%) > 3-ethyl guanine; 3-ethyl cytosine; 06-ethyl guanine (1ess than $1 \%$ ). A substantial amount of the total alkylation (8-13\%) was 1solated as ethyl phosphate derivatives 1ndicating that many DNA phosphodiesters react with EMS to form deoxyribophosphotriesters. This is in agreement with observations made by other investigators (Lawley, 1974b; Bannon and Verly, 1972; Shooter, et al., $1974 \mathrm{a}$ and 1974b; Verly, 1974). Bannon and Verly (1972) reported that 15\% of the total EMS alkylation In DNA 18 in the form of ethylated DNA phosphates. Shooter et al., (1974b) observed that $15 \%$ of the EMS-induced alkylations in the RNA phage R17 was also in the form of phosphotriesters.

Mutagenic Effects of Alkylated DNA Products

Since 7-alkyldeoxyguanosines Ionize approximately 100 times faster than deoxyguanosine at $\mathrm{pH} 7.0$, it was suggested that mutations might arise if the ionization of tautomertc shifts caused pairing errors during DNA replication (Lawley and Brookes, 1961). Such events would be expected to cause transition type mutations. Genetic evidence from prokaryotes tends to support this hypothesis for the induction of mutations (Kreig, 1963; Tessman et al., 1964). The majority of mutatIons Induced by ethylation in prokaryotes are transitions and most of 
the transitions Involve base pair substitutions of $G: C \rightarrow A: T$ in the double stranded DNA (Kreig, 1963) and G $\rightarrow$ A in single-stranded DNA (Tessman et al., 1964).

Evidence from In vitro RNA polymerase systems using nucleotide templates that contain 7-methy1 guanine indicates that the alkylated guanylic acid pairs normally with cytosine and that it mispaired no more frequently with uracil than does unmodified guanylic acid (Ludlum, 1970; Gerchman and Ludlum, 1973). Thus, alkylation of the N-7 position of guanine does not appear to effect Its pairing properties and may not be the prime contributor of the transition mutations observed. Gerchman and Ludlum (1973) observed that use of polynucleotide templates containing $0^{6}$-methyl guanylic acid results in misincorporation of UMP or AMP Into the product co-polymer. Furthermore, the observation that cytosine (the normal pairing partner of guanine) does not block this misincorporation Indicated that cytosine is not a normal base pairing partner for the $0^{6}$-methyl guanylic acid and that $0^{6}$-alky1 guanylic acid may not have the same pairing properties as guanylic acid. Thus, alkylation of DNA sites which are less reactive to alkylating agents may actualiy be more important for the induction of transition mutations than alkylation of the N-7 position of guanine.

While alkylation of the $N-7$ position of guanine may not be an $1 \mathrm{~m}-$ portant direct cause of mutations it may play a significant role by Inducing promutagenic events which can be converted to mutagentc events. Lindahl and Nyberg (1972) have estimated that under normal physiological conditions ( $\mathrm{pH} 7.5 ; 37^{\circ} \mathrm{C}$ ) the rate constant for hydrolytic depurination of non-alkylated native DNA is $3 \times 10^{-11} \mathrm{sec}^{-1}\left(1.8 \times 10^{-9} \mathrm{~min}^{-1}\right)$. Brookes and Lawley (1963) have calculated that the rate constants for 
hydrolysis of $\mathrm{N}-7$ methylated and $\mathrm{N}-7$ ethylated deoxyguanylic acid in aqueous solutions are $7 \times 10^{-4} \mathrm{~min}^{-1}$ and $6 \times 10^{-4} \mathrm{~min}^{-1}$, respectively. Lawley (1975) estimated that In DNA at $\mathrm{pH} 7.0$ the ha1f-11fe for 7methyl guanine is $150 \mathrm{hrs}$ and the half-life for 3-methyl adenine is 30 hrs. Using these estimates strauss et al., (1975) has calculated that the hydrolysis constants for loss of 7-methyl guanine and 3-methyl adenine from alkylated DNA are $7.7 \times 10^{-5} \mathrm{mln}^{-1}$ and $3.8 \times 10^{-4} \mathrm{mln}^{-1}$, respectively. Assuming the sites of the major reaction products 7methyl guanine and 3-methyl adenine are the most frequently depurinated sites, Strauss et al., (1975) calculate that the overall rate constant for depurination is $1.84 \times 10^{-4} \mathrm{~min}^{-1}$. Since the ethylated reaction products are slightly more stable than the methylated products (Strauss and Hill, 1970) the hydrolysis rates for 7-ethy1 guanine and 3-ethyl adenine and the over all depurination rate of these major EMS reaction products from DNA should be slightly slower than those for the methylated products. However, assuming their rate constants have the same order of magnitude as those of the methylated bases, the over all depurination rate for the ethylated products should be substantially larger than that calculated for non-alkylated native DNA.

A number of potentially mutagenic events could occur if apurinic DNA sttes persist to the S-phase of the cell cycle. Apurinic sites might be ignored during DNA synthesis resulting in base pair deletions, and/or frameshift mutations. Alternately, the DNA systhesizing mechanism may select a base at random and insert it into the new DNA strand at the point opposite the apurinic site in the template strand (Fishbein et al., 1970). This event could lead to base patr substitution of efther transition or transversion type. Depurination leaves an unstable 
deoxyribose residue which can undergo spontaneous or enzymatic hydrolyols and result in single-strand breakage of the DNA chain (Lindahl and Anderson, 1972). In vivo DNA apurinlc sites are converted to singlestrand breaks by endonucleases which are speciflc for apurinic sites (Verly, 1975; Strauss et al., 1975; K1rt1kar and Goldthwalt, 1974). Such lestons if left unaltered could be converted to chromosome aberrations and/or dominant mutagenic events during the next round of replication (Margison and O'Conner, 1973; Bender, et al., 1974).

It has been proposed that formation of alkyl phosphotriesters through the reaction of nucleic acld phosphodlesters and alkylating agents could have serious blological effects (Ross, 1958; Freeze, 1963). In nucleic acids phosphotriesters should be less stable than phosphodiesters and should lead to hydrolysis of sugar-phosphate bonds introducing single-strand breaks Into the nucleic acid structure. Bannon and Verly (1972) have shown that in bacterla, EMS and MMS have approximately the same toxicity; however, when EMS 1s reacted with DNA $15 \%$ of the total alkylations are alkylated DNA phosphates, while with MMS only 1\% of the total alkylations occur on the phosphates. The same authors present evidence that phosphotrlesters resulting from alkylation of DNA with EMS are very stable and remain intact after heating at $100^{\circ} \mathrm{C}$ for $90 \mathrm{~min}$ at $\mathrm{pH} 7.0$. This evidence indicates that phosphotriesters formed in double-stranded DNA are stable and are probably not converted either enzymatically or chemically into single-strand breaks (Verly, 1974; Lawley, 1974a). Phosphotriesters formed in reactions with DNA probably do not contribute significantly to the mutagenic activity of EMS.

Shooter et a1., (1971) have observed that RNA bacteriophages are 
more sensitive to inactivation by monofunctional alkylating agents than are bacterlophages containing double-stranded DNA. Phosphotriesters of ribonucleotides readily hydrolyze at $\mathrm{pH} 7.0$ at $37^{\circ} \mathrm{C}$ and this may account for the increased susceptibility of RNA phages to the monofunctional agents (Shooter, et al., 1971, 1974a and 1974b). RNA phosphotr1esters can hydrolyze in one of two ways: 1) loss of the terminal part of the RNA molecule leaving a chain break or 2) slmple 108 of the alkyl group leaving the RNA chain intact (Shooter, et al., 1974b; Freeze, 1963). Thus formation of phosphotrlesters in RNA phages may not in itself be a lethal or mutagenic event. Its blological effect may well depend on the manner in which it is hydrolyzed.

Enzymatic Recognition and Repair of Alkylated DNA

Strauss and Robins (1967) found that DNA methylated in vitro by the monofunctional alkylating agent MS acts as a substrate for a speciflc nuclease activity from Micrococcus 1ysodelkticus crude extracts. This enzymatic activity produced single-strand breaks in the DNA strand which contained the methylated base and it had no effect on non-alkylated DNA. These authors suggest that perhaps two separate enzymes are active In the extracts. One enzyme recognizes and removes methylated bases while the second enzyme acts at apurinic sites to produce single-strand breaks.

Other Investigators (Kirtikar and Goldthwait, 1974; Lawley and Orr, 1970; Margison and 0'Connor, 1973; Lawley, 1973) also have provided evidence for the existence of intracellular enzymes which remove certain methylated bases and cause single-strand breaks at apurintc and posstbly apyrimidinic sites. Lawley and $\operatorname{Orr}(1970)$ reported a rapid in vivo 
removal of 3 -methyl adenine and $0^{6}$-methy1 guanine from methylated DNA. The loss of these bases occurred faster than could be accounted for by chemical hydrolysis and the authors suggested that an excision type mechanism might account for this rapid removal. Margison and $0^{\prime}$ Connor (1973) working with in vivo rat systems found that alkylated DNA In rat IIver cells lost 3-methy1 adenine much more rapidly than purifted alky1ated DNA Incubated in vitro at physiological pH. They also proposed that enzymat1c excision might account for the rapid $108 \mathrm{~s}$ of this modified base.

Kirtikar and Goldthwalt (1974) presented evidence that highly purified E. coli Endonuclease II In vitro was capable of breaking phosphodiester bonds in methylated DNA and releasing 3-methy1 adenine and $0^{6}$ methyl guanine. Verly and Rassart (1975) lsolated a highly purified E. coli endonuclease which spectfically breaks DNA at apurinic sites but does not act on methylated bases. Considering these findings Kirtikar and Goldthwalt (1974) and Verly and Rassart (1975) suggested that Endonuclease II might consist of two enzymes, one for depurination and the second for breaking phosphodiester bonds.

Endonucleases which specifically recognize apurintc sites as substrate have been isolated from bacteria, plants and mammals (Verly and Rassart, 1975; Verly et al., 1973; Lindahl and Andersson, 1972; Ljungquist and Lindahl, 1974; Verly and Paquette, 1973). These enzymes cause singlestrand breaks by hydrolyzing phosphodlester bonds near each apurinic site. Verly (1975) has shown that these enzymes are speciflc for DNA containing apurinic sites and that they do not hydrolyze intact DNA or DNA which contains only alkylated sites. Verly et al., (1974) have studied the effect of incubating labeled denatured depurinated T7 
collphage DNA for $3 \mathrm{hrs}$ at $37^{\circ} \mathrm{C}$ with an E. coli endonuclease specific for apurinfc sites, E. coli DNA polymerase I, T4 DNA ligase and a mixture of the 4 nucleoside triphosphates in Tris-Mg buffer. By the end of the incubation time both the number of apurinic sites and DNA breaks had decreased. Thus, In this in vitro system the apurinic sites were nearly a11 repafred. Omlosion of any of the three enzymes, but especially the endonuclease reduces the repair of the apurintc sites. Since an endonuclease for apurinic sites is observed in organisms of three kingdoms and can participate in an enzymatic in vitro repair of apurinic sites, these authors suggest that this endonuclease is a normal repair enzyme Involved in maintenance of DNA structure in the cell. The fact that the endonuclease hydrolyzed the phosphodiester near apurinic sites and the fact that DNA polymerase I and DNA ligase are required for In vitro repair of apurinic sites suggests that repair could occur by means of an excision repair system. Certain excision repair systems are known to be error-prone (Witkin, 1975; Grossman, 1975) and if a repair process initiated by apurinic sites is error prone then increasing apurinic sites by alkylation of bases could indirectly lead to base pair error and increase the mutation rate.

Boyd and Presley (1974) studied repair replication of DNA in first instar larvae of Drosophila melanogaster using isopycnic centrifugation technfques. Larvae were pretreated with BUdR, FUdR, penicillin and Fungazone (BUdR labels the DNA, FUdR Inhtbits the activity of thymidylate synthetase, and Fungazone enhances the uptake of BUdR). The larvae were malntained on non-nutritive media to Inhibit semi-conservative DNA replication and fed MMS or EMS in the presence of ${ }^{3} \mathrm{H}-\mathrm{BUdR}$. Both MMS and EMS stimulated repatr replication as Indicated by an un- 
scheduled non-semiconservative incorporation of ${ }^{3}$ H-BUdR Into DNA of the treated larvae. Th1s repair replication was insensitive to caffeine and hydroxyurea both of which are Inhtbitors of semi-congervative synthesis. Whether this repair replication involves an endonuclease speciflc for apurinic sites or enzymes which identify alkylated bases has not yet been determined. However, cultured cells from certain MMSsensitive mutant strains of Drosophila are also deficient for normal enzymatic UV-Induced excision repair and apparently have a reduced ability to repair endonuclease sensitive sites (Boyd, et al., 1976; Boyd and Setlow, 1976). This suggests that some enzymes may recognize both alkylated and UV-altered DNA sites as substrates. Other MMS sensitive strains have been found to be deficient for a normal postreplication repair (Boyd, et al., 1975a and 1975b).

Sega $(1974,1976)$ observed that intratesticular Injections of EMS with (250 mg/kg body welght) Induced unscheduled DNA synthesis in vartous germ cell stages in male mice. This Induced synthesis was detected by the unscheduled uptake of ${ }^{3} \mathrm{H}-\mathrm{dT}$ into DNA and occurred in cell stages ranging from early to mid-melotic prophase through early to midspermatid. EMS-induced unscheduled DNA synthesis was not observed in late spermatids. If the unscheduled DNA synthesis observed in early germ cell stages was the result of an enzymatlc repalr system, maturing spermatids, which undergo a number of physiological changes may lose the enzymes necessary for unscheduled synthesis and might not exhfbit this ability. As spermatids mature arginine-rich replace lygine-rich histones in the nucleoprotein complex and the DNA becomes tightly colled; perhaps the DNA of the late spermatid is too tightly colled to be susceptible to enzymatic action, thus preventing unscheduled DNA synthesis. 
Repalr gynthesis stimulated by treatment with alkylating agents has been reported in a number of different mammallan systems (Regan and Setlow, 1973; Roberts, et al., 1968 and 1971; Higgins et al., 1976; Ayad et al., 1969; Buhl and Regan, 1973; Scudiero, 1975). Roberts et al., (1968 and 1971) have observed that the level of repair replication in HeLa and Chinese hamster cells after treatment with MMS or EMS is directly proportlonal to the overall level of DNA alkylation. Comparing the results of experiments on $108 s$ of labeled methyl groups from alkylated DNA with those showing the absolute amount of 'repair synthests' these authors estimate that for every alkyl group 108t from DNA approximately 104 nucleotides are incorporated as a result of repair synthesis. Regan and Setlow (1973) have observed EMS-Induced repair replication in tissue cultures of human skin fibroblasts and report that only two to three nucleotides are incorporated per lesion. Scudiero et al., (1975) have also observed that only a few nucleotides per leston are incorporated by repair replication. Perhaps mamalian cells in general resemble bacterial cells which appear to have at least two types of excision repair systems (W1tkin, 1975; Grossman, 1975). One type causes exciston and replacement of long stretches of DNA while the second repairs by the replacement of much smaller regions of the DNA. Different mammalian cells could contain the information for several repalr systems but preferentially use only one for repair.

\section{A Statement of the Problem}

The mutation spectrum induced by EMS in Drosophila has several characteristics which must be considered when attempting to understand the mutation mechanism. First, the induction of mutations is stage 
speclfic with the highest frequency of Induced mutations occurring when late spermatid and spermatozoa stages are treated (Fahmy and Fahmy, 1957 and 1961; Alderson, 1965; Epler, 1966; Jenkins, 1967a and 1967b). Second, exposure of males to $25 \mathrm{mM}$ EMS Induceg a high frequency of alkylations in spermatozoa $\left(1.4 \times 10^{-2}\right.$ alky'lations per nucleotide or $1.4 \%$ of the nucleotides are alkylated), yet only $43 \%$ of the treated X-chromosomes have mutagen-induced sex-linked recessive lethal mutations (Aaron and Lee, 1978). Third, a high proportion of the mutations induced by EMS sperm treatment appear In mosalc progeny indicating that the fixation of these mutations does not occur Immediately at the time of sperm treatment but is delayed until the first or second mitotic division in the embryo (Jenkins, 1967a and 1967b; Epler, 1966; Alderson, 1967; Lee et a1., 1970). Fourth, there appears to be a time dependent Increase In the frequency of chromosome aberrations when EMS treated sperm cells are stored over a 12 day period (Abrahamson et al., 1969; Srám, 1970a and 1970b; Schalet, 1977).

Work with many organisms has provided evidence for the exlstence of cellular enzymes which can recognize and remove alkylated bases in vivo leaving apurinic or apyrimidinic sites (Strauss and Robins, 1967; Kirt1kar and Goldthwalt, 1974; Lawley and Orr, 1970; Margison and 0'Connor, 1973). Alkylated DNA bases are hydrolytically removed from treated DNA faster than are non-alkylated bases and the hydrolytic loss of bases from DNA also produces apurinic or apyrimidinic sites (Lawley and Brookes, 1963; Lindah1 and Nyberg, 1973). A second type of enzyme (an endonuclease) which recognizes these apurinic or apyrimidinic sites and converts them to single-strand breaks has been isolated from bacterla, plants, and mammals (Verly and Rassart, 1975; Verly et al., 1973; Lindah1 
and Andersson, 1972; Ljungquist and LIndalh, 1974; Verly and Paquette, 1973). Endonucleases of this type have been shown to participate In In vitro repalr of DNA carrying apurinic sites (Verly et al., 1974). Methylation and ethylation of DNA stimulates the In vivo unscheduled DNA synthesis in Drosophila larvae mitotic cells (Boyd and Presley, 1974) and male mice germinal cells (Sega, 1974 and 1976). Unscheduled DNA synthesis in mice germinal cells occurs only in stages treated prior to the late spermatid and apparently does not occur in those cell stages which are most sensitive to induction of dominant lethal mutations (Sega, 1974). In Drosophila some strains which are EMS and MS sensitive have also been found to be deficlent for spectfic enzyme activities that are required for repair functions (Boyd and Setlow, 1975; Boyd et al., 1975).

It is possible that the varfous aspects of the EMS mutation spectrum In Drosophtla described in the first paragraph of this section could result from the function or lack of function of a cellular mechanism capable of recognizing, removing and repairing ethylation damage of DNA. The stage specificity observed in Drosophila could result from the inability of a repalr system to function during certain critical stages of spermiogenesis. Those cells which are most sensitive to EMS (late spermatids and spermatozoa) are undergoing or have undergone the morphological, physiological and metabolic changes which transform spermatids into spermatozoa (Cooper, 1965; Das et a1., 1964a and 1964b; 011viert and 01iviert, 1965; Brink, 1968). These changes could result in internal environmental changes which effect the functioning of repair enzymes or the loss of the enzymes themselves. Either situation could result in an accumulation of alkylations and/or alkylation damage on the sperm DNA. The observation that a high level of DNA alkylation on sperm cell 
DNA is relatively Ineffictent in inducing sex-1inked recessive lethals (Aaron and Lee, 1978) might also result from the action of a removal mechanism which functions after fertilization in the embryo to remove and repair alkylated DNA. The enzymes, if any, involved in this embryonic system could come from sperm or ovum. The fact that a large proportion of the EMS-Induced mutations are mosaic in nature could also be accounted for by an embryonic repair system which functions during the first few mitotic divisions to remove alkylations from the embryonic DNA.

If Drogophila melanogaster has the capability of removing alkylated DNA products this removal ability should be detectable through use of appropriate radiolabeling techniques. The remainder of this dissertation describes and discusses the results of a sertes of doubleradiolabeling experiments designed to investigate the existence of such a removal system in Drosoph1la melanogaster embryos and sperm cells. 


\section{METHODS AND MATERIALS}

The sex chromosome complement of the normal Drosophila male and female genomes consists of a free $X$ - and a free $Y$-chromosome, and two free X-chromosomes, respectively. Normally the X-chromosome consists of a long left arm (XI), a centromere and a minute right arm (XR). The normal Y-chromosome consists of a long arm (YL), a centromere and a short arm $\left(Y^{S}\right)$ and carries two sets of factors necessary for male fertility. The first set of male fertility factors (KL) is on the $\mathrm{Y}^{\mathrm{L}}$ and consists of flve clstrons (k11-k15), while the second set (KS) is on the YS and conslats of two fertility genes (ks1 and $\mathrm{ks} 2$ ). Loss of the entire $Y$ or either of the $Y$ arms or even any one of the male fertility genes results in male sterility. However, rearrangement of the Ychromosome without 1088 of any part of it does not effect the fertility of males. The $X$ - and Y-chromosomes each carry a normal allele for the production of ribosomal RNA. This locus located near the centromere of either chromosome is designated the bobbed locus (bb). Genomes that are deficient for the bobbed locus are genetically Imbalanced and inviable (LIndsley and Grell, 1972).

Mating Scheme for the Males

The mating scheme for the production of the males used in these experiments is 1llustrated in Figure 1. Males of one stock (C) which carry a genetic rearrangement of sex-chromosomes are crossed to females of a second stock (D) that carry a different rearrangement of the sexchromosomes. In stock $\underline{\mathrm{C}}$ males the short arm of the Y-chromosome $1 \mathrm{~s}$ 


\begin{tabular}{|c|c|c|}
\hline$C$ males & & D females \\
\hline $\mathrm{Y}) \mathrm{L}, \mathrm{bb}^{-} / \mathrm{X} \cdot \mathrm{Y}^{\mathrm{S}}, \operatorname{In}(\mathrm{I}) \mathrm{EN} 2, \underline{\mathrm{fb}}{ }^{+}$ & & \\
\hline
\end{tabular}

Female gametes

\begin{tabular}{|c|c|c|}
\hline Male gametes & $\mathrm{Y}^{\mathrm{L}} \cdot \mathrm{sc}^{\mathrm{sl}}, \mathrm{y}^{+} \mathrm{ac}^{+} \mathrm{bb}^{+}$ & $C(I) D X, y \in \mathrm{bb}^{-}$ \\
\hline$\underline{\mathrm{R}(\mathrm{Y}) \mathrm{L}}, \underline{\mathrm{bb}}^{-}$ & 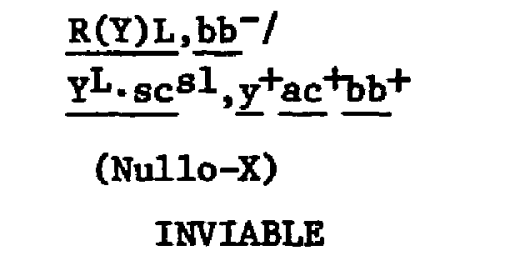 & $\begin{array}{l}\frac{\mathrm{R}(\mathrm{Y}) \mathrm{L}}{\mathrm{C}}, \underline{\mathrm{bb}}-\mathrm{l} \\
\frac{\mathrm{C}(\mathrm{I}) \mathrm{DX}}{\mathrm{y}}, \underline{\mathrm{f}} \underline{\mathrm{bb}}- \\
\begin{array}{c}\text { (bobbed deficient) } \\
\text { INVIABLE }\end{array}\end{array}$ \\
\hline , In(I) $\mathrm{EN}^{2}, \underline{\mathrm{f}} \underline{\mathrm{bb}}^{+}$ & 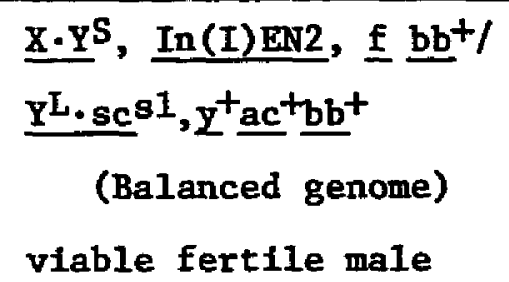 & 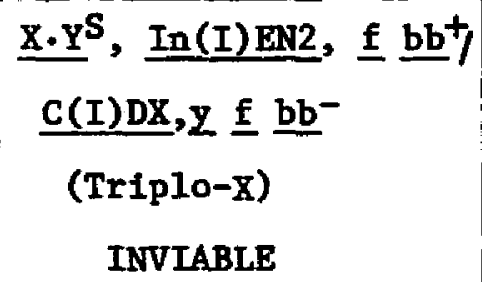 \\
\hline
\end{tabular}

Figure 1. Mating scheme for the production of only fertile CD male embryos. 
attached to the $X$-chromosome $\left(X \cdot Y^{S}\right)$ and the two ends of the long arm of the Y-chromosome are Joined to form a clrcular Y-chromosome, the $R(Y) L$. The $R(Y)$ I chromosome is deficlent for the bobbed locus (bb ${ }^{-}$). The two X-chromosomes in the stock $\underline{D}$ females are folned at the centromeric ends to form a single tandem reversed acrocentric X-chromosome, (C(1)DX) which is defictent for the bobbed locus (bb-). To balance this defictency the stock $\underline{D}$ genome contains a free $\mathrm{Y}^{\mathrm{L}} \cdot \mathrm{sc}^{81}$ chromosome that carrles a bobbed locus ( bb $^{+}$) and consists of a $\mathrm{Y}^{\mathrm{L}}$ attached to a small plece of the X-chromosome.

Four embryonic genotypes are possible when stock $\underline{\mathrm{C}}$ males are mated to stock $\underline{D}$ females (Figure 1). Because of the metotic segregation of the rearranged sex-chromosomes in the parental flies only male embryos are genetically balanced and capable of producing viable fertile progeny. Two of the embryonic genotypes are inviable because they contain sex-chromosome imbalances (triplo-X and nullo-X embryos), while a third genotype is inviable because it is bobbed deficlent ( $\left.\underline{b}^{-}\right)$.

Mating Scheme for the Females

The virgin females used in these experiments were produced according to the scheme 1llustrated in Figure 2. Stock $\underline{F}$ males which have a normal $\mathrm{Y}$-chromosome and a complete but rearranged $\mathrm{X}$-chromosome are mated to stock $\underline{0}$ females which have two complete but rearranged $X-$ chromosomes each of which carries one sex-linked recesgive lethal mutation (Lee, et al., 1972). The recessive lethals (1(1) J1 and 1) carried on the two $\mathrm{X}$-chromosomes of the female are non-allelic and do not effect the viability of the stock $\underline{0}$ female.

Four embryonic genotypes are produced as a result of this cross 


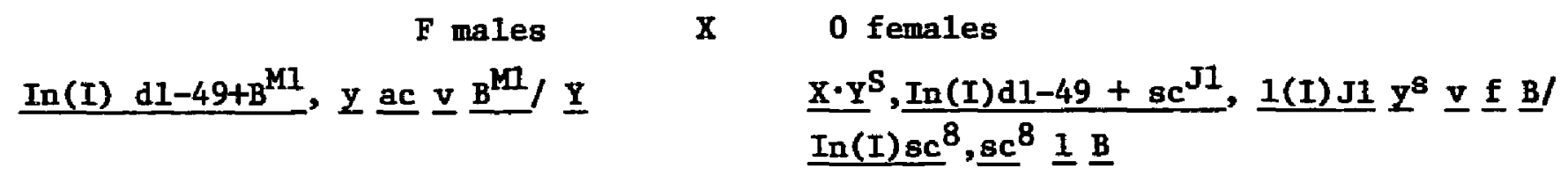

Female gametes

\begin{tabular}{|c|c|c|}
\hline Male gametes & 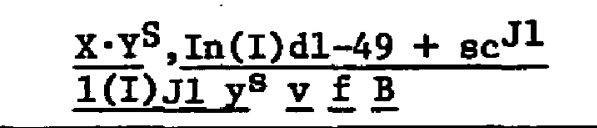 & $\underline{\operatorname{In}(I) s c^{8}}, s c^{8} \underline{1} \underline{B}$ \\
\hline $\mathbf{Y}$ & 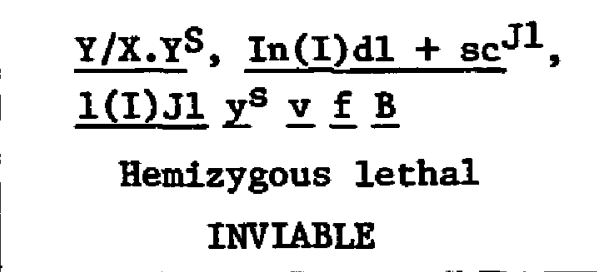 & $\begin{array}{l}\underline{Y / \operatorname{In}(I) s c^{8}}, \underline{s c}^{8} \underline{1} \underline{B} \\
\text { Hemizygous lethal } \\
\text { INVIABLE }\end{array}$ \\
\hline$\frac{\operatorname{In}(I) \mathrm{d} 1-49+\mathrm{B}^{\mathrm{M} 1}}{\mathrm{I} \text { ac } \mathrm{v} \underline{B}^{\mathrm{Ml}}}$ & 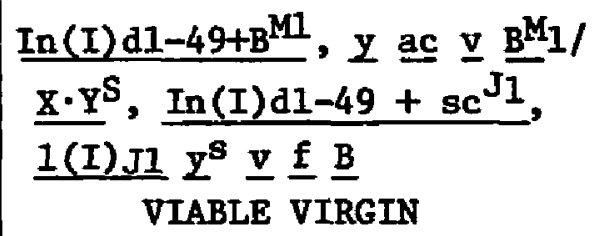 & $\begin{array}{l}\frac{\operatorname{In}(\mathrm{I}) \mathrm{d} 1-49+\mathrm{B}^{\mathrm{Ml}}}{\operatorname{In}(\mathrm{I}) \mathrm{sc}^{8}, \mathrm{sc}^{8}}, \underline{\mathrm{I}} \underline{\mathrm{B}} \\
\text { VIABLE VIRGIN }\end{array}$ \\
\hline
\end{tabular}

Figure 2. Mating scheme for the production of $\underline{Q}$ virgins. 


$\frac{\text { Sterilizer male }}{\underline{\mathrm{R}(\mathrm{Y}) \mathrm{L} / \underline{\mathrm{X}}^{\mathrm{Y}} \mathrm{S}}} \quad \mathrm{X} \quad \frac{\text { Oregon-R virgin }}{\underline{\mathrm{X} / \mathrm{X}}}$

Female gametes

$\underline{\mathbf{X}}$

\begin{tabular}{l|c|} 
Male gametes \\
$\underline{\mathrm{R}(\mathrm{Y}) \mathrm{L}}$ & $\begin{array}{c}\underline{\mathrm{R}(\mathrm{Y}) \mathrm{L} / \underline{\mathrm{X}}} \\
\text { (Deficient for } \mathrm{Y}^{\mathrm{S}} \text { ) } \\
\text { STERILE MALE }\end{array}$ \\
\hline$\underline{\mathrm{X} . \mathrm{Y}^{S}}$ & $\underline{\mathrm{X} . \mathrm{Y}^{\mathrm{S}} / \underline{\mathrm{X}}}$ \\
& FERTILE FEMALE \\
\hline
\end{tabular}

Figure 3. Mating scheme for the production of wild-type automatic virgins. 
(Figure 2). The two male embryonic genotypes $(\mathrm{X} / \mathrm{Y})$ each receive a lethal bearing $\mathrm{X}$-chromosome from the maternal genome and since they are hemizygous for the $\mathrm{X}$-1inked recessive lethal these embryos are inviable. The other two embryonic genotypes $(X / X)$ are viable since the lethal on the maternal $X$ is balanced with a normal allele carried on the paternal X. The viable embryos produce females and since there are no males these females are all virgin. The females produced by thls cross are given the designation $Q$ virgins. Both genotypes were used in the following experiments.

Wild type automatic-virgin females are produced in large numbers by crossing small numbers of normal Oregon-R (wild type) females to sterilizer $\left(\underline{R(Y) L / X \cdot Y^{S}}\right)$ wild type males. As 11lustrated In Figure 3 all male progeny resulting from crosses of oregon-R virging to $R(Y) L / X \cdot Y S$ males are sterile because they lack the $\mathrm{Y}^{S}$ portion of the $\mathrm{Y}$-chromosome and Its associated fert1lity factors. Therefore, the females produced from this cross are automatically virgin.

32p Labeling

Stock $\underline{D}$ females that had been Inseminated by stock $\underline{C}$ males were placed on 32P-labeled media in 1-pint glass milk bottles and were allowed to deposit eggs over a four-hour period. Each glass bottle contained $50 \mathrm{ml}$ of a corn-meal agar media plus approximately $300 \mu \mathrm{CI}$ of $32 \mathrm{P}$. The 32P was incorporated into the media in the form of carrierfree $\mathrm{H}_{3}{ }^{32} \mathrm{PO}_{4}$ (New England Nuclear) and the final ${ }^{32} \mathrm{P}$ concentration of the media was approximately $6 \mu \mathrm{Ci} / \mathrm{ml}$. of media.

The $C D$ larvae which hatched from these eggs were maintained on the 32p-labeled media until they became third instars, at which time 
the larvae were floated off the $32 \mathrm{P}$-media with a $30 \%$ sucrose solution and washed with room temperature water to remove any ${ }^{32} \mathrm{p}$ media which might have been carried over during the floating procedure. The washed larvae were placed on non-radloactlve media and allowed to develope without further disturbance Into adult male flies. In this way the DNA of the CD males is randomly labeled with ${ }^{32} \mathrm{P}$ so the radiolsotope can be used as a marker nuclide to detect sperm-derived DNA in sperm and embryo DNA extracts.

The number of ${ }^{32} \mathrm{P}$ atoms per sperm DNA = the number of ${ }^{32} \mathrm{P} \mathrm{dpm}$ per sperm cell/the decay constant for ${ }^{32} \mathrm{P}$. The number of dpm per sperm cell estimated for each embryo sample $=\mathrm{dpm}{ }^{32} \mathrm{P}$ in the DNA extract of the sample/the number of embryos per sample corrected for fertility (Appendix I and Table VIII). Since polyspermy is a rare event in Drosoph1la melanogaster (Hildreth and Lucches1, 1963) the denominator estimates the number of labeled sperm cells which contributed $32 \mathrm{P}$ to the sample. The mean number of ${ }^{32} \mathrm{P}$ atoms per sperm cell DNA estimated using the samples from all experiments (Appendix 11 and Table 1) is 1413. Since there are approximately $3 \times 10^{8}$ nucleotides per Drosophila sperm DNA (Laird, 1973) this level of ${ }^{32} \mathrm{P}$ labeling is equivalent to $4.7 \times 10^{-6} 32 \mathrm{P}$ atoms per nucleotide.

\section{$\underline{3 \mathrm{H}-\mathrm{EMS}}$ Treatment of $\underline{\mathrm{CD}}$ Males}

Four-day old adult ${ }^{32} \mathrm{P}-1$ abeled $\mathrm{CD}$ males were treated with a tritiated form of the alkylating agent ethyl methanesulfonate ( $3 \mathrm{H}-\mathrm{EMS})$. The ${ }^{32} \mathrm{P}-1$ labeled males were exposed to the $3 \mathrm{H}-\mathrm{EMS}$ by one of two methods: 1) a sucrose feeding method or 2) a vapor treatment method. Two forms of the ${ }^{3} \mathrm{H}$-EMS were used in this series of experiments. Ethyl-2-3 $\mathrm{H}-$ methanesulfonate ([1-3 H]EMS) was obtained from New England Nuclear 
(Lot \#599-183) at a specific activity of $355 \mathrm{mCl} / \mathrm{mM}$ and was used in two of the feeding experiments. Ethy1-1-3 $\mathrm{H}$-methanesulfonate ([1-3 $\mathrm{H}]$ EMS) was obtained from New England Nuclear (Lot \#816-209) at a specific activity of $6100 \mathrm{mCl} / \mathrm{mM}$ and was used in one feeding experiment and in the three vapor treatment experiments. Radiochemical purity was verified by showing that the labeled compound co-chromatographed with unlabeled EMS In the gas chromatograph (Aaron and Lee, 1978). The tritium label in the ${ }^{3} \mathrm{H}$-EMS was verified as being only on the ethyl group by showlng that the only labeled hydrolysis product co-chromatographed with ethanol In the gas chromatograph (Aaron and Lee, 1978). The tritium labeled ethyl group could then be detected in DNA extracts from sperm and embryos.

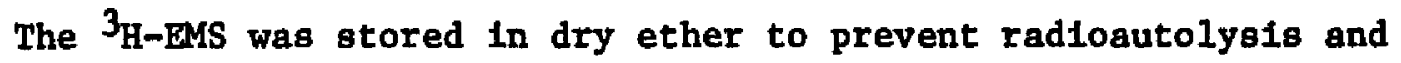
prepared for feeding by the method of Aaron and Lee (1978). A modification of the feeding method of Lewis and Bacher (1968) using glass filter supports (Aaron et al., 1977) was used to expose 32P-1abeled CD

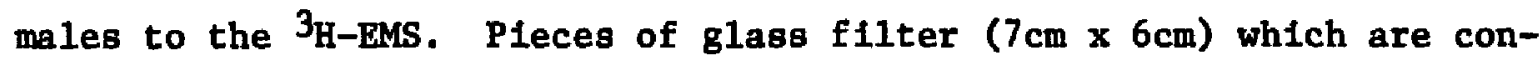
tained in glass vials $(9 \mathrm{~cm} \times 2.5 \mathrm{~cm})$ are impregnated with ${ }^{3} \mathrm{H}-\mathrm{EMS}$ dissolved In a $1 \%$ sucrose solution. Fifty 32 p-labeled males are placed in each feeding vial and allowed to imbibe the $3_{\mathrm{H}-\text { EMS }}$ solution for 24 hours. Three feeding experiments were conducted. In two of the exper1ments the males were exposed to $12.2 \mathrm{mM}\left[2{ }^{3} \mathrm{H}\right]$ EMS (specific activity, $355 \mathrm{mCl} / \mathrm{mM}$ ) per vial. In the third experiment the males were exposed to $0.38 \mathrm{mM}\left[1-^{3} \mathrm{H}\right]$ EMS (specific activity, $6100 \mathrm{mCl} / \mathrm{mM}$ ) per vial. Using the log-exposure-log-dose relationship given in Aaron and Lee (1978) an EMS exposure level of $0.38 \mathrm{mM}$ is equivalent to a dose of $7.5 \times 10^{-4}$ ethylations per nucleotide on the DNA. 
The apparatus and method described by Aaron et al. (1977) (Append1x III) was used to expose large numbers of 32p-labeled CD males (500-1000) to [1-3 H] EMS vapor. 32p-labeled males were placed in a $250 \mathrm{~m} 1$ vaccuum

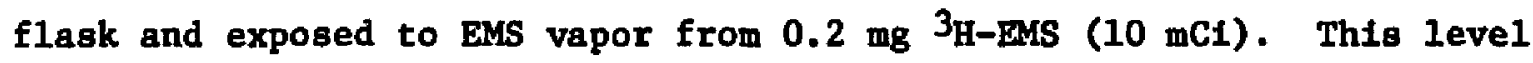
of exposure gives a $6.0 \%$ mutation frequency in genetic tests for sexlinked recessive lethals (Aaron et al_., 1977). Using the sex-linked recessive lethal frequency as a 'secondary dosimeter' the mutation frequency can be converted to dose in terms of alkylation par nucleot1de. The dose-response curve of Aaron and Lee (1978) Indicates that a $6.0 \%$ sex-1inked recessive lethal frequency is equivalent to a dose of $6.7 \times 10^{5}$ ethylations per sperm cell. Considering that there are approximately $3 \times 10^{8}$ nucleotides per sperm cell (Laird, 1973) this dose is equivalent to $2.2 \times 10^{-3}$ ethylations per nucleotide.

\section{Sperm and Egg Sampling}

The $3_{\text {H-EMS }}$ treated males were placed on non-radioactive media and allowed a 24 hour recovery perlod. Following the recovery perlod the treated males were mated to virgin females in a ratio of one male to five females. After the three day mating perfod the inseminated females are separated from the treated males and are used for the collection of sperm and egg samples.

An Insemfnated female stores the sperm transferred from the male In her seminal receptacle. Samples of sperm cells are obtained by removing the receptacles from a random sample of the inseminated females. The receptacles are dissected from the females into 0.1 standard saline citrate (SSC) and Immediately frozen over dry ice on a small $(0.5 \mathrm{~cm} \times 0.5 \mathrm{~cm})$ piece of glass filter. The dissected receptacles are 
stored in the cold $\left(-25^{\circ} \mathrm{C}\right)$ until DNA extraction.

Egg samples are collected using specially designed egg collecting chambers. The egg collecting chambers conslst of elght-ounce plastlc disposable beer glasses, squares of black sheath cloth $(6.5 \mathrm{~cm} \times 6.5 \mathrm{~cm})$ and three $\mathrm{cm}$ pleces of plastic tublng ( $1.3 \mathrm{~cm} 0 . \mathrm{D} . ; 1.0 \mathrm{~cm} \mathrm{I.D).} \mathrm{The}$ plastic glasses are modifled by cutting off the tip end of the neck and the upper four $\mathrm{cm}$ of the vessel. A plece of black sheath cloth is stretched over the mouth of the modified plastic glass and secured in place with a small rubber band. The Inseminated females are divided Into groups of 250 to 500 flies and each group is placed in a separate collecting chamber. Two Identical collecting chambers are used for each group. One chamber is used to hold the flies when they are not being used for egg collection, while the second chamber is used when the flies are forced to deposit eggs. The plastic tubing is used to connect the open neck end of the holding chamber with the open neck end on the collecting chamber. The females are then shaken into the collecting chamber and subjected to an anesthetizing dose of carbon dioxide gas. Under these conditions an egg held in the uterus is released from the vagina. As an egg passes through the uterus it is penetrated by a sperm cell and thus released from the vagina as a newly fertilized egg (Miller, 1965). Once the females have deposited the eggs they are staken back to the holding chamber and maintained on media with yeast supplement. The time lapse between anesthetizing the females and removal of the females 1s approximately five minutes. Therefore, when the females are removed from the collecting chamber, the eggs deposited on the cloth will range In age from 0 to 5 minutes. 
The female flies deposit the eggs on the black sheath cloth and the walls of the collecting chamber. The black sheath cloth 1s carefully removed from the chamber and spread over a glass funnel. The eggs along the chamber wall are then washed onto the cloth with room temperature water. The number of eggs in each sample are counted under a disgectIng microscope and then the eggs are allowed to develop at $25^{\circ} \mathrm{C}$ to the desired embryontc stage. When the embryos in a sample reach the proper embryonic stage as determined by the timed schedule of Rabinowitz (194I), development is stopped by transferring the embryog to a square plece $(4.0 \mathrm{~cm} \times 4.0 \mathrm{~cm})$ of polyethylene and freezing them in $0.1 \mathrm{x}$ sSC on a block of dry 1ce. Prior to freezing, embryos from each embryonic stage sampled were selected at random and cytologically prepared to verify the embryonic stage and determine the percent of embryos retained from stage to stage. The remaining embryos were stored at $-25^{\circ} \mathrm{C}$ until DNA extraction. During the DNA extraction embryo samples stopped at the same stage of development were pooled to form larger samples of 1000 to 3000 embryos.

The cytological samples were prepared in the following inanner. Eggs were dechorionated by placing them in a 1\% Chlorox solution and gently brushing the chorion with a small (number 000) brush. The dechorionated eggs were placed on microscope slides (4 eggs/slide) and squashed in the presence of aceto-orceln stain (Oster and Balaban, 1963) under a thin (No. 0) cover glass. The cover glass was sealed to the slide with a clear finger nall polish. The preparations were allowed to stain at least a week before they were cytologically examined.

\section{DNA Extraction Procedure}

High molecular weight DNA was extracted from the sperm and embryo 
aamples by the enzymatic-phenolic extraction procedure described by Aaron and Lee (1978). By measuring the removal of ${ }^{14} \mathrm{C}$-arginine this extraction procedure has been shown to remove more than $99 \%$ of the proteln associated with the DNA (Aaron and Lee, 1978). Blank samples of DAA from non-1abeled embryos and sperm were extracted to provide a means to accurately determine the background counts for the DNA cockta11s. The purity of the extracted resuspended DNA dissolved in $0.1 \times$ SSC was determined by measuring its UV-absorbance spectra using a Beckman Model DB-GT spectrophotometer. The absorbance of the $1 \mathrm{ml}$ DNA solutions was measured versus a blank of $0.1 \times$ SSC at wave lengths between 240 and $300 \mathrm{~nm}$.

The amounts of $3_{\mathrm{H}}$ and $32 \mathrm{p}$ in each DNA sample was determined by liquid scintillation counting in a Packard Tri-Carb model 3320. The Instrument has three counting channels (channels $A, B, C$ ) and was calibrated to give maximum ${ }^{3} \mathrm{H}$ efficlency in the $A$ channel and maximum ${ }^{32} \mathrm{P}$ efficiency in the C channel. The DNA extract of each sample was transferred to a counting vial. Ten ml of Instagel counting cocktall (Packard) Is added to each DNA sample and the contents of the vial were shaken to Insure uniform dispersion of the extract. The cocktalls were placed in the refrigerated scintillation counter and allowed to cool and stabilize for at least 24 hours. The radiolabeled DNA samples and corresponding DNA blank samples were counted in 100 minute increments unt11 10,000 counts were accumulated in both the tritium and phosphorus channels.

Counts per minute (cpm) were converted to disintegrations per minute (dpm) by correcting for background counts, spillover between 
channels, machine counting efficlency, and tsotopic decay using a computerized data analysis system (Aaron and Lee; 1975). Splllover between channels, and counting efficiency were determined by the internal standardization method. The phosphorus counts were standardized for decay and spillover by adding allquots $\left(3.0 \times 10^{-5} \mathrm{mCl}\right)$ of the labeled phosphorlc actd solution orfginally used to make the labeled media. Since the radioactive phosphorus in the sampled DNA and the original phosphoric actd solution have decayed to the same extent, this phosphoric acid Internal standard has the same proportion of ${ }^{33} \mathrm{P}$ to ${ }^{32} \mathrm{P}$ for decay and spillover correction as the DNA sample. The phosphorus counts were standardized for efficiency by adding aliquots $\left(3.0 \times 10^{-5} \mathrm{mCl}\right)$ of a ${ }^{32} \mathrm{P}$ certified standard (New England Nuclear).

The tritium counts were standardized by adding aliquots (approximately $3.0 \times 10^{-5} \mathrm{mCl}$ ) of a ${ }^{3} \mathrm{H}$-hexadecane certified standard solution (Amersham-Searle).

The determination of true cpms in a counting channel due to a particular isotope required an adjustment for apillover between channels; 1.e., counting shifts from one isotope into a channel counting another isotope. The spillovers are computed using the equations:

1) Spill over $\mathrm{A} \rightarrow \mathrm{C}=\alpha^{3} \mathrm{H}=\frac{3_{\mathrm{H}} \text { counts in Channel } \mathrm{C}}{3_{\mathrm{H}} \text { counts in Channel } \mathrm{A}}$

2) Spill over $\mathrm{C} \longrightarrow \mathrm{A}=\alpha^{32} \mathrm{P}=\frac{32_{\mathrm{P}} \text { counts in Channel } \mathrm{A}}{32_{\mathrm{P}} \text { counts in Channel } \mathrm{C}}$ The correction in each channel for sp111 over is made using the equations : 
3) True $3_{\mathrm{H}}$ counts $\left.=\left(\mathrm{N}_{3_{\mathrm{H}}}-\mathrm{B}_{3_{\mathrm{H}}}\right)-\alpha^{32 \mathrm{P}\left(\mathrm{N}_{32} \mathrm{P}\right.}-\mathrm{B}_{32}\right) / 1-\alpha^{32} \mathrm{P} \alpha^{3} \mathrm{H}$

4) True ${ }^{32} \mathrm{P}$ counts $=\left(\mathrm{N}_{32}-\mathrm{B}_{32}\right)-\alpha^{3} \mathrm{H}\left(\mathrm{N}_{3_{H}}-\mathrm{B}_{3_{H}}\right) / 1-\alpha^{32} \mathrm{P} \alpha^{3_{H}}$

Where; $N=$ counts per minute and $B=$ background counts per minute.

The true cpm due to a particular lsotope are converted to dpm using the equation:

5) dpm $=\frac{\text { cpm }}{\text { (counting efficiency) (1sotope decay coefficient) }}$

The half-life for ${ }^{3} \mathrm{H}$ is 12.26 years. Since the decay coefficient for $3_{\mathrm{H}}$ is 0.00015 day $^{-1}$ during the courge of an experiment ( 3 months) the $3_{\mathrm{H}}$ decay was mintmal and for correction purposes was zero. ${ }^{32} \mathrm{P}$ has a half-life of 14.22 days and a decay coefficient of 0.04873 day $^{-1}$. Therefore a decay correction must be made when computing $32 \mathrm{P} \mathrm{dpm}$ because a constderable amount of ${ }^{32} P$ is lost during the course of an experiment. The ${ }^{3} \mathrm{H}$ and ${ }^{32} \mathrm{P}$ counts in each sample were corrected for

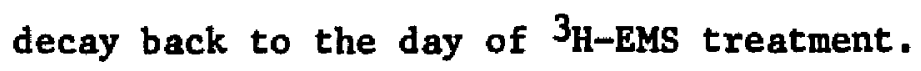

The analysis of the counts on a serles of certified sealed standards (Packard Instruments) provided an independent determination for the consistency of the efficlency of counting and spillover ratios for the liquid scintillation counter. These sealed standards were counted along with the DNA samples from the Initial counting of the samples to the completion of the internal standardizations. The sealed standard series consisted of a sealed blank; unquenched samples of ${ }^{3} \mathrm{H},{ }^{14} \mathrm{C}$ and ${ }^{36} \mathrm{Cl}$; and quenched samples of ${ }^{14} \mathrm{C}$. Thus, the consistency of performance for the liquid scintillation counter could be checked over a wide range of energy levels. 
Stat1stical Analysio Based on Experimental Varlance

A two-way analysis of variance using the F-test was performed on the ${ }^{3} H /{ }^{32} P$ ratios derlved from the DNA extractions. The ratios are compared using a randomized block design to test the null hypothesis that there is no significant difference in vartance due to treatment effects. The treatments in each comparison consist of the sperm cells and one or several or the embryo stages. Experimental variance was determined as variation among the ${ }^{3} \mathrm{H} /{ }^{32} \mathrm{P}$ samples within replicates.

A t-test was used to analyze observed rates of reduction of $3 \mathrm{H}-$ ethyl groups in the DNA extracts to determine if these rates were the same as the rate of spontaneous hydrolytic depurination of alkylated DNA.

Calculation of Standard Deviations for the ${ }^{3} \mathrm{H} /{ }^{32} \mathrm{P}$ Ratios based on Sampling Error

The standard deviations based on sampling error for the ${ }^{3} \mathrm{H} / \mathbf{3 2}_{\mathrm{P}}$ rat1os were computed In a stepwise manner. First, standard deviations based on total counting time and total counts uncorrected for decay were determined for the $3_{\mathrm{H}}$ and $32 \mathrm{P}$ counts separately. The standard deviations for the ${ }^{3} \mathrm{H}$ and ${ }^{32} \mathrm{P}$ counts were computed using the formula:

Standard Deviation $=\frac{\sqrt{n_{s} t_{b}^{2}+n_{b} t_{s}^{2}}}{t_{b} t_{s}}$

where; $n_{s}=$ The total counts on the sample

$n_{b}=$ The total counts on the corresponding blank

$t_{B}=$ The total time the sample was counted

$t_{b}=$ The total time the corresponding blank was counted. 
This formula was derived from the otandard formula for determining the standard deviation based on sample counting rates:

Standard Deviation $\sqrt{\frac{r_{s}}{t_{s}}+\frac{r_{b}}{t_{b}}}$

where; $\mathbf{r}_{\mathbf{g}}=$ The counting rate of the sample

$r_{b}=$ The counting rate of the corresponding blank

$t_{B}=$ The counting time of the sample

$t_{b}=$ The counting time of the corresponding blank.

Since: $\quad r_{8}=\frac{\text { Gross counts of sample }}{t_{8}}=\frac{n_{8}}{t_{s}}$

and: $\quad r_{b}=\frac{\text { Gross counts of blank }}{t_{b}}-\frac{n_{b}}{t_{b}}$

when substitution for $r_{g}$ and $r_{b}$ is made, equation (2) can be rearranged to yield equation (1).

In the second step the relative standard deviations for the ${ }^{3} \mathrm{H}$ and ${ }^{32} \mathrm{P}$ total counts uncorrected for decay were computed by dividing the standard deviation based on counting time for a particular 1sotope by the counting rate for the isotope. The relative standard deviations for the ${ }^{3 \mathrm{H} /{ }^{32} \mathrm{P}}$ ratio was computed by adding the relative standard deviations for the ${ }^{3 \mathrm{H}}$ and $32_{\mathrm{P}}$ counts. The standard deviation for the ${ }^{3 \mathrm{H} /}{ }^{32} \mathrm{P}$ ratio is determined by multiplying the relative standard deviation for the ratio by the value of the ratio. 
RESULTS

Stabllity of Alkyl Groups in the Embryo

SIx experiments were conducted to determine the stability of ethyl groups In the Drosophila embryo. Embryo samples were collected from either wild-type automatic virgins or $Q$ virgins that had been inseminated by the ${ }^{3} \mathrm{H}$-EMS treated ${ }^{32} \mathrm{P}$-labeled $\mathrm{CD}$ males. Embryos were sampled at the following stages: 1) premitotic (15 minutes after deposition); 2) first mitotic division (20 and 25 minutes after deposition); 3) second mitotic division (30 minutes after deposition) and 4) gastrulation following cellularity of the embryonic syncytium (180 minutes after deposition) (Rabinowitz, 1941). In each experiment the males are mated for three days sequentially to two groups of females and the samples from these matings are designated Mating 1 for group 1 females and Mating 2 for group 2 females. The ${ }^{3} \mathrm{H} /{ }^{32} \mathrm{P}$ ratios derived from each mating is labeled accordingly (Table 1 ).

Among the first five experiments, sperm samples and the 180 minute embryo (gastrula) samples are common to all experiments. Table II shows the F-test analyols of varlance for the $3_{\mathrm{H} /}{ }^{32} \mathrm{P}$ ratios derived from the sperm and 180-minute embryo samples. The analysis was done in a randomized block design where treatments were the sperm and the 180 minute embryos, and each experiment was considered as a separate block. Therefore, there were two treatments, flve blocks, and 19 degrees of freedom for the analysis. The ANOVA Indicates that there was a significant difference $(P<0.025)$ between the Isotopic ratios from the sperm cells and 
TABLE I. THE ${ }^{3}$ H/ ${ }^{32}$ P RATIOS FROM SPEEM AND EMBRYO SAMPLES FROM SIX DIFFEREMT EXPERTMEMTS

\begin{tabular}{|c|c|c|c|c|c|c|c|c|c|}
\hline & $\begin{array}{l}\text { Sperm } \\
\text { Ce118 }\end{array}$ & $\begin{array}{l}\text { Embryos } \\
\text { (15 min) }\end{array}$ & $\begin{array}{l}\text { Bmbryos } \\
(20 \mathrm{~min})\end{array}$ & $\frac{\text { Babryos }}{(25 \text { min) }}$ & $\begin{array}{l}\text { Bubryos } \\
(30 \mathrm{~min})\end{array}$ & $\begin{array}{c}\text { Embryos } \\
(180 \mathrm{~min})\end{array}$ & $\begin{array}{c}\text { Bmbryos } \\
(3-12 \text { hrs })\end{array}$ & $\mathrm{P}_{1}{ }^{\mathrm{g}}$ & $\mathbf{p}_{2}{ }^{\mathbf{h}}$ \\
\hline \multicolumn{10}{|c|}{ Expertment $1^{b, e}$} \\
\hline Mating 1 & $\begin{array}{l}0.51^{a} \\
( \pm .01)\end{array}$ & - & - & - & - & $\begin{array}{c}0.22 \\
\pm .003)\end{array}$ & - & & \\
\hline Mating 2 & $\begin{array}{l}0.62 \\
( \pm .02)\end{array}$ & - & - & - & - & $\begin{array}{c}0.10 \\
( \pm .003)\end{array}$ & - & 0.17 & - \\
\hline \multicolumn{10}{|c|}{ Experiment $2^{b, e}$} \\
\hline Mating 1 & $\begin{array}{l}1.15 \\
( \pm .07)\end{array}$ & - & - & - & - & $\begin{array}{c}0.10 \\
( \pm .003)\end{array}$ & $\begin{array}{c}0.08 \\
( \pm .003)\end{array}$ & & \\
\hline Mating 2 & $\begin{array}{l}0.39 \\
( \pm .06)\end{array}$ & - & - & - & - & $\begin{array}{c}0.10 \\
( \pm .003)\end{array}$ & $\begin{array}{c}0.09 \\
( \pm .003)\end{array}$ & 0.13 & 0.97 \\
\hline \multicolumn{10}{|c|}{ Experiment $3^{c, f}$} \\
\hline $\begin{array}{l}\text { Feeding } 1 \\
\text { Mating } 1\end{array}$ & $\begin{array}{l}1.39 \\
( \pm .32)\end{array}$ & - & $\begin{array}{l}0.11 \\
( \pm .02)\end{array}$ & - & - & $\begin{array}{r}0.18 \\
( \pm .02)\end{array}$ & $\begin{array}{c}0.13 \\
( \pm .01)\end{array}$ & & - \\
\hline $\begin{array}{l}\text { Feeding } 2 \\
\text { Mating } 1\end{array}$ & $\begin{array}{l}1.27 \\
( \pm .17)\end{array}$ & - & $\begin{array}{l}0.16 \\
( \pm .006)\end{array}$ & - & - & $\begin{array}{r}0.17 \\
( \pm .01)\end{array}$ & $\begin{array}{c}0.22 \\
( \pm .02)\end{array}$ & $<0,01$ & 0.53 \\
\hline
\end{tabular}


TABLE I (Continued)

\begin{tabular}{|c|c|c|c|c|c|c|c|c|c|}
\hline & $\begin{array}{l}\text { Sperm } \\
\text { Ce11s }\end{array}$ & $\begin{array}{l}\text { Embryos } \\
(15 \text { min) }\end{array}$ & $\begin{array}{l}\text { Embryos } \\
(20 \mathrm{~min})\end{array}$ & $\begin{array}{l}\text { Embryos } \\
\text { (25 min) }\end{array}$ & $\begin{array}{l}\text { Embryos } \\
(30 \mathrm{~min})\end{array}$ & $\begin{array}{l}\text { Embryos } \\
\text { (180 min) }\end{array}$ & $\begin{array}{l}\text { Embryos } \\
\text { (3-12 hrs) }\end{array}$ & $P_{1}{ }^{8}$ & $\mathbf{P}_{2}{ }^{\mathbf{h}}$ \\
\hline \multicolumn{10}{|c|}{ Experiment $4^{\mathrm{d}, \mathrm{f}}$} \\
\hline Mating 1 & $\begin{array}{l}5.57 \\
( \pm .43)\end{array}$ & $\begin{array}{c}1.94 \\
( \pm .09)\end{array}$ & -- & $\begin{array}{c}1.85 \\
( \pm .08)\end{array}$ & - & $\begin{array}{c}1.13 \\
( \pm .04)\end{array}$ & --- & & \\
\hline Mating 2 & $\begin{array}{l}2.12 \\
( \pm .08)\end{array}$ & $\begin{array}{c}0.23 \\
( \pm .004)\end{array}$ & -- & $\begin{array}{c}0.18 \\
( \pm .008)\end{array}$ & - & $\begin{array}{c}0.18 \\
(+.009)\end{array}$ & -- & 0.018 & 0.59 \\
\hline \multicolumn{10}{|c|}{ Experiment $5^{\mathrm{d}}, \mathrm{f}$} \\
\hline Mating 1 & $\begin{array}{l}0.32 \\
( \pm .09)\end{array}$ & $\begin{array}{c}0.10 \\
( \pm .01)\end{array}$ & -- & $\begin{array}{c}0.11 \\
(\stackrel{+}{*} 01)\end{array}$ & - & $\begin{array}{c}0.08 \\
( \pm .01)\end{array}$ & -- & & \\
\hline Mating 2 & $\begin{array}{l}0.30 \\
( \pm .03)\end{array}$ & -- & - & $\begin{array}{c}0.03 \\
( \pm .01)\end{array}$ & - & $\begin{array}{c}0.04 \\
(\stackrel{+01)}{-})\end{array}$ & $\cdots$ & $<0.01$ & 0.67 \\
\hline \multicolumn{10}{|c|}{ Experiment $6^{d, f}$} \\
\hline Day 1 & $\begin{array}{l}0.94 \\
( \pm .03)\end{array}$ & $\begin{array}{c}0.53 \\
( \pm .05)\end{array}$ & -- & - & $\begin{array}{c}0.53 \\
( \pm .04)\end{array}$ & $\begin{array}{c}0.41 \\
( \pm .03)\end{array}$ & -- & & \\
\hline Day 2 & $\begin{array}{l}0.51 \\
( \pm .03)\end{array}$ & 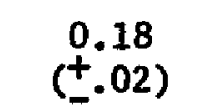 & - & -- & $\begin{array}{c}0.18 \\
( \pm .02)\end{array}$ & $\begin{array}{c}0.17 \\
( \pm .02)\end{array}$ & $\cdots$ & $<0.01$ & 0.24 \\
\hline
\end{tabular}




\begin{tabular}{|c|c|c|c|c|c|c|c|c|c|}
\hline Day 3 & $\begin{array}{l}0.40 \\
( \pm .01)\end{array}$ & $\begin{array}{c}0.14 \\
( \pm .05)\end{array}$ & - & - & $\begin{array}{c}0.09 \\
( \pm .04)\end{array}$ & $\begin{array}{c}0.10 \\
( \pm .04)\end{array}$ & - & & \\
\hline
\end{tabular}

\section{Legend}

a Standard deviation calculated from the relative standard deviations based on sampling error.

b $32 \mathrm{P}-1$ abeled males fed with $12.2 \mathrm{mM}\left[2-{ }^{3} \mathrm{H}\right] \mathrm{EMS}$ (355 mCi/mM specific activity).

c ${ }^{32} \mathrm{P}-1$ abeled males fed with $0.38 \mathrm{mM}\left[1-^{3} \mathrm{H}\right] \mathrm{EMS}$ ( $6100 \mathrm{mCi} / \mathrm{mM}$ specific activity).

d ${ }^{32} \mathrm{p}$-labeled males vapor treated with $0.2 \mathrm{mg}$ [1-3H]EMS (6100 mCi/mM specific activity).

e Egg samples collected without carbon dioxide gas.

E Egg samples collected with carbon dioxide gas.

$g \quad \mathrm{P}_{1}$ is the probability level for the null hypothesis that the ${ }^{3} \mathrm{H} /{ }^{32} \mathrm{P}$ ratio in the sperm are equal to the $3 \mathrm{H} / 32 \mathrm{P}$ ratio in all embryo stages based on an F-test ANOVA.

h $P_{2}$ is the probability level for the null hypothesis that the ${ }^{3} \mathrm{H} /{ }^{32} \mathrm{P}$ ratio in all embryo stages are equal based on an F-test ANOVA. 
TABLE II. ANALYSIS OF VARIANCE FOR ${ }^{3}$ H/ ${ }^{32}$ P RATIO IN SPERM CELLS AND 180-MINUTE EMBRYOS FROM EXPERIMENTS 1 TO 5.

(The treatments are ${ }^{3 \mathrm{H} /} /{ }^{32} \mathrm{P}$ in sperm cells versus the $180-$ minute embryos, while the blocks are the separate experiments.)

\begin{tabular}{|c|c|c|}
\hline & $\begin{array}{l}\text { Sperm } \\
\text { Cells }\end{array}$ & $\begin{array}{c}\text { Gastrula } \\
\text { (180-M1nute Embryos) }\end{array}$ \\
\hline Experiment 1 & $\begin{array}{l}0.5142 \\
\frac{0.6245}{1.1387}=s_{11}\end{array}$ & $\begin{array}{l}0.2237 \\
\frac{0.0959}{0.3196}=s_{12}\end{array}$ \\
\hline ExperIment 2 & $\begin{array}{l}1.1470 \\
\frac{0.3880}{1.5350}=S_{21}\end{array}$ & $\begin{array}{l}0.1046 \\
\frac{0.1035}{0.2081}=s_{22}\end{array}$ \\
\hline Experiment 3 & $\begin{array}{l}1.3820 \\
\frac{1.2758}{2.6578}=s_{31}\end{array}$ & $\begin{array}{l}0.1833 \\
\frac{0.1661}{0.3494}=s_{32}\end{array}$ \\
\hline Experiment 4 & $\begin{array}{l}5.5702 \\
2.1232 \\
7.6934\end{array}=s_{41}$ & $\begin{array}{l}1.1293 \\
\frac{0.1847}{1.3140}=s_{42}\end{array}$ \\
\hline Experiment 5 & $\begin{array}{l}0.3195 \\
\frac{0.2971}{0.6166}=S_{51} .\end{array}$ & $\begin{array}{l}0.0777 \\
\frac{0.0353}{0.1130}=s_{52}\end{array}$ \\
\hline
\end{tabular}

ANOVA TABLE

\begin{tabular}{lccccc}
\hline & $\begin{array}{l}\text { Degrees } \\
\text { of } \\
\text { Freedom }\end{array}$ & $\begin{array}{l}\text { Sum of } \\
\text { Squares }\end{array}$ & $\begin{array}{c}\text { Mean } \\
\text { Square }\end{array}$ & F-test & Probability \\
\hline Tource & 19 & 30.1419 & & & \\
Stage & 1 & 6.3475 & 6.3475 & 9.4612 & P $<.025$ \\
$\begin{array}{l}\text { Experi- } \\
\text { ment }\end{array}$ & 4 & 11.2554 & 2.6139 & 3.8967 & P $<.05$ \\
$\begin{array}{l}\text { Experi- } \\
\text { ment } x \text { stage }\end{array}$ & 4 & 5.8300 & 1.4575 & 2.1724 & NS \\
Error & 10 & 6.7090 & 0.6709 & & \\
\hline
\end{tabular}


the 180-minute embryos. This difference was due to a reduction of the $3_{\mathrm{H} / 32 \mathrm{P}}$ ratios in the embryo samples. The ANOVA also indicated a block (experiment) effect $(P<0.05)$, but this difference between experiments can be attributed to different levels of labeling resulting from the different methods of administering the EMS and the differences in the specific activities of the ${ }^{3}$ H-EMS samples used in the experiments (Table 1). There was no significant experiment-treatment interaction Indicating that all five experiments were consistent in showing a atatistically significant decrease in the ${ }^{3} \mathrm{H} /{ }^{32} \mathrm{P}$ ratios between sperm and the 180-minute embryo stage.

In experiments three, four and flve, embryos were sampled at earlier stages to determine when during embryogenesis the events which cause the reduction in the ${ }^{3} \mathrm{H} /{ }^{32} \mathrm{P}$ ratio occur. When the ratios of the DNA samples from experiments three through five were compared, there was no significant difference between early and late embryos, but there was a significant difference between the sperm and embryo samples (Table 1). This Indicates that the events which caused the reduction in the ${ }^{3} \mathrm{H} /{ }^{32} \mathrm{P}$ ratio occurred early during embryogenesis, possibly as early or earlier than the first embryo stages sampled. The probability levels $\left(P_{1}\right.$ and $\left.P_{2}\right)$ given in the last two columns of Table 1 are based on experimental error from the analysis of variance and are a more conservative estimate of the difference between sperm cells and embryos than the confidence limits of the ${ }^{3} \mathrm{H} /{ }^{32} \mathrm{P}$ ratios in Table 1 which are based only on sampling error of the counting statistics.

A group of inseminated females from each mating in experiment five were set aside to Investigate the effect of sperm storage on the ${ }^{3} \mathrm{H} /$ ${ }^{32} \mathrm{P}$ ratio in the sperm. The sperm cells in these females were sampled 
Immediately after mating, 3 days after mating and 7 days after mating. Comparison of the ratios from the DNA extracts of the stored and nonstored spermatozoa suggested there was a time dependent decrease of 3H-1abeled ethy1 groups in the stored sperm (Table IV).

Experiment six was designed to test both the stage effect (sperm vs. embryos) and the apparent storage effect observed In the stored sperm of experiment five. One thousand labeled CD males were treated with 3 H-EMS vapor and mated to 3400 virgin $Q$ females. Nine hundred of these females were selected at random and set aside for sperm sampling. Sperm samples from the inseminated females were collected on each of the 3 days during which the embryos were collected. Embryo samples were pooled each day according to embryonic stage. The comparison of the ${ }^{3} \mathrm{H} /{ }^{32} \mathrm{P}$ ratios of the sperm DNA to embryo DNA was done using a randomized block design where treatments consisted of sperm cells, premitotic embryos (15-minute samples), second division embryos (30-minute samples) and gastrula embryos (180-minute samples). The samples were blocked according to the day (Day 1, Day 2, or Day 3) on which they were taken (Table III). Therefore, the variance can be partitioned into the component due to treatment differences (sperm vs. embryo stages) and the component, if any, due to storage differences.

The analysis of variance for experiment six showed a significant treatment effect $(p<0.01)$ and slgnificant block (storage) effect $(p<0.01)$. The treatment effect was due entirely to the difference of ${ }^{3} \mathrm{H} /{ }^{32} \mathrm{P}$ ratios between the sperm cells and the embryos. This result was consistent with the results of the previous experiments. The difference among embryo samples was not significant; however, the sperm cells had a significantly larger ratio than any embryo sample. This indicates 
TABLE III. THE ANALYSIS OF VARIANCE FOR ${ }^{3} \mathrm{H}^{32} \mathrm{P}$ RATIOS FROM EXPERIMENT 6 .

\begin{tabular}{lllll}
\hline & $\begin{array}{c}\text { Premitotic } \\
\text { Sperm } \\
\text { Ce118 }\end{array}$ & $\begin{array}{c}\text { Embryos } \\
(\text { I5 min) }\end{array}$ & $\begin{array}{c}\text { 2nd division } \\
\text { cleavage } \\
\text { Embryos } \\
(30 \text { min) }\end{array}$ & $\begin{array}{l}\text { Gastrula } \\
\text { Embryos } \\
\text { (180 min) }\end{array}$ \\
\hline Day 1 & 0.9418 & 0.5292 & 0.3524 & 0.4053 \\
Day 2 & 0.5052 & 0.1795 & 0.1768 & 0.1745 \\
Day 3 & 0.4037 & 0.1375 & 0.0895 & 0.1034 \\
\hline
\end{tabular}

ANOVA TABLE

\begin{tabular}{lccccc}
\hline Source & $\begin{array}{c}\text { Degrees of } \\
\text { Freedom }\end{array}$ & $\begin{array}{c}\text { Sum of } \\
\text { Squares }\end{array}$ & $\begin{array}{c}\text { Mean } \\
\text { Squares }\end{array}$ & F-test & $\begin{array}{c}\text { Proba- } \\
\text { b111ty }\end{array}$ \\
\hline Total & 11 & 0.7094 & & & \\
Day & 2 & 0.3984 & 0.1992 & 68.3 & $<.01$ \\
Stage & 3 & 0.2935 & 0.0978 & 33.5 & $<.01$ \\
$\begin{array}{l}\text { Sperm v8. } \\
\text { Embryos }\end{array}$ & 1 & 0.2887 & 0.2887 & 99.6 & $<.01$ \\
$\begin{array}{l}\text { Gastrula vs. } \\
\text { Earlier Stages }\end{array}$ & 1 & 0.0043 & 0.0043 & 1.5 & NS \\
$\begin{array}{l}\text { Premitotic v8. } \\
\text { 2nd Division } \\
\text { Embryos }\end{array}$ & 1 & 0.0004 & 0.0004 & 0.2 & NS \\
$\begin{array}{l}\text { Error } \\
\text { End }\end{array}$ & 6 & 0.0175 & 0.0029 & & \\
\hline
\end{tabular}


TABLE IV. THE ${ }^{3} \mathrm{H} /{ }^{32} \mathrm{P}$ RATIOS FROM STORED AND NON-STORED 3 H-EMS TREATED DROSOPHIIAA SPERMATOZOA

\begin{tabular}{|c|c|c|c|c|c|}
\hline & Mating & $\begin{array}{c}\text { Day } 1 \\
\text { (Non-8tored) }\end{array}$ & Day 2 & Day 3 & Day 7 \\
\hline \multirow[t]{2}{*}{ Experiment 5} & 1 & $\begin{array}{r}0.3195^{\mathrm{a}} \\
( \pm .09)\end{array}$ & $-\infty$ & $\begin{array}{l}0.1499 \\
( \pm .02)\end{array}$ & $\begin{array}{l}0.0583 \\
( \pm .01)\end{array}$ \\
\hline & 2 & $\begin{array}{r}0.2971 \\
( \pm .03)\end{array}$ & -- & $\begin{array}{l}0.1573 \\
( \pm .04)\end{array}$ & $\begin{array}{l}0.10 \\
( \pm .01)\end{array}$ \\
\hline \multirow[t]{2}{*}{ Experiment 6} & 1 & $\begin{array}{r}0.9418 \\
( \pm .09)\end{array}$ & $\begin{array}{r}0.5052 \\
( \pm .03)\end{array}$ & $\begin{array}{r}0.4037 \\
( \pm .02)\end{array}$ & $-\infty$ \\
\hline & 2 & $\begin{array}{l}0.7191 \\
( \pm .04)\end{array}$ & $\begin{array}{r}0.6638 \\
( \pm .03)\end{array}$ & $\begin{array}{l}0.6462 \\
( \pm .03)\end{array}$ & -- \\
\hline
\end{tabular}

astandard deviation calculated from the relative standard deviatiotis based on sampling error. 
that the change in the ${ }^{3} \mathrm{H} /{ }^{32} \mathrm{P}$ ratio must have occurred earlier than 15 minutes after deposition of the egg. The storage effect was due to the decrease in the ${ }^{3} \mathrm{H} /{ }^{32} \mathrm{P}$ ratios of both sperm and embryos sampled on consecutively later days. This storage effect might be attributed to a time dependent loss of ethyl groups from the DNA of sperm cells stored in the seminal receptacle.

Stab1lity of Alkyl Groups in the Sperm

Table IV shows the ${ }^{3} \mathrm{H} /{ }^{32} \mathrm{P}$ ratios of DNA extracts from the stored and non-stored sperm samples from experiments five and six. A comparison of the ${ }^{3 \mathrm{H}} /{ }^{32} \mathrm{P}$ ratios from these four sperm samples indicates that there is a consistent time dependent reduction in the isotopic ratio with sperm cell storage.

Percentage of ${ }^{3} \mathrm{H}$ Retained in the Stored Sperm and Embryos

If the ${ }^{3} \mathrm{H} /{ }^{32} \mathrm{P}$ ratio of the non-stored sperm samples are considered unity, then the ratios from the stored sperm samples can be expressed as a percentage of the non-stored sample using the formula:

$$
3_{\mathrm{H} \%}=\frac{3_{\mathrm{H} /}{ }^{32} \mathrm{P} \text { stored samples }}{3_{\mathrm{H} /} /{ }^{32} \mathrm{P} \text { non-stored samples }} \times 100
$$

In a similar manner the ${ }^{3} \mathrm{H} /{ }^{32} \mathrm{P}$ ratios of the embryo samples can be expressed as a percent of the sperm samples. The $108 s$ of ${ }^{32} \mathrm{P}$ in the spern cells and embryos is due to radioactive decay and since a correction is made for the decay in computing ${ }^{32} \mathrm{P} \mathrm{dpm}$, the ${ }^{32} \mathrm{P}$ terms in the numerator and denominator should cancel and the percentage obtained will approximate the percent of tritiated ethyl groups retained in the stored sperm 
and the embryo samples.

One mechanism which accounts for loss of alkyl groups in DNA is exclston repair (Regan and Setlow, 1973; Roberts et al., 1968 and 1971). If alkylated bases are removed by an exclsion repair, some of the ${ }^{32} \mathrm{P}$ atoms In the DNA backbone may also be lost. Regan and Setlow (1973) estimate that repair due to EMS damage 1nvolves the replacement of two to three nucleotides. The sperm derived DNA is randomly labeled with ${ }^{32} \mathrm{p}$ and the level of ${ }^{32} \mathrm{P}$ labeling on the sperm DNA 1s approximately $4.7 \times 10^{-6} 32 \mathrm{P}$ atoms per nucleotide. If the selective recognition and elimination of an ethyl group involves replacement of three bases the highest rate of removal of ${ }^{32} \mathrm{P}=3\left(4.7 \times 10^{-6}\right)=1.4 \times 10^{-5}$. Even if the excision of an ethylated base involves removal of 104 nucleotides as estimated by Roberts et al. (1968 and 1971), the highest rate of $108 \mathrm{~s}$ of $32 \mathrm{P}$ is only $4.9 \times 10^{-4}$. Therefore, a decrease in the $3_{\mathrm{H} / 32 \mathrm{P}}$ ratio indicates a selective removal of ethyl groups which exceeds the 1oss of the randomly labeled ${ }^{32} \mathrm{P}$. Such a decrease would be effected by excision repair but would not be effected by changes in the efficiency of DNA extraction.

The majority of EMS Induced alkylations on DNA occur at the $\mathrm{N}-7$ position of guanine and $\mathrm{N}-3$ position of adenine (Sun and Singer, 1975; Lawley and Brookes, 1963). It has been shown that more than $50 \%$ of the ethy1 groups on the bases of ethylated sperm cell DNA co-chromatograph with 7-ethyl guanine (Aaron et al., 1973). Therefore, it is assumed that the majority of ${ }^{3} \mathrm{H}$ labeling of alkylated sperm DNA occurs at these sites. Approximately $15 \%$ of the ethylations are expected to occur on the DNA phosphates (Bannon and Verly, 1972), however, the phosphotrlesters formed by alkylation of the DNA phosphates are stable and are not ex- 
pected to contribute significantly to a reduction in the alkylation of ethylated DNA.

Strauss et al., (1975) has calculated the overall rate constant for hydrolytic depurination of 7-alkyl guanine and 3-alkyl adenine from aj.kylated DNA. This constant is based on the methylated DNA products which are slightly less stable than the ethylated products (Strauss and H111, 1970). Assuming that this constant $\left(1.84 \times 10^{-4} \mathrm{~min}^{-1}\right)$ also approximates the hydrolytic 108 of the ethylated products; the observed reduction of ethylation in the stored sperm cells and in the embryos can be compared to the reduction expected from hydrolysis of alkylated purines.

The semt-log plot for $3^{3} \%$-retained by sperm cells over the storage period is 111 ustrated in Figure 4. All four series of sperm samples show at least a $10 \%$ decrease of $3_{\mathrm{H}}$ label during the storage period. Rate constants (Table V) based on the observed decrease were computed by regressing the $\log _{e} N / N_{0}$ (dependent varlable) with the negative time of storage (independent varlable) such that;

$$
\text { where: } \begin{aligned}
k & =\frac{\operatorname{Loge}_{e} / N_{0}}{-t i m e}=b_{0}=\text { the slope of the regression, } \\
\mathrm{n} & =3_{\mathrm{H}} \% \text { after storage } \\
\mathrm{n}_{\mathrm{o}} & =3_{\mathrm{H}} \% \text { before storage } \\
\mathrm{t} & =\text { time elapsed in minutes. }
\end{aligned}
$$

The observed rates of reduction of ethyl groups in the stored sperm do not differ greatly from the rate expected if this loss is due to spontaneous hydrolysis of alkylpurines from DNA. 


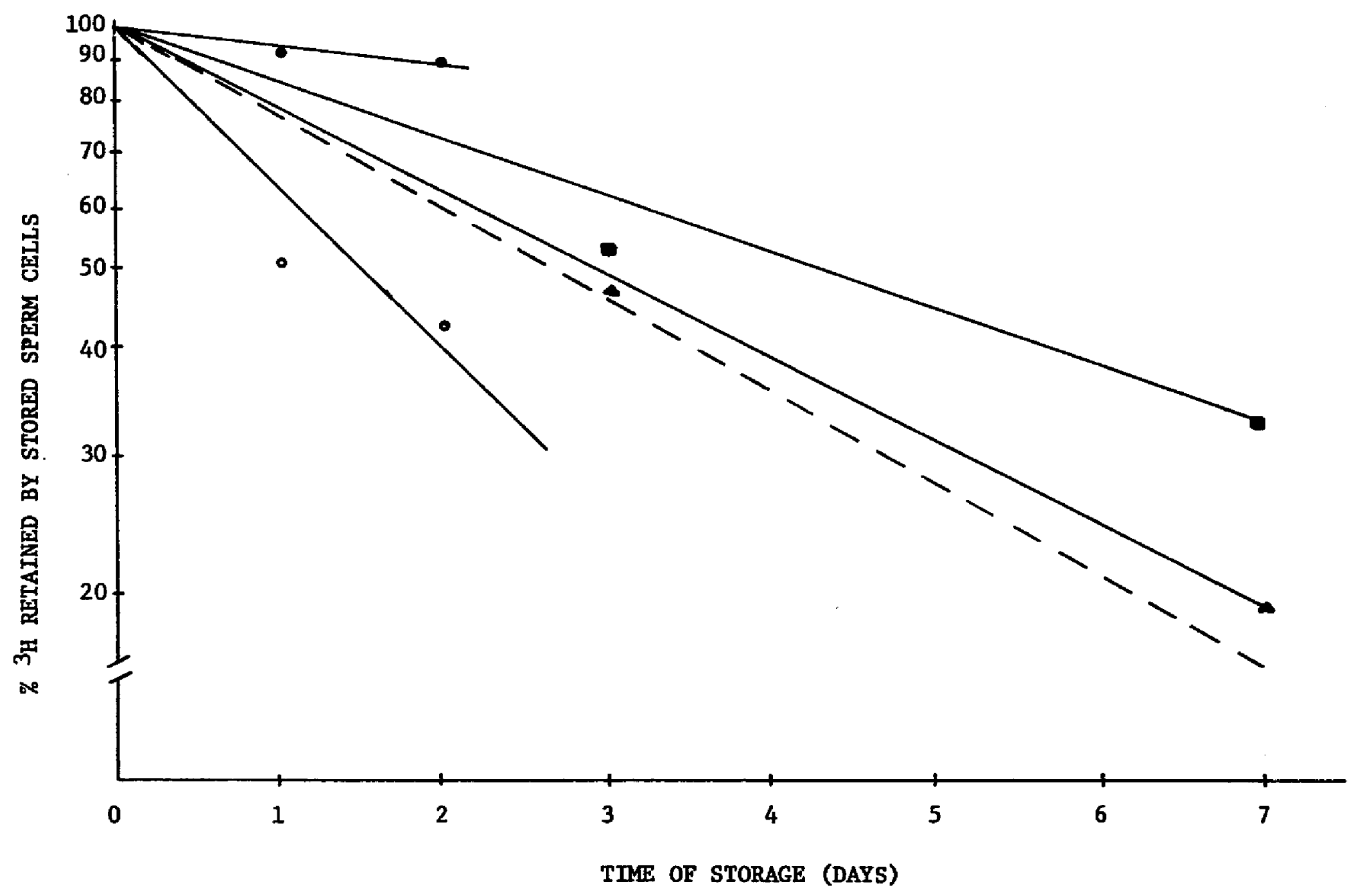

Figure 4. The Reduction of 3 H-Label After Sperm Storage. Experiment 5 Mating 1 - ; Experiment 5 Mating 20 ; Experiment 6 Mating 10 ; Experiment 6 Mating 20 ; Hydrolytic depurination of alkyl purines ---. 
TABLE V. THE CALCULATED RATES FOR ${ }^{3} \mathrm{~B} /{ }^{32} \mathrm{P}$ REDUCTION IN STORED SPERM CELLS

\begin{tabular}{|c|c|c|c|c|c|c|}
\hline \multicolumn{2}{|c|}{ Experiment } & $\begin{array}{c}\text { Time } \\
\text { (minutes) }\end{array}$ & $\frac{{ }^{3} \mathrm{H} /{ }^{32} \mathrm{P} \text { Sperm Stored }}{{ }^{{ }_{\mathrm{H}} /{ }^{32} \mathrm{P} \text { Sperm Non-stored }}}$ & $=\mathrm{N} / \mathrm{N}_{\mathrm{o}}$ & $\log _{e} N / N_{0}$ & $k={\frac{\log _{e} N / N_{0}}{-t \text { Ime }}}^{a}$ \\
\hline \multirow{6}{*}{5} & Mate 1 & 0 & 1.00 & & 0.00 & $1.66 \times 10^{-4} \mathrm{~min}^{-1}$ \\
\hline & & 4320 & 0.47 & & -0.75 & (S.E. $2.56 \times 10^{-6} \mathrm{~min}^{-1}$ ) \\
\hline & & 10080 & 0.19 & & -1.66 & \\
\hline & Mate 2 & 0 & 1.00 & & 0.00 & $1.16 \times 10^{-4} \mathrm{~min}^{-1}$ \\
\hline & & 4320 & 0.53 & & -0.63 & (S.E. $9.47 \times 10^{-6} \min ^{-1}$ ) \\
\hline & & 10080 & 0.33 & & -1.11 & \\
\hline \multirow{6}{*}{6} & Mate 1 & 0 & 1.00 & & 0.00 & \\
\hline & & 1440 & 0.54 & & -0.62 & $3.20 \times 10^{-4} \mathrm{~min}^{-1}$ \\
\hline & & 2880 & 0.43 & & -0.84 & (S.E. $3.81 \times 10^{-5} \min ^{-1}$ ) \\
\hline & Mate 2 & 0 & 1.00 & & 0.00 & \\
\hline & & 4320 & 0.92 & & -0.08 & $4.08 \times 10^{-5} \mathrm{~min}^{-1}$ \\
\hline & & 2880 & 0.90 & & -0.11 & (S.E. $6.03 \times 10^{-6} \min ^{-1}$ ) \\
\hline
\end{tabular}

Mean $k=1.61 \times 10^{-4} \min ^{-1} \quad$ Pooled Standard Error $=2.62 \times 10^{-9}$ min $^{-1}$

aThe $k$ value is computed from the regression of three points using a no intercept model for

Iinear regression $(\mathrm{Y}=\mathrm{kX})$. 
F1gure 5 is the semi-1og plots of $3_{H} \%$-retalned by sperm derived DNA of the embryos from Mating 1 of each of the last three experiments. The data from the last three experiments were plotted since only these experiments contain data from three different measurements of the ${ }^{3} \mathrm{H} /{ }^{32} \mathrm{P}$ ratios of closely timed embryos (5-minute age span), and at least three points are necessary for performing a valid regression analysis for the effect of embryonic stage on the level of ${ }^{3} \mathrm{H}$ label (Table VI). Experiment three has three embryo data pointa (Table I) but the last point ( 3 hours to 12 hours) is from a collection of embryos with a 9-hour age span. Since only two of the samples in experiment three have the same age span in the embryo samples (5-minute age span) the data from experiment three was excluded from this regression analyais. To determine the most conservative estimate of the embryonic decrease in the ${ }^{3}$ H label only the data for Mating 1 of experiments four and five and Day 1 from experiment six (Table 1) were plotted since these experimental blocks exhibit the smallest embryonic decrease in $3_{H}$ labeling. Each point on the X-axis represents the minimum age of the embryo sample. As many as $21 \%$ of the embryos in a pooled embryo sample (Table IX) may have been retained for some perlod of time in the uterus of the female and were in more advanced stages of development than the majority of embryos in the sample. The retalned embryos are of particular Importance in the early embryo stages (15 to 30 minutes) since the time interval between stages is small. Therefore, the early embryo stage samples may overlap each other and may not cleanly separate the embryos into the discrete stages indicated previously. The regression lines for experiments four, five, and six, calculated from the three embryo points in each experiment, intercept the Y-axis at $36 \%, 34 \%$, 


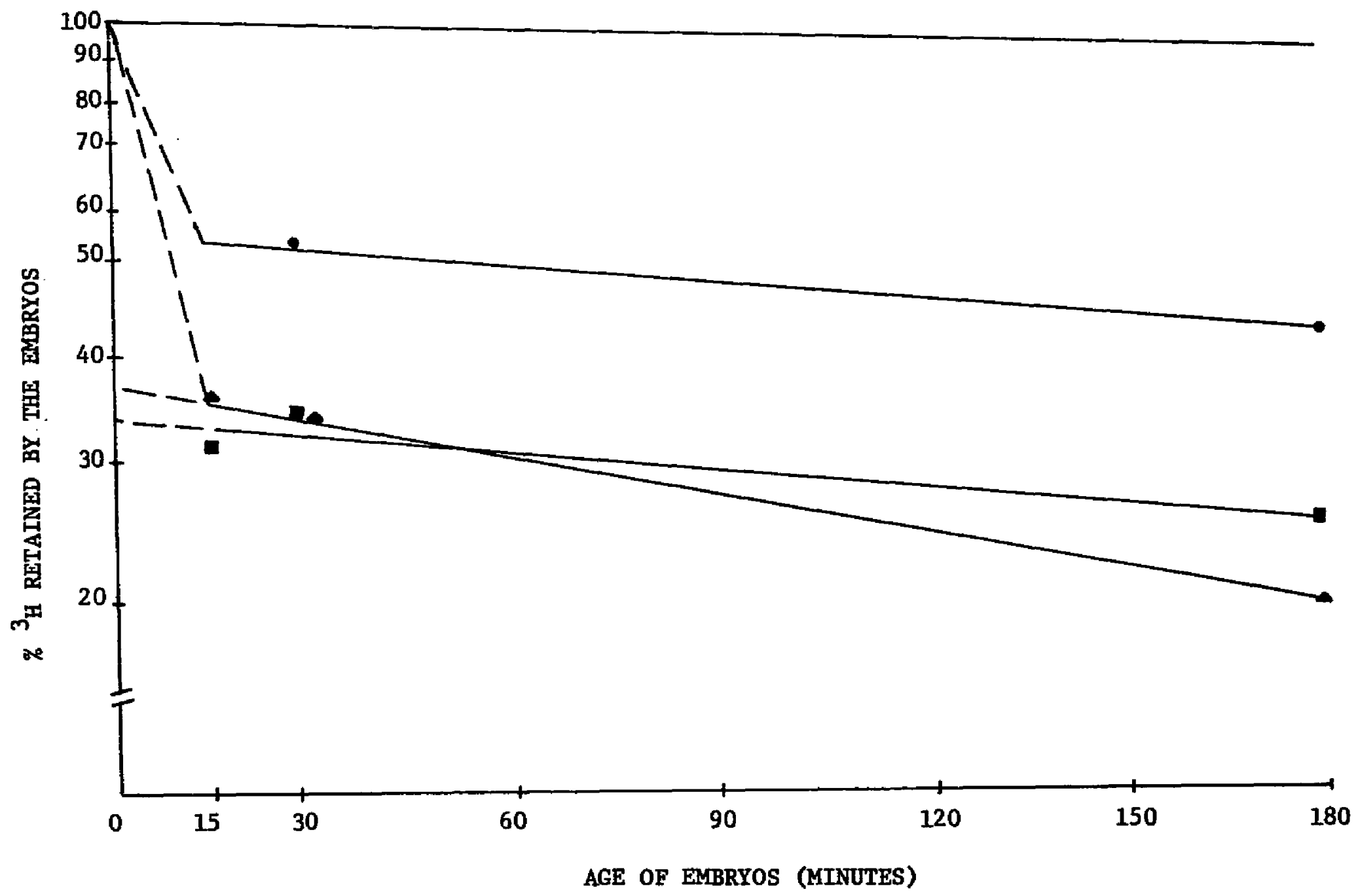

Figure 5. The reduction of $3_{\mathrm{H}-1 \mathrm{abel}}$ from sperm derived DNA during embryonic development. Experiment 4 Mating $1 \star$; Experiment 5 Mating 10 ; Experiment 6 Mating $1 \bullet$; Hydrolytic depurination of alkyl purines 
TABLE VI. THE CALCULATED RATES FOR ${ }^{3}$ H/32P REDUCTION IN THE EMBRYOS DURING EARLY CLEAVAGE AND T-TEST OF THE RATES

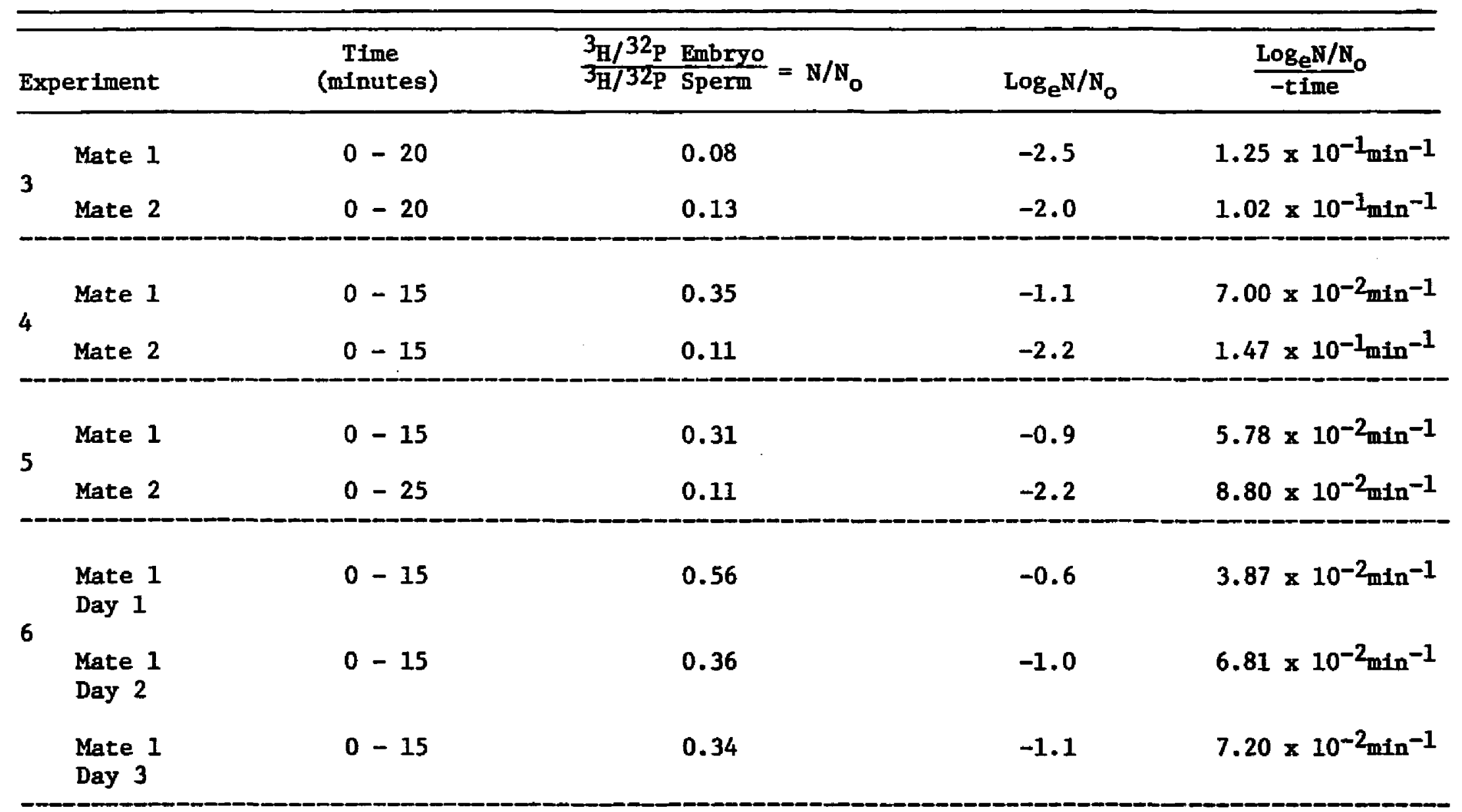


TABLE VI (Continued)

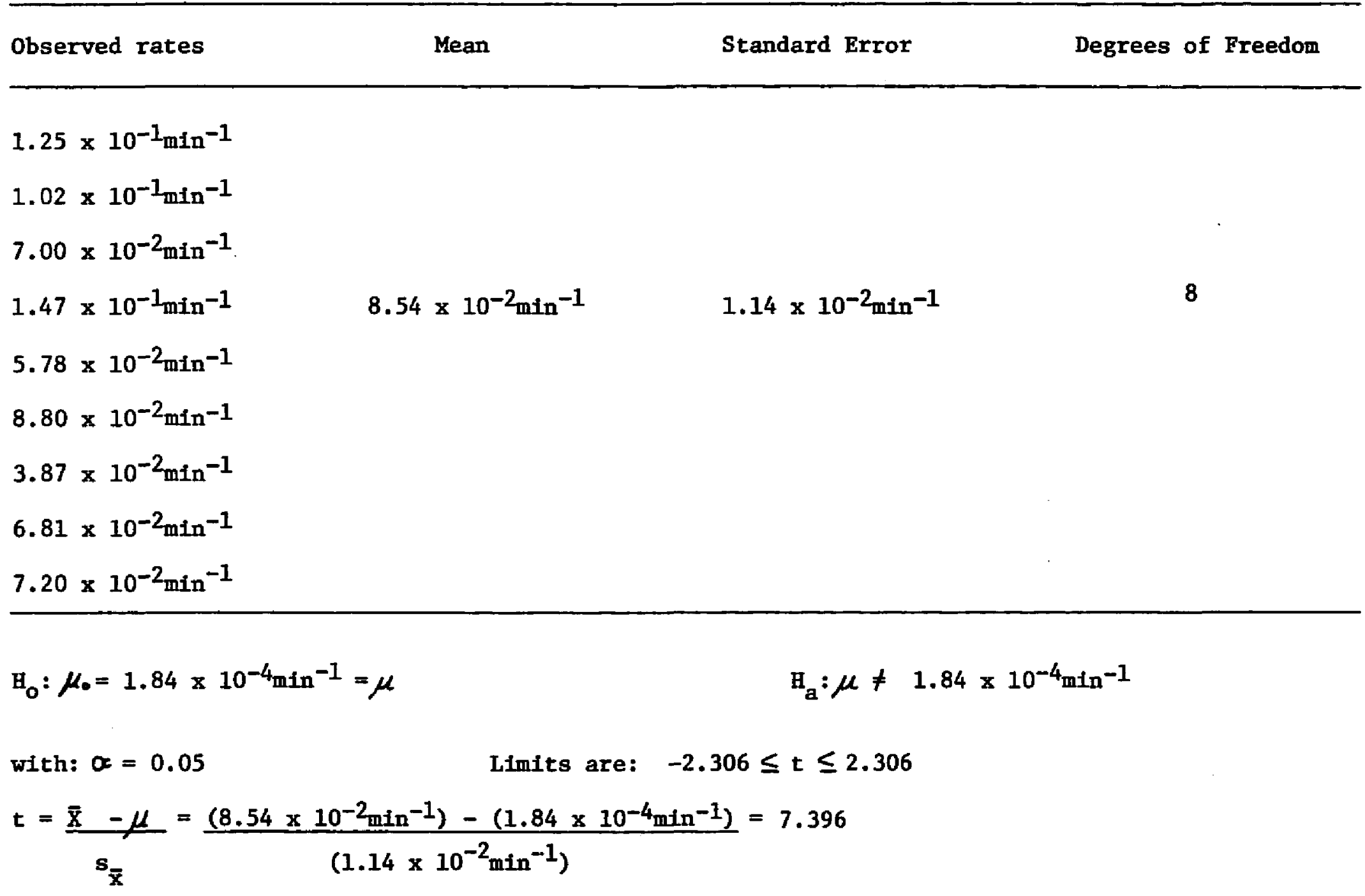


TABLE VI (Continued)

Since $7.396 \geq 2.306$ reject the null hypothesis and assume there is a significant difference between the observed rates of reduction of the ration and the rate of hydrolytic removal of alkylpurines from DNA. $P<.05$. 
TABLE VII. THE CALCULATED RATES FOR ${ }^{3} \mathrm{H} /{ }^{32} \mathrm{P}$ REDUCTION IN THE EMBRYOS DURING LATER STAGES AND T-TEST OF THE RATES.

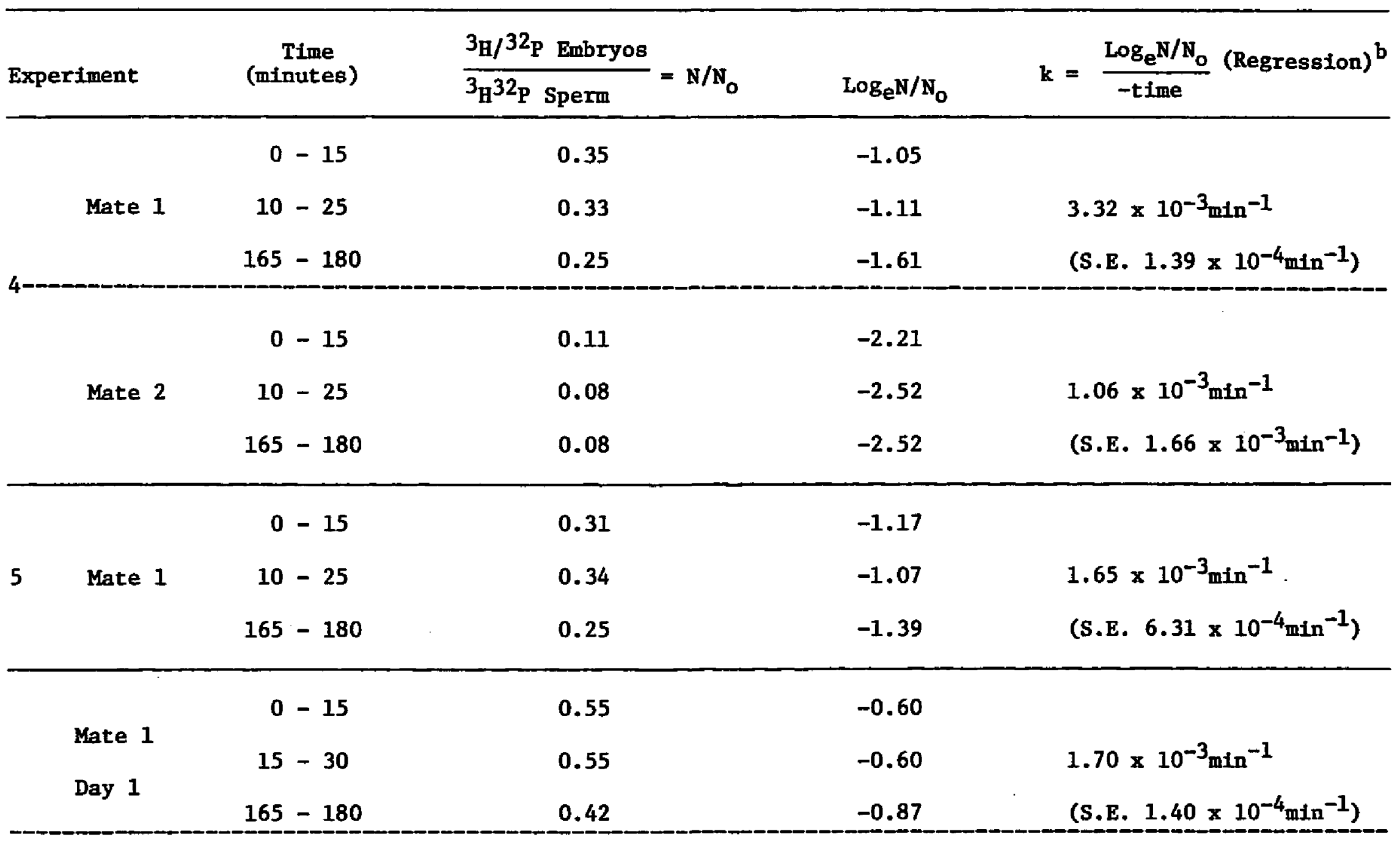


TABLE VII. (Continued)

\begin{tabular}{|c|c|c|c|c|}
\hline ExperIment & $\begin{array}{l}\text { Time } \\
\text { (minutes) }\end{array}$ & $\frac{3_{H} / 32 P \text { Embryos }}{3_{H}^{32} P \text { Sperm }}=N / N_{0}$ & $\operatorname{LogeN} / N_{0}$ & $k=\frac{\log _{e} N / N_{0}}{\text {-time }}(\text { Regression) })^{b}$ \\
\hline $\begin{array}{l}\text { Mate } 1 \\
\text { Day } 2\end{array}$ & $\begin{array}{c}0-15 \\
15-30 \\
165-180\end{array}$ & $\begin{array}{l}0.35 \\
0.35 \\
0.35\end{array}$ & $\begin{array}{l}-1.05 \\
-1.05 \\
-1.05\end{array}$ & 0.00 \\
\hline $\begin{array}{l}\text { Mate } 1 \\
\text { Day } 3\end{array}$ & $\begin{array}{c}0-15 \\
15-30 \\
165-180\end{array}$ & $\begin{array}{l}0.36 \\
0.21 \\
0.29\end{array}$ & $\begin{array}{l}-1.02 \\
-1.56 \\
-1.24\end{array}$ & $\begin{array}{l}-7.21 \times 10^{-5} \min ^{-1} \\
\text { (S.E. } 2.97 \times 10^{-3} \min ^{-1} \text { ) }\end{array}$ \\
\hline
\end{tabular}

a Rates calculated only in those matings where 3 observations were made.

b The $k$ value is computed using intercept model for linear regression $(Y=a+k X)$.

$\begin{array}{llll}\text { Observed rates } & \text { Mean } & \text { Standard Error } & \text { Degrees of Freedom }\end{array}$

$3.32 \times 10^{-3} \mathrm{~min}^{-1}$

$1.06 \times 10^{-3} \min ^{-1}$ 
TABLE VII. (Continued)

Observed rates

Degrees of Freedom

$1.65 \times 10^{-3} \mathrm{~min}^{-1}$

$1.70 \times 10^{-3} \min ^{-1}$

$1.30 \times 10^{-3} \min ^{-1} \quad 5.16 \times 10^{-4} \min ^{-1}$

$0 \min ^{-1}$

$-7.21 \times 10^{-5} \min ^{-1}$

$\mathrm{H}_{0}: \mu_{0}=1.84 \times 10^{-4} \min ^{-1}=\mu \quad \mathrm{H}_{\mathrm{a}}: \mu \neq 1.84 \times 10^{-4} \min ^{-1}$

with: $\propto=0.05 \quad$ limits are: $-2.571 \leq t \leq 2.571 \subset \quad 5 \mathrm{df}$

$t=\frac{\bar{x}-\mu}{s_{\bar{x}}}=\frac{\left(1.30 \times 10^{-3} \min ^{-1}\right)-\left(1.84 \times 10^{-4} \min -1\right)}{\left(5.16 \times 10^{-4} \min ^{-1}\right)}=2.12$

Since $-2.571 \leq 2.12 \leq 2.571$, fail to reject the null hypothesis and conclude that there is no significant difference between the observed slow rates of reduction of the ratio and the rate of hydrolytic removal for alkylpurines from DNA $(p<0.05)$. 
and $57 \%$, respectively. The semi-log plots of the decrease in ${ }^{3} \mathrm{H}$ and the calculated $Y$-intercept values all project a rapid initial decrease (Table VI) In the level of ${ }^{3} \mathrm{H}$ label. However, the magnitude of this Inttial decrease differs between all experiments. This difference between experiments is due to differences such as in the method of administering the EMS, in the specific activities of the ${ }^{3} \mathrm{H}-\mathrm{EMS}$ samples, In the type of virgins used for egg collections, etc., but there is no clear pattern to indicate which of the differences influence the magnitude of the initial decrease.

There is a statistically significant difference between the embryonic rates of $108 s$ observed prior to the flrst embryo stages sampled and the rate of spontaneous hydrolytic depurination (Table VI), but there is no significant difference between the observed mean rates of $3_{\mathrm{H}}$ loss and the rate for hydrolytic depurination of alkylated DNA in the later embryo stages (Table VII). This suggests that between fertilization of the egg and the first or second mitotic division in the embryo, ethyl groups are lost at a rate much greater than the rate for hydrolytic depurination. During this period the alkyl groups are lost at least 400 times faster than would be expected by spontaneous hydrolysis. After the first few mitotic divisions in the early embryo ${ }^{3}$ H loss approximates the rate for hydrolytic 10 ss of alkylpurines.

Fertility of Embryos Collected with Carbon Dioxide Gas

When this series of experiments were inftially designed it was expected that eggs would be collected by simply allowing the inseminated females to lay on a media specially prepared to induce egg laying (Würgler et al., 1968). This method of egg collection worked well for 
the first two experiments in which the earliest embryo samples were three to four hours old (gastrula stage). In these first experiments the females could be left to lay eggs undisturbed for at least one hour. Thus, large groups of eggs having approximately the same embryonic development could be collected easily. In the remaining four experiments it was necessary to collect egg samples over shorter time Intervals and to reduce the age range of embryos in each sample. The normal egg laying rate of the inseminated females was not sufficient to allow collection of large numbers of closely timed embryos. It was proposed that these more closely times samples could be collected by using anesthetizing doses of carbon dioxide gas to induce egg laying by the inseminated females.

Since the experiments are designed to investigate embryonic events it is important that the collected eggs be fertilized. Thus, it was necessary to determine how the $\mathrm{CO}_{2}$ treatment affected the fertility of the sampled eggs. This affect of $\mathrm{CO}_{2}$ on egg fertility was measured in six independent determinations, In which separate groups of 200300 inseminated 4-6 day old female flfes were used for each determination. The Inseminated females were allowed to deposit eggs over onehour periods on the spectal medla of Wïgler et al., (1968). Samples taken prior to $\mathrm{CO}_{2}$ subjection served as controls. After a sufficient number of control eggs were collected the females were administered anesthetizing doses of $\mathrm{CO}_{2}$ to induce egg deposition. The females were allowed to recover from the affects of $\mathrm{CO}_{2}$ for at least one hour before being anesthetized again. Twenty-four hours after deposition the eggs from both the control and $\mathrm{CO}_{2}$ groups were scored for hatchability (Table VIII). 
TABLE VIII. THE EGG FERTILITY USING CARBON DIOXIDE GAS TO INDUCE EGG LAYING

\begin{tabular}{|c|c|c|c|c|c|c|}
\hline \multirow[b]{2}{*}{ Determination } & \multicolumn{3}{|c|}{ Control } & \multicolumn{3}{|c|}{$\mathrm{CO}_{2}$ Group } \\
\hline & $\begin{array}{l}\text { No. } \\
\text { Eggs }\end{array}$ & $\begin{array}{c}\text { No. } \\
\text { Hatch }\end{array}$ & $\frac{7}{\text { Hatch }}$ & $\begin{array}{l}\text { No. } \\
\text { Egg8 }\end{array}$ & $\begin{array}{c}\text { No. } \\
\text { Hatch }\end{array}$ & $\frac{7}{\text { Hatch }}$ \\
\hline 1 & 420 & 359 & 85.5 & 571 & 383 & 67.1 \\
\hline 2 & 110 & 101 & 91.8 & 158 & 120 & 75.9 \\
\hline 3 & 174 & 153 & 87.9 & 583 & 375 & 64.3 \\
\hline 4 & 152 & 123 & 80.9 & 707 & 408 & 57.7 \\
\hline 5 & 255 & 230 & 90.2 & 583 & 362 & 62.1 \\
\hline 6 & 528 & 497 & 94.1 & 509 & 408 & 80.2 \\
\hline 8 & & & 88.4 & & & 68.0 \\
\hline SD & & & 4.7 & & & 8.4 \\
\hline
\end{tabular}


The mean hatchability for the control eggs combining all of the determinations was $88 \%$. $( \pm 5 \% \mathrm{SD})$. The mean hatchability of the embryos In the $\mathrm{CO}_{2}$ group was $68 \%( \pm 8 \% \mathrm{SD})$. Since the majority of the eggs collected with $\mathrm{CO}_{2}$ were fertile it was decided that further studies could be carried out using $\mathrm{CO}_{2}$ to collect timed egg samples. Eggs that are not fertilized do not contribute either one of the radionuclides to the DNA extracts and therefore do not affect the ${ }^{3} \mathrm{H} /{ }^{32} \mathrm{P}$ rat1os.

Percent of Retained Eggs In Pooled Embryo Samples

Normally, the egg passes into the uterus where it is fertilized by a spermatozoa and the egg is deposited on the media soon after. These two events occur in a very short pertod of time such that embryonic development is considered to begin when the egg is deposited. Sometimes a female may retain an inseminated egg in the uterus for a period of time. Such an egg begins embryonic development within the female and is deposited In an advanced developmental stage (würgler et al., 1968). Durlng these experiments an attempt was made to separate the early embryo samples into distinct developmental stages (premitotic, 15 minutes after deposition; first cleavage division, 20 and 25 minutes after deposition; and second division, 30 minutes after deposition) based on the time schedule of Rabinowitz (1941). Thus it is Important to determine what proportion of the embryos are retained from one stage to the next.

As described in the Methods and Materials embryos from each stage were selected at random and prepared for cytological examination. The description of early cleavage for Drosophlla melanogaster given by Sonnenblick (1965) was used as a cytological guide for determining the 
developmental stage of a particular embryo. Approximately $1 \%$ of the total egg sample from any particular developmental atage was prepared for cytological examination and these embryos were selected at random from approximately $16 \%$ of the egg amples pooled for a particular developmental stage. Table IX gives the results of cytological examinatlons of embryos from seven different groups of pooled egg samples distributed among four different experiments. Assuming that the proportion of retained eggs in a pooled sample is not dependent on what stage the eggs have reached when development 18 stopped or in what experiment the samples are collected, a mean value based on all seven obgervations can be computed. Among the seven groups of pooled embryo somples the overall mean of retained eggs in the cytological samples 18 $8 \%( \pm 6 \% \mathrm{SD})$. Since on the average only $68 \%$ of the embryos collected are fertile it can be expected, based on cytological examination that as many as 21\% of the fertile embryos in a pooled sample may have come from fertilized eggs that had been retained in the uterus of the female. The observation that there might be overlap between embryo stages must be considered when comparing the ${ }^{3} \mathrm{H} /{ }^{32} \mathrm{P}$ ratlos obtained from the various embryonic stages.

The Effect of DNA Source on the Extraction Procedure

The DNA in the sperm cells is bounded by arginine-rich histones, tightly coiled, and in a non-metabolizing condition, while the operm derived DNA of the embryo is bounded by lysine-rich histones, is not as tightly coiled as the DNA in the sperm cells, and 1s capable of metabollc activity (Das, et al., $1964 \mathrm{a}$ and 1964b; Oliverl and Oliver1, 1965; Brink, 1968). Since the DNA of the sperm to packaged differently 
TABLE IX. THE PERCENTAGE OF EMBRYOS RETAINED BEYOND THE STAGE SAMPLED

\begin{tabular}{|c|c|c|c|c|c|}
\hline Experiment & $\begin{array}{l}\text { Average age } \\
\text { of eggs in } \\
\text { the pooled } \\
\text { sample (min) }\end{array}$ & $\begin{array}{l}\text { No, eggs in } \\
\text { the pooled } \\
\text { sample }\end{array}$ & $\begin{array}{l}\text { No. eggs } \\
\text { cytologically } \\
\text { examined }\end{array}$ & $\begin{array}{l}\text { No. re- } \\
\text { tained } \\
\text { eggs }\end{array}$ & $\begin{array}{l}\text { Percent }^{a} \\
\text { retained } \\
\text { eggs }\end{array}$ \\
\hline \multirow[t]{2}{*}{4} & 15 & 3675 & 37 & 3 & 8.1 \\
\hline & 25 & 3626 & 44 & 2 & 4.5 \\
\hline \multirow[t]{2}{*}{5} & 15 & 6055 & 40 & 1 & 2.5 \\
\hline & 25 & 6397 & 24 & 0 & 0.0 \\
\hline \multirow[t]{2}{*}{6} & 15 & 7600 & 64 & 8 & 13.0 \\
\hline & 30 & 8992 & 52 & 6 & 12.0 \\
\hline 7 & 30 & 4175 & 37 & 6 & 16.2 \\
\hline
\end{tabular}

a $\overline{\mathrm{X}}$ for the percent of embryos retained equals $8 \pm 6$ standard deviation.

b Experiment 7 sample is from the 3 H-MMS treatment used to determine the efficiency of the extraction procedure for the two types of DNA sources. 
than the sperm derived DNA of the embryo it is possible that the DNA extraction procedure has a differential effect on DNA from the two different sources. It might be suggested that a differential effect of the DNA extraction procedure 18 responsible for the apparent reduction

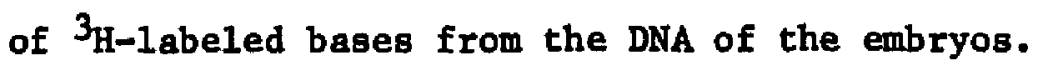

${ }^{32} \mathrm{P}-1$ abelled $\mathrm{CD}$ males were fed ${ }^{3} \mathrm{H}$-methyl methanesulfonate (specific activity $6900 \mathrm{mC} \pm / \mathrm{mM})$ and mated to $\mathrm{Q}$ virgins for one day. After mating the males were separated from the females and frozen. Egg samples were collected from the inseminated females with the use of $\mathrm{CO}_{2}$ and allowed to develop 30 minutes before freezing on dry ice. The Individual embryo samples were pooled to form one large sample of 30 minute eggs. Sperm cells were sampled by removing the seminal vesicles from frozen $3_{\mathrm{H}-\mathrm{MMS}}$ treated males, and pooled to form one vesicle sample. Each of the two samples were placed in a glass homogenizer and ground in a mercaptoethanol solution $\left(6 \mathrm{ml}, 6.7 \%\right.$ in $1 \times \mathrm{SSC} ; 0.1 \mathrm{M} \mathrm{TrIs,} \mathrm{pH} \mathrm{8.5)} \mathrm{at} 4^{\circ} \mathrm{C}$ unt11 homogenized. If there 18 a differential removal of ${ }^{3} \mathrm{H}-1$ abel by the extraction procedure it would most likely occur when the disrupted cells are in the mercaptoethanol prior to the first separation of the nucleic acids from the associated protelns and cellular homogenate. Beyond this point in the extraction procedure the separated nucleic acids from both sources would have similar characteristics and thus their bases would not be subject to differential removal.

The $108 \mathrm{~s}$ of ${ }^{3} \mathrm{H}-1$ abeled bases from either DNA source in the mercaptoethanol solution can be detected by comparing the ${ }^{3} \mathrm{H} /{ }^{32} \mathrm{p}$ ratio of final DNA extracts that are allowed to remain in the mercaptoethanol solution for differing lengths of time. After homogenization in the 
mercaptoethanol solution DNA extraction procedures were carried out on aliquots of solution incubated for 0,1 , and 4 hours. The ${ }^{3} \mathrm{H}$ and ${ }^{32} \mathrm{P}$ dpm and the ${ }^{3} \mathrm{H} /{ }^{32} \mathrm{P}$ ratios for these extracts are given in Table XII. Loss of labeled bases from either the egg or the sperm DNA while in the mercaptoethanol solution would result in a time dependent reduction of ${ }^{3} \mathrm{H}$-label in the final DNA extracts. Since the phosphorus moiety of the DNA should not be affected by $108 \mathrm{~s}$ of the labeled bases the ${ }^{3} \mathrm{H} /{ }^{32} \mathrm{P}$ ratio should decrease if there is a time dependent loss of alkylated bases in the mercaptoethanol solution. The samples from the sperm cell DNA of the vesicles and the sperm derived DNA of the embryos increase in ${ }^{3} \mathrm{H}$ and ${ }^{32} \mathrm{P}$ dmp with increased time in the mercaptoethanol, but maintained the same ${ }^{3} \mathrm{H} /{ }^{32} \mathrm{P}$ ratio. This indicates that the efficiency of the DNA extraction was increased with longer exposures to mercaptoethanol, but there was no decrease in the level of ${ }^{3} \mathrm{H}-1$ abel in any of the DNA extractions. An ANOV of the ${ }^{3} \mathrm{H} /{ }^{32} \mathrm{P}$ ratios of DNA derived from the 0,1 , and 4 hour Incubations of the sperm and embryos (Table X) Indicate that there is no change with increased incubation time in mercaptoethanol. Therefore, the decrease in ${ }^{3} \mathrm{H}-1$ abel observed in the embryo samples of the experiments must be due to something other than a differential effect of the extraction procedure. 
TABLE X. VERIFICATION OF DNA EXTRACTION PROCEDURE AND F-TEST OF RATIOS

\begin{tabular}{|c|c|c|c|c|}
\hline DNA Source & $\begin{array}{l}\text { Time in Mercapto- } \\
\text { ethanol Solution } \\
\text { (hours) }\end{array}$ & $3_{H-D P M}$ & ${ }^{32} \mathrm{P}-\mathrm{DPM}$ & ${ }^{3} \mathrm{t} /{ }^{32} \mathrm{pa}$ \\
\hline \multirow[t]{3}{*}{ Embryos } & 0 & 237 & 31 & $7.61 \pm .02$ \\
\hline & 1 & 315 & 44 & $7.16 \pm .02$ \\
\hline & 4 & 575 & 80 & $7.14 \pm .01$ \\
\hline \multirow[t]{3}{*}{ Sperm Cells } & 0 & 924 & 407 & $2.27 \pm .01$ \\
\hline & 1 & 1515 & 616 & $2.46 \pm .01$ \\
\hline & 4 & 2127 & 866 & $2.45 \pm .01$ \\
\hline
\end{tabular}

a Relative Standard Deviation based on counting time (sampling error). 
TABLE X (Continued)

\begin{tabular}{lccc}
\hline & \multicolumn{3}{c}{ Time in Mercaptoethanol } \\
\cline { 2 - 3 } & $0 \mathrm{hr}$. & $1 \mathrm{hr}$. & $4 \mathrm{hr}$. \\
Emabryos & 7.61 & 7.16 & 7.14 \\
Sperm cells & $2.27 \ldots$ & 2.46 & $2.45 \ldots$ \\
\hline
\end{tabular}

ANOVA TABLE

\begin{tabular}{|c|c|c|c|c|c|}
\hline Source & $\begin{array}{l}\text { Degrees of } \\
\text { Freedom }\end{array}$ & $\begin{array}{l}\text { Sum of } \\
\text { Squares }\end{array}$ & $\begin{array}{l}\text { Mean } \\
\text { Square }\end{array}$ & F-test & Probability \\
\hline Total & 5 & 36.32 & & & \\
\hline Time & 1 & 0.03 & 0.030 & 0.46 & NS \\
\hline Stage & 2 & 36.16 & 18.080 & 278.15 & $\mathrm{P}<.01$ \\
\hline Error & 2 & 0.13 & 0.065 & & \\
\hline
\end{tabular}




\section{DISCUSSION}

The ${ }^{3}$ H-ethyl groups attached to the ${ }^{32} \mathrm{P}$-labeled DNA of the ${ }^{3} \mathrm{H}-\mathrm{EMS}$ treated sperm cells might be affected in several ways following exposure. First, these ethy1 groups might remain attached to the DNA derived from sperm during the entire period studied, a period which began with ${ }^{3}$ H-EMS treatment of the male, continued through insemination, sperm storage in the female's seminal receptacle, fertilization of the egg, and terminated at various stages of embryonic development. The ${ }^{32} \mathrm{P}$ label is randomly incorporated in the DNA of the sperm cells, therefore $108 s$ of the ${ }^{32} \mathrm{P}$ and the chain breaks assoclated with the ${ }^{32} \mathrm{P}$ decay occur at random with respect to the ${ }^{3} \mathrm{H}$-ethyl sites. When the majority of the ethy1 groups remain attached to the DNA throughout embryonic development the ${ }^{3} \mathrm{H} /{ }^{32} \mathrm{P}$ ratio after correction for ${ }^{32} \mathrm{P}$ decay should be constant for all stages sampled (sperm and embryos). No significant difference would be expected between this ratio observed In the DNA of the sperm cells and the ratio in the sperm derived DNA of the embryos.

Another possible occurrence would be the dissociation of the Induced $3_{\mathrm{H}-e t h y 1}$ groups from the ${ }^{32} \mathrm{P}-1$ abeled sperm derived DNA sometime after treatment. This dissociation of ethyl groups might occur in sperm cells while they are stored in elther the males or females and/or It could take place in the embryo during development. The loss of ethyl groups from the alkylated sperm derived DNA might result from several causes. Alkyl purines are hydrolytically removed from DNA at a mean rate approximately $1 \times 10^{5}$ times faster than the rate observed 
for hydrolytic loss of non-alkylated purines from DNA (LIndahl and Nyberg, 1972; Strauss et al., 1975). Lett et al., (1962) have shown that hydrolysis of the quaternized alkyl purine products in double stranded DNA occurs at the N-glycosidic bond which links the sugar from the DNA backbone to the alkylated purine, but does not frequently occur at the bond which links the alkyl group to the purine. Thus, alkyl purines are hydrolytically split from the DNA but the alkyl groups are not readily hydrolyzed from the alkyl purine. Since the mafority of ethylations on DNA occur at the $N-7$ position of guanine (Lawley and Brookes, 1963; Aaron et al., 1973; Sun and Singer, 1975) a

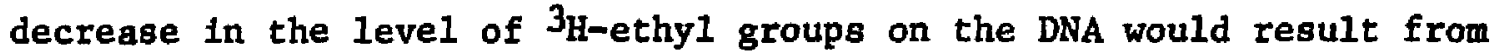
the hydrolytic loss of the ethylated purines. The hydrolytic 1088 of ethylated bases from the alkylated sperm DNA during storage, either in the seminal vestcles of the males or the seminal receptacles of the females, should cause the ${ }^{3 \mathrm{H} /}{ }^{32} \mathrm{P}$ ratio of stored sperm DNA to undergo a time dependent reduction. The magnitude of this reduction would be directly related to the amount of $3 \mathrm{H}$-ethylated bases $108 \mathrm{t}$, and since the majority of alkylattons in the Drosophila DNA occur on the purine sites (Aaron et a1., 1973) the rate of reduction of this ratio should not be significantly different from the estimated depurination rate for alkylated DNA. The hydrolytic loss of ethylated bases druing embryonic development could also result in a time dependent reduction in the embryonic ${ }^{3} \mathrm{H} /{ }^{32} \mathrm{P}$ ratio by approximately the rate of DNA depurination for alkylated bases.

The loss of ethyl groups might also result from an active enzymatic removal of alkylated bases from the DNA (Strauss and Robins, 1976; 
Lawley and Orr, 1970; Margison and O'Connor, 1973). An enzymattc removal of ${ }^{3} \mathrm{H}$-ethyl groups or the ${ }^{3} \mathrm{H}$-ethylated bases from treated sperm derived DNA via some repair system must occur at a rate greater than the spontaneous hydrolysis rate for depurination of alkylated bases if it is to be detected as a different process. The onset of such an enzymatic loss of the ${ }^{3} \mathrm{H}-$ labeled ethyl groups should result in a decrease in the ${ }^{3} \mathrm{H} /{ }^{32} \mathrm{P}$ ratio of the sperm derived DNA, etther during storage or embryonic development, at rates significantly faster than the rate for depurination of alkylated DNA.

It is apparent from examination of the ${ }^{3} \mathrm{H} /{ }^{32} \mathrm{p}$ ratios of sperm cells stored in seminal receptacles of female flles for short and long periods of time that the ratio does not remain constant during storage (Table IV and Figure 4). During these periods of storage (0-7 days) the ratio decreased at approximately the rate expected for the hydrolytic loss of a alkylated purines from DNA. The observed mean rate in the reduction of $\%{ }^{3} \mathrm{H}$ from the DNA of stored sperm (Figure 4) 18 $1.61 \mathrm{x}$ $10^{-4} \mathrm{~min}^{-1}$. This value does not appear to differ from the hydrolytic depurination rate of $1.84 \times 10^{-4} \mathrm{~min}^{-1}$ (Strauss et al., 1975). Because this rate of loss is slow and because insemination of the female and fertilization of the egg occurs one to two days after treatment a large proportion of the alkyl groups accumulated in the treated spermatozoa are retained until fertilization.

If this apparent $10 \mathrm{ss}$ of ${ }^{3} \mathrm{H}$ in stored sperm cells is due to a hydrolytic depurination of ethylated bases; it is most probable that this hydrolysis begins with the onset of base alkylation at the time of male treatment, and would continue until all the alkylated bases are removed. It would, therefore, be expected that the sperm derived DNA of the 
early embryos, exhiblt at least a hydrolytic loss of ethylated bases and a corresponding decrease in the ${ }^{3} / /^{32} \mathrm{P}$ rat 10 .

A within experiment comparison of the ${ }^{3} \mathrm{H} /{ }^{32} \mathrm{P}$ ratios from extracted DNA of sperm cells with the ratio from DNA of embryos shows that the ratio in the embryos is significantly decreased from the ratio in the sperm cells (Table II). This decrease in the lsotopic ratio is observed within the earliest embryo stage sampled and continues to be observed throughout the later embryo stages (Table 1, Table III, and Figure 5). Since the DNA extraction procedure extracts DNA nonpreferentially from the two sources (Table X) and since the alkyl phosphotriesters formed in the DNA are apparently stable products (Bannon and Verly, 1972) the difference between the sperm and the embryos must represent an active removal of the ${ }^{3} \mathrm{H}$ which is attached to the ethyl groups on the ethylated DNA bases. The data avallable does not allow the distinction between 1 ) 108 s of the ${ }^{3}$ H-ethyl group from ethylated bases of the DNA and 2) removal of the entire ethylated base from the DNA. However, based on the observations of other investigators (Bannon and Verly, 1972; Lett et a.1., 1962) the latter condition seems more likely.

The release of the ${ }^{3} \mathrm{H}-1$ abel in the embryos occurs in two phases (Figure 5). Between fertilization of the egg and the first few embryonic mitotic divisions the loss of $3_{\mathrm{H}-1 \text { abel from embryo DNA occurs at }}$ a mean rate approximately 400 times greater than the rate for spontaneous hydrolytic depurination of alkylated DNA. The data in Table 1

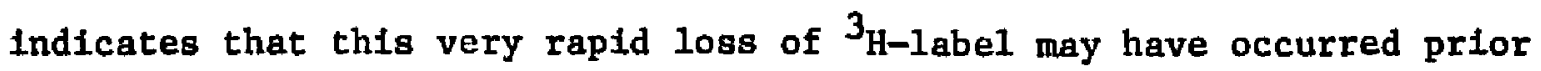
to the earliest embryo stages sampled (eggs collected 15 and 20 minutes 
after deposition) and before the onset of the first mitotic division. The difference between ${ }^{3} \mathrm{H} /{ }^{32} \mathrm{P}$ ratios observed in sperm and the earliest stage measured In the embryo would require a rate of selective loss of ${ }^{3} \mathrm{H}$ versus randomized $10 \mathrm{ss}$ of ${ }^{32} \mathrm{P}$ that $1 \mathrm{~s}$ at least as high as $8.4 \mathrm{x}$ $10^{-2}$ min $^{-1}$ (Table VI). This mintmum estimate for the loss of ${ }^{3} \mathrm{H}$ during the short interval between sperm penetration of the egg and the first embryo sample is significantly faster than could be accounted for by spontaneous hydrolysis of ethylated purines from DNA (Table VI).

The second phase of the ${ }^{3} \mathrm{H}-10 s s$ appears to occur after the first or second mitotic division. During the period from the first mitotic division to gastrula formation the ${ }^{3} \mathrm{H}-1$ abel is lost at about 0.02 times the rate observed in the first phase. The t-test analysis (Table VII) Indicates that the mean rate for this slow phase $\left(1.30 \times 10^{-3} \mathrm{~min}^{-1}\right)$ based on 8 ix observations is not significantly different from the rate of hydrolysis for alkylated purines. The slow phase rate was computed using the 15 minute embryo samples as the initial point in the regression. However, due to selective loss of over half of the initial alkylations, the 15 minute embryo samples may have a distribution of alky1 sites quite different from the inltial distribution of alkyl sites in the sperm DNA. Thus, this slow phase rate may be biased downward because of a higher proportion of stable alkylation sites. EMS induction of mutations after treatment of Drosophila males is stage specific. The highest mutation frequencies occur when germ cells are treated as late spermatids or mature spermatozoa (Fahmy and Fahmy, 1957 and 1951; Alderson, 1965; Epler, 1966; Jenkins, 1967a and 1967b). Treatment of these stages results in the accumulation of high levels 
of alkylation on the sperm DNA but produce comparatively low frequencles of sex-1inked recessive mutations in the progeny of treated males (Aaron and Lee, 1977). A high frequency of the EMS Induced mutations are mosalc mutations (Jenkins, 1967a and 1967b; Epler, 1966; Alderson, 1967; Lee et al., 1970). Analysis of the distribution of mosalcs from several experimental sources has led Lee (1976) to estimate that on the average mosalc embryos carry a mutation in only $1 / 4$ of their nuclei. Finally, there is an apparent direct relationship between the time treated sperm cells are stored in the seminal receptacles and the frequency of translocations, chromosome loss and dominant lethals observed in the progeny (Abrahamson et a1., 1969; Srám, 1970a and 1970b; Schalet, 1977).

There is evidence from several sources for the existance of cellular enzymes which can recognize and remove alkylated DNA bases (Strauss and Robins, 1967; KIrt1kar and Goldthwatt, 1974; Lawley and Orr, 1970; Margison and $0^{\prime}$ Connor, 1973). In addition it has been shown that alkylated bases are hydrolyzed off alkylated DNA at rates significantly greater than those for hydrolytic loss of the corresponding nonalkylated bases (LIndahl and Nyberg, 1972; Lawley and Brookes, 1963; Margison and $0^{\prime}$ Connor, 1973; Strauss et al., 1975). Enzymatic removal and hydrolytic removal both leave apurinic and possibly apyrimidinic sites in DNA at the point of base removal. These apurinic and apyrimidinic DNA sites are unstable and could be further hydrolyzed to form single-strand breaks in the DNA (Strauss and H111, 1970; Ross, 1958). Endonucleases specific for apurinic (apyrimidinic) sites have been Isolated from cellular extracts of bacteria, higher plants and mamals (Verly and Rassart, 1965; Verly et al., 1973; Lindahl and Andersson, 
1972; Lfungquist and LIndah1, 1974; Verly and Paquette, 1973). These endonucleases recognize apurinic sites, hydrolyze phosphodiester bonds near each apurinic site and thus introduce single strand breaks into the DNA. Verly et al., (1974) suggests that these endonucleases are part of an enzymatic system whlch repairs the naturally occurring In vivo depurination of cellular DNA. The exact nature of this enzymatic system is not known, but there is in vitro evidence to suggest that excision repair processes do repatr alkylation damage in DNA (Ver1y et al., 1974). Boyd and Presley (1974) have observed that EMS Induces In vivo unscheduled DNA replication in mitotic cells of Drosophila larvae. Unscheduled DNA synthesis would be expected to result when a cellular excision-repair system operates to repair damaged DNA. Boyd and Setlow (1975) and Boyd et al. (1975) also provide evidence that certaln MMS sensitive strains of Drosophila melanogaster are deficlent for normal excision-and post-replication repair processes. Both of these processes would be enzyme mediated.

The following sequence of events is proposed to account for the various aspects of the EMS mutation spectrum In Drosoph1la and the apparent shift in the ${ }^{3} \mathrm{H} /{ }^{32} \mathrm{P}$ ratio observed between sperm DNA and sperm derived DNA of embryos. The sequence is based on the assumption that among the "normal complement" of Drosophila cellular. enzymes there exists a system that has the capability of recognizing, removing and repairing DNA damage regulting from alkylation of the nitrogenous DNA bases. 1) During spermatogenesis the early cell stages (spermatogonia to early spermatids) are capable of enzymatically repairing DNA alkylation damage induced by EMS treatment of the males. As a result the level of promutagentc and/or mutagentc effects which could 
accumulate are kept to a minimum. 2) Upon undergoing the metabolic, physiologic and morphologic changes which transform spermatids to spermatozoa; spermatids lose the ability to rapidly enzymatically repair DNA alkylation damage. Late spermatids and mature spermatozoa are, therefore, Incapable of carrying out this repair. It had earlier been shown that the ablitty to rejoln chromosomes broken by Ionizing radiation was lost in late spermat1ds and spermatozoa. As a result of losing this repair ability alkylations accumulate to relatively high levels on the DNA in these cell stages. During these stages hydrolytic loss of alkylated bases could occur. Since the mafority of the alkylations are expected to occur on purine bases (Aaron et al., 1973; Lawley and Brookes, 1963; Sun and Singer, 1975) the rate of 1088 of alkylated bases would be expected to approximate the rate predicted for hydrolytic 1088 of alkyl purines $\left(1.84 \times 10^{-4} \mathrm{~min}^{-1}\right)$, and would account for the decrease in the ${ }^{3} \mathrm{H} /{ }^{32} \mathrm{P}$ ratios observed durting sperm storage. Hydrolytic depurination of the alkyl purines from the sperm DNA would lead to a time dependent accumulation of apurinic sites. These ungtable sites might be further hydrolyzed to single-strand DNA breaks in the sperm or be retained as apurinic sites until fertilization. 3) The ovum contains finfte levels of enzymes required for repairing alkylation DNA damage, and therefore after fertllization the accumulated alkylated bases and alkylation Induced damage (apur Inic sites and single-strand breaks) introduced on the sperm derived DNA are subject to rapid repair. It is also possible that the mature spermatozoa contains repair enzymes, which are unable to function in the sperm but can function in the environment of the newly fertilized egg because the substrate (alkylated DNA) becomes receptive to the 
enzymes.

The Effect of Enzyme Repair on Recessive Mutation Induction

The mutation response observed in Drosoph1la for the EMS Induction of sex-1Inked recessive lethals can be accounted for 1f there are two different repair mechanisms available to repair alkylation damage. The first system is an error-free repair system which removes induced alkylations in the DNA of the spermatogonia and the early stages of spermatogenesis (spermatocytes to early spermatids). This repalr system would reduce the initlal level of alkylation and the mutagenic potential of alkylation at these stages such that the Induced frequency of mutations is not significantly increased from the control rate. The second system is an error-prone repalr system which removes alkylation damage in the sperm pronucleus prior to the first cleavage division in the embryo. This mechanism would have a low finite probability (b) of producing a mutagenic alteration each time it repairs a site of alkylation damage. The frequency of induced mutations (e.g. sex-linked recessive lethal mutations) would therefore be linearly related to the level of alkylation such that;

$$
m=b X=\text { the mutation frequency induced, }
$$

where; $\quad b=$ probability of repair inducing a mutation

and; $\quad X=1$ level of alkylation (alkylation per nucleotide). These two repair systems, an error-free system operating primarily in the early stages of spermatogenesis and an error-prone system operating prior to the first cleavage division in the embryo, could account for the germ stage spectficity for Inducing recessive mutations (Fahmy and Fahmy, 1957 and 1961; Alderson, 1965; Epler, 1966; JenkIns, 1967a and 
1967b), the germ stage speciflcity for induced DNA alkylation (Aaron et al., 1973), and the apparent inefficlency with which DNA alkylation in spermatozoa are converted to mutations (Aaron and Lee, 1978). Most Important1y, the relationshlp between alkylation and genetic response predicted by the sequential operation of the two repair systems is consistent with the Iinear dose-response relationship observed by Aaron and Lee, (1978).

Effect of Accumulation of Apurinic sites on Mutation Induction

A time dependent accumulation of alkylation damage on sperm DNA could result in the increasing frequency of chromosome aberrations observed with storage of treated sperm cells (Abrahamson et al., 1969; Srám, 1970a and 1970b; Schalet, 1977). After EMS treatment the accumulation of apurinic sites in the DNA as a result of hydrolysis of alkylated bases is time dependent. Therefore, stored sperm DNA should contain more apurinic sites than DNA from non-stored sperm. Increasing the level of apurinic sites should also increase the probability of Introducing hydrolytically induced single-strand breaks in the treated DNA of stored sperm (Strauss and Hill, 1970). A1so, the efficlency of the repalr for apurinic sites in the embryos would depend on the concentration of the repair enzymes and the concentration of the apurinic sites in the alkylated DNA. Therefore, it is possible that as a result of storage, apurintc sttes in the alkylated DNA could accumulate to such high levels that during the early embryo perfod the repair system could not complete repair on all the apurfnic sites present in the alkylated sperm derived DNA. The activity of an endonuclease specific for apurinic sites without subsequent or concurrent repair activity 
could Introduce single-strand breaks Into the alkylated sperm derived DNA. Alternately, apurinic sites which are retained throughout the repair pertod in the embryo could be hydrolyzed at a later time to introduce single-strand breaks Into the alkylated DNA. During the first round of DNA synthesis in the embryo any remaining single-strand breaks could be converted to chromatid breaks. Subsequently, these chromatid breaks can be converted to the types of chromosome aberrations observed in progeny of stored treated sperm cells. Thus, increasing the time of sperm storage could result in an increased potential for chromosome aberrations In the genome of the progeny.

The Effect of Alkylation on the Nuclear Complement of the Embryo

Fertilization in Drosophila is a gonomeric process in which both the haploid sperm cell and the haplold fertilization nucleus of the egg undergo a mitotic division prior to fusion (Heuttner, 1924; Sonnenblick, 1965). The egg and sperm pronuclet are aligned side by side on the metaphase plate but remain separate until Immedlately following anaphase of this first mitotic division. At this time the products of mitosis fuse yielding two diploid embryonic nuclel each containing a material and paternal genetic complement. The first DNA synthesis in the embryo probably occurs prior to the fusion of the daughter pro-nuclei. Individual EMS alkylations occur on only one of the two strands of a DNA molecule. If the original single-strand DNA alkylation damage is converted to a double-strand chromosome alteration prior to the first DNA synthesis both daughter sperm pronuclef will carry the alteration. Depending on the nature of the alteration the resulting embryo may carry a mutation in all of its nuclel or be mosalc for the mutation. When 
the chromosome alteration is a mutagenic alteration, the resulting embryo would carry the mutation in all its nuclef. Alternately, if the doublestrand chromosome alteration is a promutagentc alteration (an alteration which has the potential of producing a mutagenlc alteration at a later time) the embryo, if mutant, would be mosaic for the mutation. Since the majority of the EMS Induced mutations are mosalc, conversion of single-strand alkylation damage to a double-strand mutagenic alteration prior to the first DNA synthesis probably occurs infrequently. Unrepaired or mis-repaired single-strand alkylation damage on the sperm derived DNA retained through the first DNA synthesis would induce a mutagenic or promutagentc event in only one of the two daughter sperm pronucle1. The other sperm pronucleus would contain no alteration at the corresponding DNA site. Thus, after fusion of the Egg and sperm pronuclei only one of the two diplold embryo nuclei would carry a mutagenic or promutagenic alteration at an original alkylated site. Retention of single-strand alkylation damage through the first DNA synthesls or mis-repair of alkylation damage, can produce mosaic embryos. Single-strand chromatid breaks retained after the first DNA synthesis can result in embryos which are mosaic for chromosome aberrations, but because of the small number of nuclel which give rise to the germ line (Sonnenblick, 1965) and because of the poor mixing of embryonic nuclet from which the germ line nuclel are drawn resulting in the effective number of mutant nuclel being 1.3 (Lee, et al., 1970; Lee, 1976), most mosaic Individuals will be scored as complete (Individuals that contain a completely mutant or non-mutant germ line) when judged by mutation transmisston. Retention of single-strand alkylation damage and/or misrepair can also produce a complete mutant embryo. This can occur if 
one of the two embryonic nuclel formed after pronuclel fusion contains a single-strand break or another mutagenfc alteration, while the other nucleus contains a dicentric bridge or any other configuration which causes early lethallty (Lelgh, 1976). If the mutagenlc alteration in the one embryonic nucleus is vlable the embryo will develop and all Its nuclei w111 carry the mutagenic alteration from the original viable embryonic nucleus.

The frequency of mutant carrylng nuclel in a mosaic embryo is dependent on the time during embryonic development at which alkylation damage 18 converted to a mutation. When the mutation is fixed after the first DNA synthesis $50 \%$ of the nuclel should carry the mutation, while mutations that are fixed after the second round of DNA synthesis would be carried by only $25 \%$ of the embryonic nuclei, etc. On the average only $1 / 4$ of the nucled of mosalc embryos carry recessive mutatIons (Lee, 1976). This indicates that the majority of recessive mutations may not be fixed until the second or later rounds of DNA synthesis in the embryo. 


\section{CONCLUSIONS}

1. Storage of ${ }^{3} \mathrm{H}$-EMS treated Drosophrla melanogaster sperm cells in the seminal receptacles of inseminated females results in a time dependent decrease in the level of Induced ${ }^{3} \mathrm{H}$-ethyl groups on the sperm DNA.

2. The rate of decrease in the ${ }^{3} \mathrm{H}$-labeled alkyl groups is slow and does not appear to be greater than the rate predicted for hydrolytic $108 s$ of alkyl purines $\left(1.84 \times 10^{-4} \mathrm{~min}^{-1}\right)$ from DNA.

3. Between the time of fertilization and the first or second cleavage divisions in the embryo (21-33 minutes after fertilization) the level of alky1 groups on the sperm derived DNA is reduced by a rate approximately 400 times greater than that expected for hydrolytic loss of alkyl purines.

4. Beyond this stage of embryonic development the level of alkyl groups continues to decrease, but the rate of $108 s$ is not significantly different from that expected for the hydrolytic depurination of alkylated DNA.

5. Even though alkyl groups are lost during the earlier and later stages

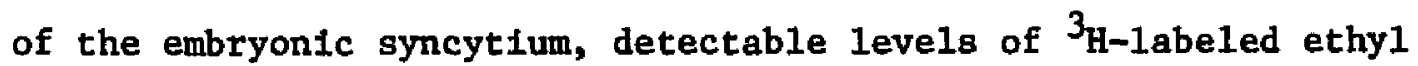
groups are still observed when the embryo undergoes cellularity at the gastrula stage (180 minutes after fertilization). 


\section{LITERATURE CITATION}

Aaron, C.S., and Lee, W. R., (1975) Computerized 11quid scintillation counting data management, 1 . Time sequence for decay correction: A key for data storage and retrleval, Analytical Blochem. 65: 573-577.

Aaron, C.S., and Lee, W.R., (1977) Molecular dosimetry of the mutagen ethyl methanesulfonate in Drosophila melanogaster spermatozoa: Linear relation of DNA alkylation per sperm cell (dose) to sexlinked recessive lethals, (Abstract) Proceedings of the 8th Annual Meeting of the Environmental Mutagen Society in Colorado Springs, Co.

Aaron, C.S., and Lee, W.R., (1978) Molecular dosimetry of the mutagen ethy1 methanesulfonate in Drosophtla melanogaster spermatozoa: Linear relation of DNA alkylation per sperm cell (dose) to sexlinked recessive lethals, Mutation Res. 49:27-44.

Aaron, C.S., Lee, W.R., Janca, F.C., and Seamster, P.M., (1973) Ethylation of DNA in the germ Iine of male Drosophila melanogaster, (Abstract) Proceedings of the 13th Intemational Congress of Genetics, Berkeley, Californta, Genetics $74: 1 s$.

Aaron, C.S., Nardin, H.E., and Lee, W.R., (1977a) Glass filter gupports for treatment of adult $D$. melanogaster with chemical mutagens, Drosophila Information Service 52:166.

Aaron, C.S., Lee, W.R., Seamster, P.M., and Janca, F.C., (1977) A nonaqueous gas exposure technique for microliter quantities of chemical mutagens, Drosophila Informat Ion Service 52:174.

Abrahamson, S., Kirlazis, W.C., and Sabol, E.M., (1969) A storage effect of ethy1 methanesulfonate (EMS) on the induction of translocations in Drosophila sperm, Drosophila Information Service 44:110-111.

Alderson, T., (1965) Chemically induced delayed germinal mutation in Drosophila, Nature $207: 164-166$.

Amano, E., and Smith, H.H., (1965) Mutations Induced by ethyl methanesulfonate in Maize, Mutation Res. 2:344-351.

Auerbach, C., (1946) Chemically Induced mosaicism in Drosophila melanogaster, Proc. R. Soc. Edinb. B62:211-221.

Ayad, S.R., Fox, M., and Fox, B.W., (1969) Non-semiconservatIve incorporation of labeled 5-bromo-2'-deoxyuridine in lymphoma cells treated with low doses of methyl methanesulfonate, Mutation Res. 8:639-645. 
Bannon, P., and Verly, W., (1972) Alkylation of phosphates and stability of phosphate triesters in DNA; Eur. J. Blochem. 31:103-111.

Bender, M.A., Grigge, H.G., and Bedford, J.S., (1974) Mechanisms of chromosomal aberration production, III. Chemicals and Ionizing radiation, Mutation Res. 23:197-212.

Bhatia, C.R., (1967) Increased mutagenlc effect of ethyl methanesulfonate when dissolved in dimethyl sulfoxide, Mutation Res. 4:375-376.

Boyd, J.B., Golino, M.D., and Setlow, R.B., (1976b) The me1-9a mutant of Drosoph1la melanogaster increases mutagen sensitivity and decreases excision repair, Genetics 84:527-544.

Boyd, J.B., and Presley, J.M., (1974) Repalr replication and photorepair of DNA in larvae of Drosophila melanogaster, Genetics 77: 687-700.

Boyd, J.B., and Setlow, R.B., (1976a) Characterization of postreplication repalr in mutagen-sensitive strains of Drosophila melanogaster, Genetics 84:507-526.

Brink, N.G., (1968) Proteln synthesis.during spermatogenesis in Drosophila melanogaster; Mutation Res. 5:192-194.

Brookes, P., and Lawley, P.D., (1963) Effects of alkylating agents on T2 and T4 bacterlophages, B1ochem. J. $89: 138-144$.

Buhl, S.N., and Regan, J.D., (1973) DNA replication in human cells treated w1th methyl methanesulfonate, Mutation Res. 18:191-197.

Cattanach, B.M., Pollard, C.E., and Isaacson, J.H., (1968) Ethyl methanesulfonate induced chromosome breakage in the mouse, Mutation Res. 6:297-307.

Chu, E.H.Y., and Malling, H.V., (1968) Mammalian cell genetics, II. Chemical Induction of specific locus mutations in Chinese hamster cells in vitro, Proc. Nat. Acad. Sci. U..‥ 61:1306-1312.

Cooper, K.W., (1965) Normal spermatogenesis in Drosophila, in: Blology of Drosophila, (M. Demerec, ed.) Hafner Publishing Co., New York,

Das, C.C., Kaufmann, B.P., and Gay, H., (1964a) Histone-protein transition in Drosophtla melanogaster, I. Changes durting spermatogenests, Exp. Ce11 Res. 35:507-514.

Das, C.C., Kaufmann, B.P., and Gay, H., (1964b) Autoradiographic ev1dence of synthesis of an arginine-rich histone during spermiogenesis in Drosophila melanogaster, Nature 204:1008-1009. 
Drake, J.W., (1970) The Molecular Basis of Mutation, Holden-Day, San Francisco.

Ehling, U.H., Cummings, R.B., and Malling, H.V., Induct Ion of dominant lethal mutations by alkylating agents in male mice, Mutation Res. 5:417-428.

Epler, J.L., (1966) Ethyl methanesulfonate-Induced lethals in Drosophila, Frequency-dose relations and multiple mosaicism, Genet1c8 54:31-36.

Fahmy, O.G., and Fahmy, M.J., (1957) Mutagenic responses to alky1 methanesulfonate during spermatogenesis in Drosophila melanogaster, Nature 180:31-34.

Fahmy, O.G., and Fahmy, M.J., (1961) Cytogenetic analysis of the action of carcinogens and tumor Inhibitors in Drosophila melanogaster, IX. The cell gtage response of the male germ line to the mesyloxy esters, Genet1cs 46:361-372.

Ficsor, G., (1965) The nature and expression of ethyl methanesulfonate (EMS), diethyl sulfate (DES), X-rays, and UV-induced mutations in Zea mays, Proceedings of the Symposium on the Mutational Process, Prague August 9-11:163-168.

Fishbein, L., Flamn, W.G., and Falk, H.L., (1970) Chemical Mutagens, Environmental Effects on Blological Systems, Academic Press, New York.

Freese, E., (1963) Molecular mechanisms of mutations, in: Molecular Genet1cs (J.H. Taylor, ed.), Part 1, Academic Press, New York, 207-269.

Generoso, W.M., and Russe11, W.L., (1969) Strain and sex varlations in the sensitivity of mice to dominant-lethal induction with ethyl methanesulfonate, Mutation Reg. 8:589-598.

Generoso, W.M., Russe11, W.L., Huff, S.W., Stout, S.K., and Gosslee, D.G., (1974) Effects of Dose on the Induction of Dominant-Lethal Mutations and Heritable Translocations with Ethyl Methanesulfonate in Male Mice, Genet1cs 77:741-752.

Gerchman, L.L., and Ludlum, D.B., (1973) The properties of $0^{6}$ methy1guanine in templates for RNA polymerase, Biochim. Biophys. Acta. $308: 310-316$.

Grossman, L., (1975) Exclston repair of DNA, In: DNA gynthesis and Its Regulation, (M. Goullan and P.C. Hanawalt, eds.; C.F. Fox, series ed.), W.A. Benjamin Inc., Menlo Park, 791-814.

Higgins, N.P., Kato, K., and Strauss, B.. (1976) A model for replication repair in mammalian cells, J. Mol. Biol. 101:417-425. 
H1ldreth, P.E., and Lucches1, J.C., (1963) Fert111zation In Drosoph1la: 1. Evidence for the regular occurrence of monospermy, Developmental Blology $6: 262: 278$.

Huettner, A.G., (1924) Maturation and fert1lization in Drosoph1la melanogaster, J. Morph. Phys1ol. 39:249-265.

Jenkins, J.B., (1967a). The Induction of mosalc and complete dumpy mutants In Drosophila melanogaster with ethyl methanesulfonate; Mutation Res. 4:90-92.

Jenkins, J.B., (1967b) Mutagenesis at a complex locus In Drosophila with the monofunctional agent ethyl methanesulfonate, Genetica $57: 783-793$.

Krieg, D.R., (1963) Ethy1 methanesulfonate-Induced reversion of bactertophage T4rII mutants, Genetics 48:561-580.

Kirtikar, D.M., and Goldthwait, D.A., (1974) The enzymatic release of 0-6-methylguanine and 3-methyladenine for DNA reacted with the carclnogen N-methyl-N-nItrosourea, Proc. Nat. Acad. Sc1. U.S. 71:2022-2026.

Laird, C.D., (1973) DNA of Drosophila chromosomes, Annual Review of Genet1cs $7: 177-204$.

Lawley, P.D., (1966) Effects of some chemical mutagens and carcinogens on nucleic acids, in: Progress in Nucleic Acld Research and Molecular Biology (J.N. Davidson and W.E. Cohn, eds.), Academic Press, New York, 5:89-131.

Lawley, P.D., (1974a) Some chemical aspects of dose-response relationships in alkylation mutagenesis, Mutation Res. 23:283-295.

Lawley, P.D., (1974b) Alkylation of nucleic acids and mutagenesis, in: Molecular and Environmental Aspects of Mutagenesis (L. Prakash, F. Sherman, M. W. Miller, E.W. Lawrence, and H.W. Taber, eds.), Proceedings of the Sixth Rochester International Conference on Environmental Toxicity, Charles C. Thomas, Publisher, Springfield, 17-33.

Lawley, P.D., (1975) "Exclsion" of bases from DNA methylated by carcinogens in vivo and its possible significance In mutagenesis and carcfnogenesis, in: Molecular Mechanisms for Repair of DNA (P.C. Hanawalt and R.B. Setlow, eds.; A. Holleander, series ed.), Part A, Plenum Press, New York, 25-28.

Lawley, P.D., and Brookes, P., (1961) Actdic dissociation of 7:9dialkylguanines and its possible relation to mutagentc properties of alkylating agents, Nature 192:1080-1082.

Lawley, P.D., and Brookes, P., (1963) Further studies on the alkylation of nucleic acids and their constituent nucleotides, Biochem. J. 89: 127-138. 
Lawley, P.D., and Orr, D.J., (1970) Specific excloton of methylation products from DNA of Escherichla col1 treated with N-methyl-N'nitro-N-n1trosoguanidine, Chem. -Biol. Interactions 2:154-157.

Lawley, P.D., and Thatcher, C.J., (1970) Methylation of deoxyribonucleic actd in cultured mammalian cells by $N$-methyl-N'-nitro-N-nitrosoguanidine: The influence of cellular thiol concentrations on the. extent of methylation and..the 6-oxygen atom of guanine as a stte of methylation, B1ochem: J. 116:693-707.

Lee, W.R., (1975) Comparison of the mutagenic effects of chemicals and Ionizing radiation using Drosophila melanogaster test systems, In: Radlation Research; Blomedical, Chemical and Physical Perspectives (0.F. Nygaard, H.I. Adler and W.K. Sinclair, eds.), Academic Press, New York, 976-983.

Lee, W.R. (1976) Chemfcal mutagenesis, In: The Genetics and Blology of Drosophila (M. Ashburner and E. Novitski, eds.), Academic Press, New York, 1299-1341.

Lee, W.R., Sega, G.A., and Benson, E.S., (1972) Transmutation of carbon14 within DNA of Drosophila melanogaster spermatozoa, Mutation Res. $16: 195-201$.

Lee, W.R., Sega, G.A., and Bishop, J.B., (1970) Chemfcally Induced mutations observed as mosalcs in Drosoph1la melanogaster, Mutation Res. 9:323-336.

Lelgh, B., (1976) Ring Chromosomes and Radiation Induced Chromosome Loss, in: The Genetics and Blology of Drosophila (M. Ashburner and E. Novitski, eds,) Volume 1b, Academic Press, New York, N.Y., 505-528.

Lewls, E.B., and Bacher, F., (1968) Method of feeding ethy1 methanesulfonate (EMS) to Drosophila males, Drosophila Information Service $43: 193$.

Lindah1, T., and Andersson, A., (1972) Rate of chain breakage at apurinfic sites in double-stranded deoxyribonucletc actd, Blochem. $11: 3618-3623$.

Lindah1, T., and Nyberg, B., (1972) Rate of depurination of native deoxyribonucletc acid, Blochem. 11:3610-3618.

LIndsley, D.L., and Grell, E.H., (1972) Genetlc Varlations of Drosophila molanogaster, Carnegle Institution of Washington Publication No. 627.

Ljungquist, S., and Lindahl, T., (1974) A mamalian endonuclease spectflc for apurinic sites in double-stranded deoxyribonucleic actd, 1 . Purification and general properties, J. Biol. Chem. 249:1530-1535. 
Lett, J.T., Parkins, G.M., and Alexander, P., (1962) Physicochemical changes produced in DNA after alkylation, Archives of B1ochemiatry and Blophysics $97: 80-93$.

Loveless, A., (1966) Genetic and Allied Effects of Alkylating Agents, The Pennsylvania State Untversity Press, University Park.

Loveless, A., (1969) Posstble relevance of 0-6 alkylation of deoxyguanosine to mutagenicity and carcinogenficity of nitrosamines and nitrosamides, Nature, 223:206-207.

Loveless, A., and Howarth, S., (1959) Mutation of bacterla at high levels of survival by ethyl methanesulfonate, Nature 184:17801782 .

Ludlum, B., (1970) The properties of 7-methylguanine-containing templates for ribonuclelc acld polymerase, J. Blol. Chem. 245:447-482.

Malling, H.V., and de Serres, F.J., (1968) Identification of genetic alterations induced by ethyl methanesulfonate in Neurospora crassa, Mutation Res. 6:181-193.

Margison, G.P., and O'Connor, P.J., (1973) Blological Implications of the instability of the N-glycosidic bond of 3-methyldeoxyadenosine In DNA, Blochim. Biophys. Acta. 331:349-356.

Miller, A., (1965) The Internal anatomy and histology of the Imago of Drosophila melanogaster, in: Blology of Drosophtla (M. Demerec, ed.) Hafner Publishing Co., New York, N.Y., 518-530.

0livier1, G., and 0livieri, A., (1965) Autoradiographic study of nucleic acld synthesis during spermatogenesis in Drosophila melanogaster. Mutation Res. $2: 366-380$.

Oster, I.I., and Balaban, G., (1963) A modifled method for preparing somatic chromosomes, Drosophila Information Service 37:142-143.

Osterman-Golkar, S., Ehrenberg, I., and Wachtmelster, C.A., (1970) Reaction kinetics and biological action in barley of monofunctional methanesulfonic esters, Radiation Botany 10:303-327.

Rabinowitz, M., (1941) Studies on the cytology and early embryology of the egg of Drosophila melanogaster, J. Morphol. 69:1-49.

Rao, R.N., and Natarajan, A.T., (1965) Mutagenicity of some alkyl alkanesulfonates in barley, Mutation Res. 2:132-148.

Regan, J.D., and Setlow, R.B., (1973) Repair of chemical damage to human DNA, in: Chemical Mutagens; Princlples and Methods for Their Detection (A. Holleander, ed.) Plenum Press, New York, 3:151-169.

Roberts, J.J., Crathorn, A.R., and Brent, T.P., (1968) Repalr of alkylated DNA in mammalian cells, Nature 218:970-972. 
Roberts, J.J., Pascoe, J.M., Smlth, B.A., and Crathorn, A.R., (1971) Quantitative aspects of the repair of alkylated DNA in cultured mammalian cells, II. Non-gemiconservative DNA synthesis ('Repair Synthesis") In Hela and Chinese hamster cells following treatment with alkylating agents, Chem. Biol. Interactions 3:49-68.

Ross, W.C.J., (1958) In vitro reactions of biological alkylating agents, Ann. N.Y. Acad. Sc1. 68:669-681.

Schalet, A., (1977) Further evidence of EMS-Induced rearrangements and a storage effect in Drosophila melanogaster, (Abstract) Genetics $86: 855$.

Scudiero, D., Henderson, E., Norin, A., and Strauss, B., (1975) The measurement of chemically-induced DNA repair synthesis in human cells by BND-cellulose chromatography, Mutation Res. 29:473-488.

Sega, G.A., (1974) Unscheduled DNA synthesis in the germ cells of male mice exposed in vivo to the chemical mutagen ethyl methanesulfonate, Proc. Nat. Acad. Sci. U.S. 71:4955-4959.

Sega, G.A., (1976) Molecular dosimetry of chemlcal mutagens-measurement of molecular dose and DNA repair in mammalian germ cells, Mutation Res. $38: 317-326$.

Shooter, K.V., Edwards, P.A., and Lawley, P.D., (1971) Action of Monoand difunctional sulphur mustards on the RNA-containing bacterlophage $\mu 2$, Blochem. J. $125: 829-840$.

Shooter, K.V., Howse, R., and Merrifield, R.K., (1974b) The reaction of alkylating agents with bacteriophage RI7: Blological effects of phosphotrlester formation, Biochem. J. 137:313-317.

Shooter, K.V., Howse, R., Shar, S.A., and Lawley, P.D., (1974a) The molecular basis for blological inactivation of nuclelc actds: The action of methylating agents on the ribonucleic acid-containing bacterlophage R17, B1ochem. J. 137:303-312.

Singer, B., (1976) All oxygens in nucleic acids react with carcinogenic ethylating agents, Nature 264:333-339.

Sram, R.J., (1970a) The effect of storage on the frequency of dominant lethals in Drosophila melanogaster, Molec. Gen. Genetics 106: 286-288.

Srám, R.J., (1970b) Tize effect of storage on the frequency of translocations in Drosophila melanogaster, Mutation Reg. 9:243-244.

Sonnenblick, B.P., (1965) The early embryology of Drosophlla melano gaster, In: Blology of Drosophtla (M. Demerec, ed.) Hafner PubIIshing Co., New York, 62-167. 
Strauss, B.S., (1961) Specificfty of mutagentc action of the alkylating agents, Nature 191:730-731.

Strauss, B.S., and H111, T., (1970) The Intermedlate in the degradation of DNA alkylated with a monofunctional alkylating agent, Blochim. Blophys. Acta. 213:14-25.

Strauss, B.S., and Robbins, M., (1968) DNA methylated In vitro by a monofunctional alkylating agent as a substrate.for a specific nuclease from Micrococcus lysodelkticus, Blochim. Blophys. Acta. $161: 68-75$.

Strauss, B., Scudiero, D., and Henderson, E., (1975) The nature of the alkylation lesons in mammalian cells, in: Molecular Mechantsms for Repair of DNA (P.C. Hanawalt and R.B. Setlow, eds.; A. Hollaender, series ed.), Part A., Plenum Press, New York, 13-24.

Sun, L., and Singer, B., (1975) The spectflcity of different classes of ethylating agents toward various sites of Hela cell DNA in vitro and in vivo, Blochem. 14:1795-1802.

Tessman, I., Poddar, R.K., and Kunar, S., (1964) Identiflcation of altered bases in mutated single-stranded DNA, I. In vitro mutagenesis by hydroxylamine, ethyl methanesulfonate and nitrous acid, J. Mol. Biol. 9:352-363.

Verly, W.G., (1974) Monofunctional alkylating agents and apurinic sites in DNA, B1ochem. Pharmacol. 23:3-8.

Verly, W.G., (1975) Maintenance of DNA and repair of apurinic sites, In: Molecular Mechantsms for the Repalr of DNA (P.C. Hanawalt and R.B. Setlow, eds.; A. Hollaender, series ed.), Part A, Plenum Press, New York, 39-46.

Verly, W.G., Gossard, F., and Crine, P., (1974) In vitro repalr of apurinic sites in DNA, Proc. Nat. Acad. Sc1. U.S. 71:2273-2275.

Verly, W.G., and Paquette, Y., (1973) An endonuclease for depurlnated DNA In rat liver, Can. J. Blochem. 51:1003-1009.

Verly, W.G., Paquette, Y., and Thibodeau, L., (1973) Nuclease for DNA apurinic sites may be involved in the maintenance of DNA in normal cells, Nature New Blology 244:67-69.

Verly, W.G., and Rassart, E., (1975) Puriftcation of Escherichia coll endonuclease specific for apurinic sites in DNA, J. Biol. Chem. $250: 8214-8219$.

Witkin, E.M., (1975) Relationships among repalr, mutagenesis and survival; Overview, in: Molecular Mechanisms for Repair of DNA (P.C. Hanawalt and R.B. Setlow, eds.; A. Hollaender, series ed.), Part A, Plenum Press, New York, 347-353. 
Würgler, F.E., Ulrłch, H., and Spring, H.W., (1968) An improved method of collecting large numbers of inseminated eggs of Drogophila melanogaster, Separatum Experimentia 24:1082-1083.

Yanofsky, C., Ito, J., and Horn,..V., (1966). Amino acld replacement and the genetic code, Cold Spring Harbor Symp. Quant. Biol. 31:151-162. 
APPENDIXES 


\section{APPENDIX I}

TOTAL COUNTS, COUNTING TIME, \% SPILLOVER, \% EFFICIENCY FOR EXPERIMENTS ONE THROUGH SEVEN ${ }^{a}$

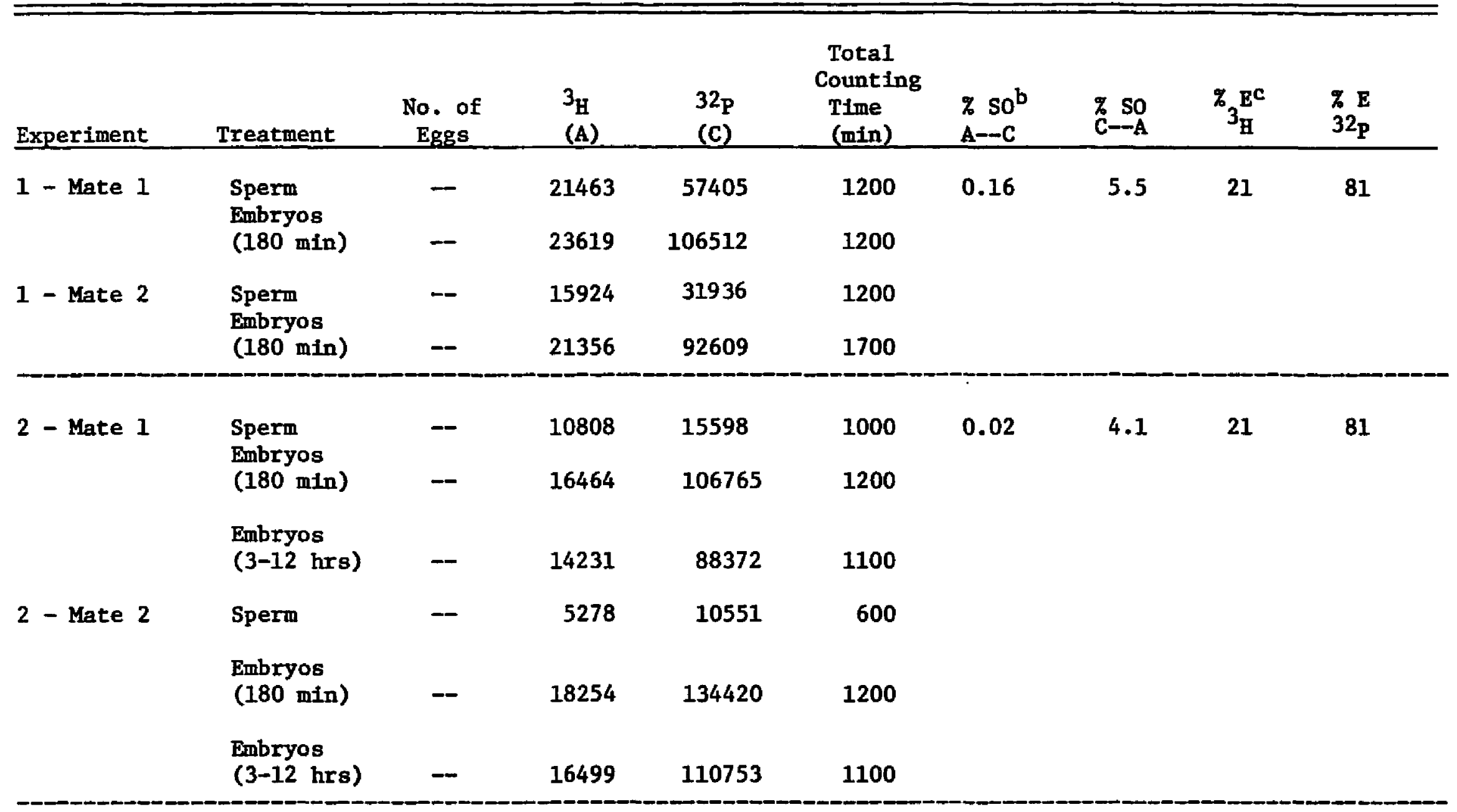


APPENDIX I (Continued)

\begin{tabular}{|c|c|c|c|c|c|c|c|c|c|}
\hline Experiment & Treatment & $\begin{array}{l}\text { No. of } \\
\text { Eggs }\end{array}$ & $\begin{array}{l}{ }^{3} \mathrm{H} \\
\text { (A) }\end{array}$ & $\begin{array}{l}32 \mathrm{P} \\
\text { (c) }\end{array}$ & $\begin{array}{l}\text { Total } \\
\text { Counting } \\
\text { Time } \\
\text { (min) }\end{array}$ & $\begin{array}{l}\% \mathrm{so}^{\mathrm{b}} \\
\mathrm{A}--\mathrm{C}\end{array}$ & $\begin{array}{l}\text { \% So } \\
\text { C--A }\end{array}$ & $\%_{H}^{E^{c}}$ & $\begin{array}{l}72_{\mathrm{P}}^{\mathrm{E}} \\
\end{array}$ \\
\hline \multirow[t]{3}{*}{$\begin{array}{r}3 \text { - Feed } 1 \\
\text { Mate } 1\end{array}$} & $\begin{array}{l}\text { Sperm } \\
\text { Embryos } \\
\text { (20 min) }\end{array}$ & $-\overline{1116}$ & $\begin{array}{l}17016 \\
10119\end{array}$ & $\begin{array}{l}18616 \\
19568\end{array}$ & $\begin{array}{l}2400 \\
1500\end{array}$ & 0.0015 & 0.83 & 20 & 68 \\
\hline & $\begin{array}{l}\text { Embryos } \\
(180 \mathrm{~min})\end{array}$ & 1128 & 10395 & 21732 & 1400 & & & & \\
\hline & $\begin{array}{l}\text { Embryos } \\
\text { ( } 3-12 \text { hrs) }\end{array}$ & -- & 10815 & 36348 & 1300 & & & & \\
\hline \multirow[t]{3}{*}{$\begin{array}{r}3 \text { - Feed } 2 \\
\text { Mate } 1\end{array}$} & $\begin{array}{l}\text { Sperm } \\
\text { Embryos } \\
\text { (20 min) }\end{array}$ & $-\overline{2243}$ & $\begin{array}{l}15370 \\
21730\end{array}$ & $\begin{array}{l}16495 \\
57216\end{array}$ & $\begin{array}{l}2000 \\
2486\end{array}$ & 0.0015 & 0.83 & 20 & 68 \\
\hline & $\begin{array}{l}\text { Embryos } \\
(180 \mathrm{~min})\end{array}$ & 2536 & 10022 & 32097 & 1100 & & & & \\
\hline & $\begin{array}{l}\text { Embryos } \\
(3-12 \text { hrs })\end{array}$ & -- & 10897 & 18634 & 1500 & & & & \\
\hline 4 - Mate 1 & $\begin{array}{l}\text { Sperm } \\
\text { Embryos } \\
\text { (15 min) }\end{array}$ & $-\overline{1478}$ & $\begin{array}{l}28495 \\
16600\end{array}$ & $\begin{array}{l}15223 \\
12448\end{array}$ & $\begin{array}{l}1950 \\
1200\end{array}$ & & & & \\
\hline
\end{tabular}


APPENDIX I (Continued)

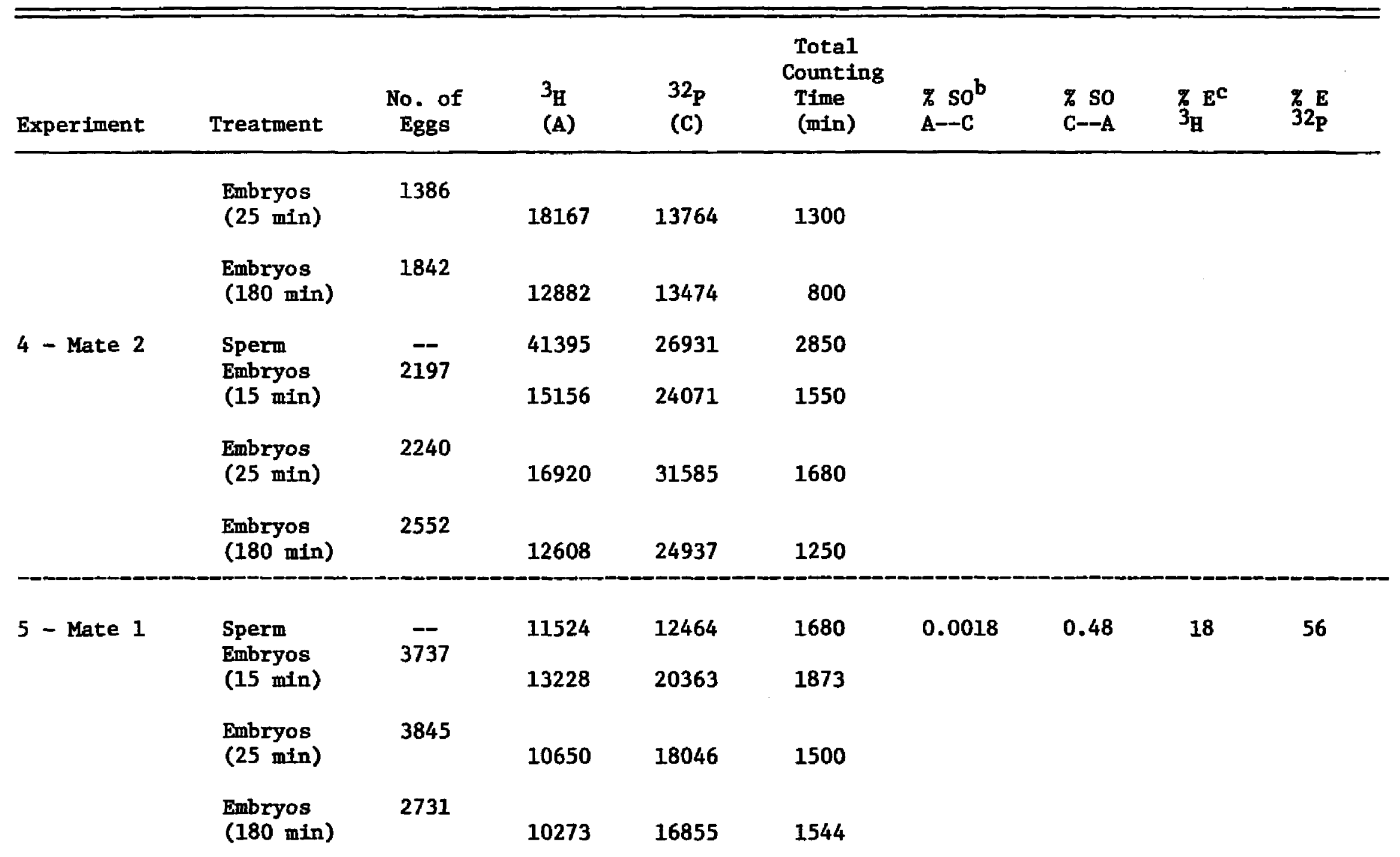


APPENDIX I (Continued)

\begin{tabular}{|c|c|c|c|c|c|c|c|c|c|}
\hline ExperIment & Treatment & $\begin{array}{l}\text { No. of } \\
\text { Eggs }\end{array}$ & $\begin{array}{l}3_{\mathrm{H}} \\
\text { (A) }\end{array}$ & $\begin{array}{l}32 p \\
\text { (C) }\end{array}$ & $\begin{array}{l}\text { Total } \\
\text { Counting } \\
\text { Time } \\
\text { (min) }\end{array}$ & $\begin{array}{l}\text { \% sob } \\
\mathrm{A}--\mathrm{C}\end{array}$ & $\begin{array}{l}\text { \% So } \\
\text { C--A }\end{array}$ & ${ }_{3 \mathrm{~B}}^{E^{c}}$ & $\begin{array}{l}7 \mathrm{E} \\
32 \mathrm{P}\end{array}$ \\
\hline \multirow[t]{2}{*}{5 - Mate 2} & $\begin{array}{l}\text { Sperm } \\
\text { Embryos } \\
\text { (25 min) }\end{array}$ & $\overline{2552}$ & $\begin{array}{l}11385 \\
10926\end{array}$ & $\begin{array}{l}13961 \\
19807\end{array}$ & $\begin{array}{l}1452 \\
1700\end{array}$ & 0.0018 & 0.48 & 18 & 56 \\
\hline & $\begin{array}{l}\text { Embryos } \\
\text { (180 min) }\end{array}$ & 2227 & 10715 & 20237 & 1642 & & & & \\
\hline \multirow[t]{2}{*}{$\begin{array}{c}6 \text { - Mate } 1 \\
\text { Day } 1\end{array}$} & $\begin{array}{l}\text { Sperm } \\
\text { Embryos } \\
\text { (15 min) }\end{array}$ & $\overline{1143}$ & $\begin{array}{c}18743 \\
12309\end{array}$ & $\begin{array}{l}10449 \\
10305\end{array}$ & $\begin{array}{l}1900 \\
1400\end{array}$ & 0.001 & 0.61 & 20 & 59 \\
\hline & $\begin{array}{l}\text { Embryos } \\
\text { (180 min) }\end{array}$ & 1205 & 13553 & 13044 & 1500 & & & & \\
\hline \multirow[t]{3}{*}{$\begin{array}{c}6 \text { - Mate } 1 \\
\text { Day } 2\end{array}$} & $\begin{array}{l}\text { Sperm } \\
\text { Embryos } \\
\text { (15 min) }\end{array}$ & $\overline{1220}$ & $\begin{array}{r}14019 \\
9225\end{array}$ & $\begin{array}{r}9598 \\
11501\end{array}$ & $\begin{array}{l}1200 \\
1124\end{array}$ & & & & \\
\hline & $\begin{array}{l}\text { Embryos } \\
\text { (30 min) }\end{array}$ & 2030 & 11526 & 13400 & 1400 & & & & \\
\hline & $\begin{array}{l}\text { Embryos } \\
\text { (180 min) }\end{array}$ & 1305 & 10726 & 13221 & 1300 & & & & \\
\hline
\end{tabular}


APPENDIX I (Continued)

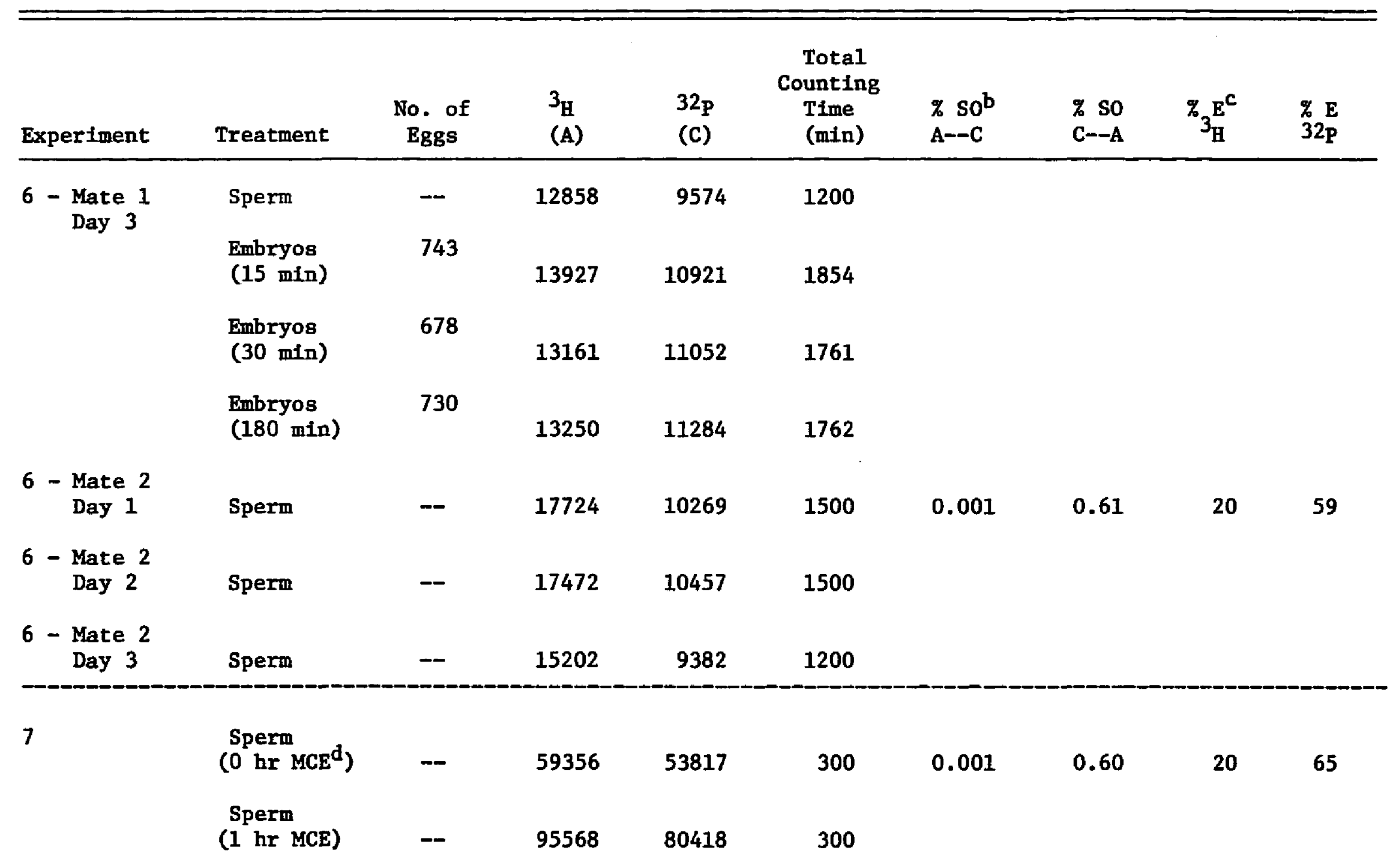


APPENDIX I (Continued)

\begin{tabular}{|c|c|c|c|c|c|c|c|c|c|}
\hline Experiment & Treatment & $\begin{array}{r}\text { No. of } \\
\text { Eggs }\end{array}$ & $\begin{array}{l}{ }^{3} \mathrm{H} \\
(\mathrm{A})\end{array}$ & $\begin{array}{l}{ }^{32} \mathrm{P} \\
(\mathrm{C})\end{array}$ & $\begin{array}{l}\text { Total } \\
\text { Counting } \\
\text { Time } \\
\text { (min) }\end{array}$ & $\begin{array}{l}\mathrm{z} \mathrm{so}^{\mathrm{b}} \\
\mathrm{A}--\mathrm{C}\end{array}$ & $\begin{array}{l}\% \text { so } \\
\text { C--A }\end{array}$ & $\%_{{ }_{H}} E^{c}$ & $\begin{array}{l}\% \mathrm{E} \\
32 \mathrm{P}\end{array}$ \\
\hline & $\begin{array}{l}\text { Sperm } \\
\text { ( } 4 \mathrm{hr} \text { MCE })\end{array}$ & -- & 133112 & 112267 & 300 & & & & \\
\hline & $\begin{array}{l}\text { Embryos } \\
(30 \mathrm{~min} \\
0 \mathrm{hr} \text { MCE) }\end{array}$ & - & 45922 & 13699 & 800 & & & & \\
\hline & $\begin{array}{l}\text { Embryos } \\
\text { ( } 30 \mathrm{~min} \\
1 \mathrm{hr} \text { MCE) }\end{array}$ & - & 44000 & 13638 & 600 & & & & \\
\hline & $\begin{array}{l}\text { Embryos } \\
\text { (30 min } \\
4 \mathrm{hr} \text { MCE) }\end{array}$ & -- & 75909 & 22726 & 600 & & & & \\
\hline
\end{tabular}

a Spillover and efficiency values are the same for each sample in a given experiment and are presented only once with the data from each experiment.

b so stands for spillover of counts in one counting channel to the other channel.

C E stands for counting efficiency for a particular isotope.

d MCE stands for mercaptoethanol. 
APPENDIX II

TOTAL COUNTS AND COUNTING TIME

OF BLANKS FOR EXPERTMENTS ONE THROUGH SEVEN

\begin{tabular}{|c|c|c|c|c|}
\hline Experiment & Blank & ${ }^{3} \mathrm{H} \quad(\mathrm{A})$ & ${ }^{32} \mathrm{P}$ (c) & $\begin{array}{l}\text { Time } \\
\text { (min) }\end{array}$ \\
\hline \multirow[t]{2}{*}{1} & Sperm DNA & 8198 & 9400 & 1100 \\
\hline & Embryos DNA & 17830 & 16776 & 2100 \\
\hline 2 & Sperm DNA & 9109 & 10459 & 1200 \\
\hline \multirow[t]{2}{*}{3} & Sperm DNA & 14284 & 16406 & 2285 \\
\hline & Embryos DNA & 12993 & 15186 & 2100 \\
\hline \multirow[t]{2}{*}{4} & Sperm DNA & 14438 & 12163 & 1898 \\
\hline & Embryos DNA & 23223 & 19583 & 3052 \\
\hline \multirow[t]{2}{*}{5} & Sperm DNA & 11508 & 11630 & 1800 \\
\hline & Embryos DNA & 10849 & 11639 & 1800 \\
\hline 6 & Sperm DNA & 17422 & 10704 & 2400 \\
\hline \multirow[t]{2}{*}{7} & Sperm DNA & 22966 & 11285 & 2600 \\
\hline & Embryos DNA & 23491 & 11347 & 2600 \\
\hline
\end{tabular}


PLEASE NOTE:

Dissertation contains pages with small and indistinct print. Filmed as received. UNI VERSITY MICROFILMS 


\section{APPENDIX III}

\section{PUBLICATIONS OF FRANR CHARLES JANCA}

Ficsor, G., Janca, F.C., and Van Hook, C. (1970) Tests for mutagenicity using Nitrosoguanidine, .DDT and captan in maize, Newsletter of the Environmental Mutagen Soclety, No. 3:38 (Abstract).

Ficsor, G., Beyer, R.D., Janca, F.C., and Zimmer, D.M. (1971) An organspecific host-mediated microblal assay for detecting chemical mutagens in vivo: Demonstration of mutagenic action in rat testes following streptozoticin treatment, Mutation Res., 13:283-287.

Janca, F.C. (1972) N-methyl-n'-nitro-N-nitrosoguanidine indiced dominant and recessive mutations in Zea mays, Masters Thesis, Graduate College, Western Michigan UnIversity, Kalamzaoo, Mi.

Aaron, C.S., Lee, W.R., Janca, F.C. and Seamster, P.M..(1973) Ethylation of DNA In the germ line of male Drosophila melanogaster, Proceedings of the Thirteenth International Congress of Genetics, Berkeley, California, Genetics, 74:1s (Abstract).

Lee, W.R., Aaron, C.S., and Janca, F.C. (1973) Dependence of alkylation and mutagenesis on germ cell stage, First International Conference on Environmental Mutagens, Astlomar, Pacific Grove, California (U.S.A.), Mutation Res., 21:226 (Abstract).

*Aaron, C.S., Lee, W.R., Seamster, P.M. and Janca, F.C. (1977) A nonaqueous gas exposure technique for microliter quantitles of chemical mutagens, Drosophila Information Service, 52:174-175.

Janca, F.C., Lee, W.R., and Aaron, C.S., (1977) Stab1lity of Induced DNA alkylations in sperm and embryos of Drosophila melanogaster. Eighth Annual Meeting of the Environmental Mutagen Society, Colorado Springs, Colorado. I presented this paper at the Annual Meeting of the Environmental Mutagen Society.

Lee, W.R., Aaron, C.S., Janca, F.C., and Skinner, P.M., (1977) Linear relation of alkylation to mutation in Drosophila. Second International Conference on Environmental Mutagens, Edinburgh, Scotland, Abstract Book p. 105.

\footnotetext{
*Included as part of this dissertation with the permission of the
} authors. 
Mron, C.S., W.R. Lee, P.M, Seamster and F. Janca, Louislana State University, Baton Rauge. A non-aqueous gas exposure technique for microliter quantities of chemical mutagens. titieg of the mutagen is advantageous with specifically radfolabeled mutagens because of the expense of these compounds.

Vacuum injection of flles was previously described using aqueous solutions (Sega and Lee, DIS 45,179 ) but for reactive mutagens an aqueous solution may be undesirable. Furthermore, the maximum exposure concentration of a compound in the aqueous based vacuum infection procedure is 1 Imited to the compound s solubility in water times the maximum concentration of water that can be achleved in the treatment flask ( 1 Imited by the dewpoint). It is more desirable to use true vapor of the mutagen if it is sufficlently volatile; therefore, we have developed a non-aqueous method of vacuum infection using glass fiber filter discs impregnated with the mutagen. For Instance, when using ethyl methanesulfonate (EMS), we dissolve the mutagen in ethyl ether, place the filter disc in the ether at the bottom of a shell vial and carefully evaporate the ether in stream of dry nitrogen thereby coating the glass filter with nutagen. We then place this filter in the vacuun relesse ilne of a special treatment apparatus (described hete), thus entraining the mutagen in the alr which fills the apparatus. (NotE: Due to the extreme toxicity of ether to flies, partfcularly under vacuum injection conditions, it is imperative that no ether remain on the fliter.)

The apparatus which we have developed is

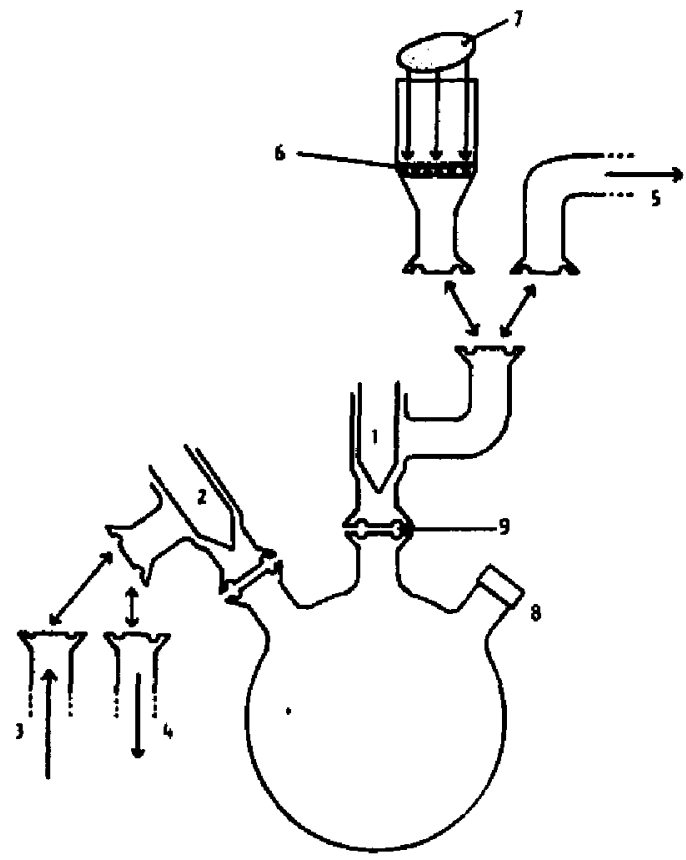
dlagranmed in Flgure 1 . The equipment uged consists of a treatment vessel, high vacuum seal valves, a intered glass funnel, and 0 ring seal joints as well as necessary traps and connections to vacuum pump, eir line, etc. The

Figure 1, Vacuum injection apparatus, 1) Valve (1; 2) Valve 2; 3) Alr or $\mathrm{N}_{2}$ inlet; 4) Vacuum line connection; 5) Alr or $\mathrm{N}_{2}$ outlet (to approprlate traps); 6) Sintered glass support funnel, 7) Gless fiber filter disc, impregnated with mutagen; 8) Septum for obtalning gas samples for gas chromatographic analysis. All joints $(e .8 ., 9)$ are " 0 " ring reali dimensions are selected to present minimum area of contact between vapor and potentially absorbent materials. E1ther 3 or 4 may be connected to 2 , and $11 \mathrm{ke}-$ wise ofther 5 or 6 may be connected to 1 . Operation is described in the text.

treatment vessel is a modifled $250 \mathrm{ml}, 3$ necked round bottomed flask. One neck was removed and replaced with a septum holder for collecting samples for gas chromatography. The other 2 necks have $0-r$ ing seal jolnts. The high vacuum seal valves (Kontes glass K-826515-0008 Kel-f

seals) are fftted with $0-r i n g$ seal joints (Kontes K-671750-0007). The sintered glass funnel (Byrex No. 416320, $15 \mathrm{mn}$ Medium grain) is fitted with an 0-ring seal jolnt.

At the start of an experiment the flles are anesthetized with $\mathrm{N}_{2}$ and shaken into the treatment vessel. The mutagen $1 \mathrm{~s}$ impregnated into a small round plece (the standard size 14 corkborer is a satisfactory diameter) of glass fiber filter (Geiman Type $A$, \#61701) and placed on the sintered glass funnel which is mounted on the port of the \#1 valve. Then, with with $\$ 1$ valve closed, a vacuun is pulled on the vessel ( $\sim 10 \mathrm{~mm} \mathrm{Hg}$ ) using Valve $\$ 2$. Valve $\| 2$ is closed and by opening Valve $\$ 1$ the vacuum is released through the funnel, thus evaporating 
and entraintug the chemical th the ats atream. Valve 11 is ageln cloned and the expoute Is continued for a period of time $(2-8 \mathrm{hra})$. At the end of the treatment time, compreased alr 1s adnltted through Valve 12 , out Valve 1 and subsequently through traps to fluah out the syatem and destroy any remalning urtugen. Mitrogen flow in the one path (1nto valve 12 , through the Elagk, out Valve $\$ 1$ ) lo used to anesthetize the flles for temoval from the vesos. In view of the extremely haxurdous nature of radlolabeled mutagens, great care must be taken to etisure the safety of laboratory personnel. The entire apparatus previously deacribed should be contelned whin a glove box or fune hood. Alkaline matcaptoacetate oolution (Lew1s and Bacher, DIs 43:193) 1s used as a chemlcal trap for Bis In our laboratory. It additlon, molecular aleve and cold traps are necesgery to avold radlochemical contanination of other equipment ouch as the vaculim pump.

The mathod described hate ha baen used to induce a $6 \%$ sax-11tiked recese Ive lathal ftequency by treating 50 of wh $2.0 \mathrm{mg}$ of bys for 8 hours. In a varate experiment 0.2 us of radlolabeled EMS wa adminlstered to 1,000 males with algnificant alkylation of DAh observed (Jance, F.C., W.R. Lee and C.8. Mron, unpublished).

Due to the varlability in lmpregnation of the filter disc with the mutagen, reproduclbility of this method of adainlatering mutagens is not oufflclent for constructing dosage responge curves; however, this is the most economical mothod we have for treating a large number of males with smil quantitied of radlolebeled tategens.

Acknowledgement, Support for thls atudy was provided by USPHS Grant 8s00320-09 and thoh Grant AT- (40-1)-3728. 
Frank Charles Janca was born on October 27, 1946 in Oak Park, Illinols and is the eldest of three children born to August and E1la Janca. Shortly after his birth his parents purchased a farm and moved to the rural community of Decatur in south western Michigan.

His early elementary schooling from Kindergarten to sixth grade was spent In a one-room country school (East Decatur Public School No. 5) where he and the other nelghborhood children were loved and taught by one of the most marvelous educators, Miss Mabel Schunaman. He attended Junfor High School at Decatur Consolidated Public Schools and in June 1964 was among the first class to graduate from the newly constructed Decatur Jr-Sr High School.

In September of 1964 he entered Western MichIgan University in Kalamazoo, Michigan and in 1968 he was graduated from that Institution with the Degree of Bachelor of Arts. During the fall of 1968 he was admitted to the Graduate Program in the Department of Zoology at WMU where he worked under the tutelage of Dr. Gyula Ficsor. In December of 1972 he recelved his Master of Arts Degree from WMU for work Involving the investigation of the mutagenicity of $\mathrm{N}-$ methyl-N'-n1tro-N-nitrosoguanidine in Zea mays. He came to Loulsiana State University in the fall of 1971 to continue his graduate studies in genetics and mutagenesis under the guidance of $\mathrm{Dr}$. William R. Lee. While attending Graduate School he gained valuable teaching and research experience by working as a teaching assistant and research assistant at WMU and LSU. 
The work presented here is in partial fulfillment for the Degree of Doctor of Philosophy In Zoology and was completed by May 1978. 
EXAMINATION AND THESIS REPORT

Candidate: Frank Charles Janca

Major Field: Zoology

Title of Thesis: Stability of Induced DNA alkylation In sperm and embryos of Drosophila melanogagter.

Approved:
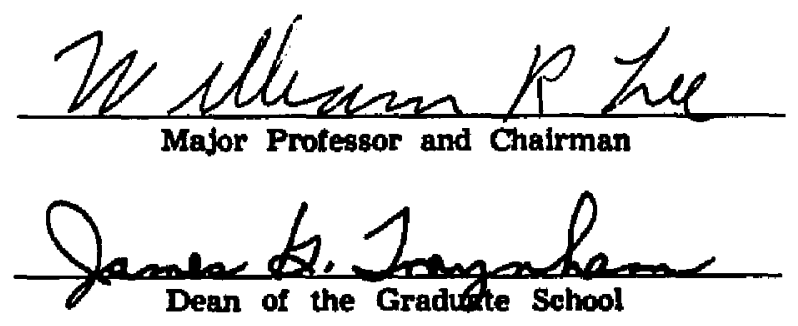

EXAMINING COMMITTEE:
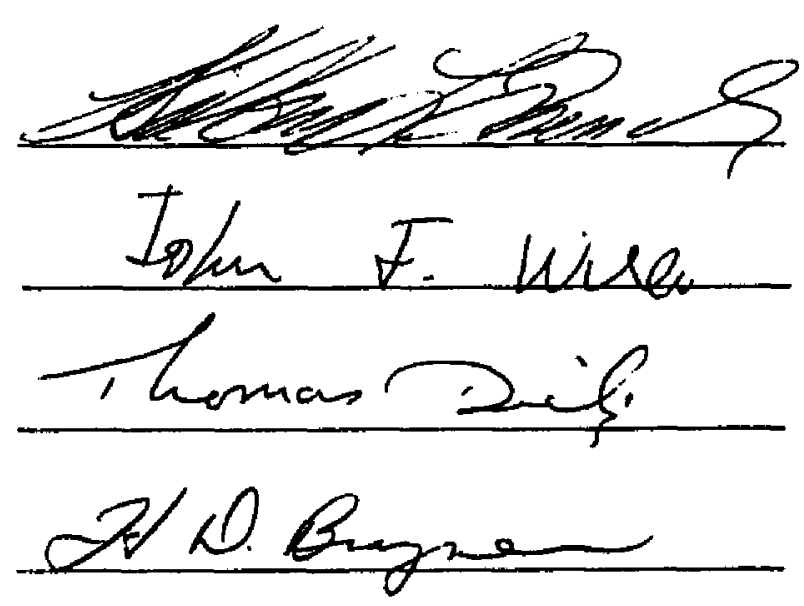

Date of Examination:

Af oil 27, 1938 